\title{
WestVirginiaUniversity
}

THE RESEARCH REPOSITORY @ WVU

Graduate Theses, Dissertations, and Problem Reports

2000

\section{Foodborne pathogens in poultry production and post-harvest control}

\author{
Rajesh R. Nayak \\ West Virginia University
}

Follow this and additional works at: https://researchrepository.wvu.edu/etd

\section{Recommended Citation}

Nayak, Rajesh R., "Foodborne pathogens in poultry production and post-harvest control" (2000). Graduate Theses, Dissertations, and Problem Reports. 1179.

https://researchrepository.wvu.edu/etd/1179

This Dissertation is protected by copyright and/or related rights. It has been brought to you by the The Research Repository @ WVU with permission from the rights-holder(s). You are free to use this Dissertation in any way that is permitted by the copyright and related rights legislation that applies to your use. For other uses you must obtain permission from the rights-holder(s) directly, unless additional rights are indicated by a Creative Commons license in the record and/ or on the work itself. This Dissertation has been accepted for inclusion in WVU Graduate Theses, Dissertations, and Problem Reports collection by an authorized administrator of The Research Repository @ WVU.

For more information, please contact researchrepository@mail.wvu.edu. 
Foodborne Pathogens in Poultry Production and Post-harvest Control

Rajesh R. Nayak

Dissertation submitted to the

College of Agriculture, Forestry, and Consumer Sciences

at West Virginia University

in partial fulfillment of the requirements

for the degree of

Doctor of Philosophy

In

Animal and Food Sciences

P. Brett Kenney, Ph.D., Chair Gary Bissonnette, Ph.D.

Mary Head, Ph.D., R.D.

Ronald Peterson, Ph.D.

Casey Ritz, Ph.D.

Division of Animal and Veterinary Sciences

Morgantown, West Virginia

2000

Keywords: Salmonella, zinc chloride, E. coli, poultry, foodborne, pathogens Copyright 2000 Rajesh R. Nayak 


\section{ABSTRACT \\ Foodborne pathogens in poultry production and post-harvest control}

\section{Rajesh R. Nayak}

A comprehensive ecological survey was conducted from April 1997 to June 1999 on four turkey flocks (F5-F8) to identify the preharvest sources of Salmonella colonization. Generic E. coli and total coliforms were enumerated as indicators of fecal contamination in F7 and F8. Turkey cecal and crop contents, litter, drinkers, air, feed, feeder contents, and environmental swabs were sampled and tested for Salmonella and E. coli. Salmonella was isolated from 13\% of litter, $11 \%$ of turkey ceca, $10 \%$ of drinkers, and $5 \%$ of swabs. Escherichia coli and total coliforms were detected in 45 and $53 \%$ of samples, respectively. Salmonella heidelberg was the major serotype isolated from the sampled flocks. About $25 \%$ of the Salmonella isolates were resistant to antibiotic(s). Identifying preharvest sources of Salmonella and E. coli colonization would assist integrators and producers in designing hazard analysis and critical control point (HACCP) protocols. On-farm reduction of these pathogens will assist processors in reducing positive carcasses at the plant.

A skin attachment model was used to examine the ability of $\mathrm{ZnCl}_{2}$ to reverse or inhibit Salmonella attachment to broiler skin. In reversal experiments, skin samples were first treated with $1 \mathrm{~mL}$ of $S$. typhimurium culture $\left(10^{8} \mathrm{CFU} / \mathrm{mL}\right)$ for $30 \mathrm{~min}$, followed by the addition of $1 \mathrm{~mL}$ of 25 or $50 \mathrm{mM} \mathrm{ZnCl}_{2}$ for 5 or $15 \mathrm{~min}$. For inhibition experiments, this order was reversed. "Firmly" and "loosely" attached salmonellae were enumerated on the skin. Treated skin samples were observed under a scanning electron microscope. In reversal experiments, 25 and $50 \mathrm{mM}$ $\mathrm{ZnCl}_{2}$ reduced ( $\mathrm{p}<0.01$ ) "firmly" attached cells by 77 and $89 \%$, respectively, when compared to the control (water). At 25 and $50 \mathrm{mM}$ concentration, $\mathrm{ZnCl}_{2}$ reduced ( $\mathrm{p}<0.0001$ ) cells in the "discard" by 99.4 and $99.9 \%$, respectively. Micrographs indicated that 25 and $50 \mathrm{mM} \mathrm{ZnCl}_{2}$ reduced $(\mathrm{p}<0.1)$ Salmonella attachment by 69 and $99.9 \%$, respectively, in the reversal

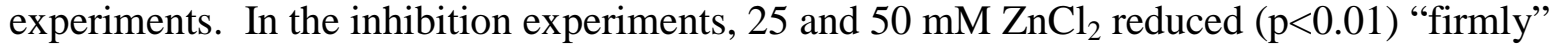
attached cells by 82 and $91 \%$, respectively. Reduction of Salmonella may be attributed, in part, to the bactericidal activity of $\mathrm{ZnCl}_{2}$ in addition to detachment of the bacterial cells on skin. 
Dedicated to my parents

and in the loving memory of Amma, Attya and Chacha 


\section{ACKNOWLEDGEMENTS}

I would like to express my sincerest gratitude to my mentor, Dr. P. Brett Kenney, for his professional guidance, inspiration, encouragement, and allowing me to work independently during my Ph.D. program. I would like to thank my committee members Drs. Gary Bissonnette, Mary Head, Ron Peterson, and Casey Ritz for their suggestions and constructive criticisms. I thank Drs. Charles Benson and Donald Munro at the Salmonella Reference Center, University of Pennsylvania, for serotyping Salmonella isolates and identifying the antibiotic resistance profile. I also thank Tom Basden and Dr. Alan Sexstone for their useful comments in writing the manuscripts. I gratefully acknowledge the technical support offered by Diane Berry, Dr. Jyoti Keswani, and Susan Slider. Help offered by Chestina Barr and Mark Satterfield at the Wardensville farm is greatly appreciated. I thank the faculty and fellow graduate students of the Division of Animal and Veterinary Sciences for their support and encouragement. I gratefully acknowledge the support of British United Turkey of America in this research.

I would like to thank my parents, Shobha and Ramesh, and my brother, Shrinivas, for their love, support, and encouragement. I will always be indebted to my parents for all the sacrifices they made for me. 


\section{TABLE OF CONTENTS}

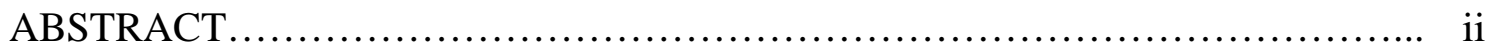

ACKNOWLEDGEMENTS .................................................... iv

TABLE OF CONTENTS ................................................... v

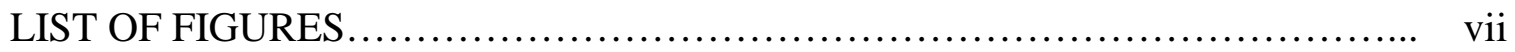

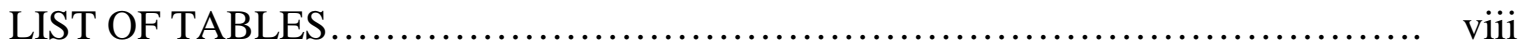

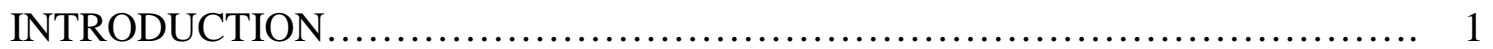

\section{REVIEW OF LITERATURE}

Salmonella profile............................................. 5

Colonization of Salmonella in poultry.......................... 8

Control of Salmonella during live production.................... 14

Control of Salmonella during processing........................ 20

Salmonella attachment to poultry skin/carcasses................... 24

Significance of Escherichia coli as an indicator organism........... 28

Consumer food safety...................................... 30

Concluding remarks........................................... 33

References............................................... 35

CHAPTER 1 Dynamics of Salmonella colonization in a turkey production facililty

Abstract...................................................... 60

Introduction.................................................... 62

Materials and Methods

Production parameters..................................... 63

Sampling procedures.................................... 65

Laboratory procedures................................ 68

Results and Discussion

Frequency of detection................................. 70

Distribution of serotypes.............................. 73

Antibiotic resistance profile............................... $\quad 76$

Effect of litter $\mathrm{pH}$ and water activity..................... 77

Effect of environmental conditions.......................... 79

Sex effect............................................. 81

Conclusions....................................................... 81

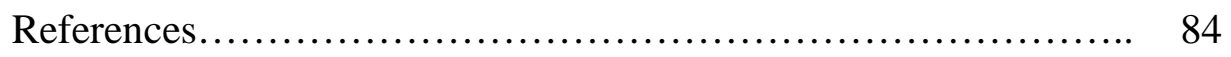


Appendices

Farm biosecurity measures.............................. 119

Turkey house cleaning and disinfection methods............. 120

Salmonella isolation procedure......................... 122

Sampled pens.......................................... 123

Bird density and mortality data......................... 124

CHAPTER 2 Non-pathogenic Escherichia coli and total coliforms as indicators of fecal contamination in a turkey production facililty

Abstract................................................... 126

Introduction............................................... 127

Materials and Methods

Sampling procedures.................................. 129

Laboratory procedures................................ 130

Results and Discussion...................................... 131

Conclusions................................................. 134

References................................................... 135

Appendix

Instructions for using $3 \mathrm{M}$ Petrifilm ${ }^{\mathrm{TM}}$ E. coli/coliform plates.. 143

CHAPTER 3 Inhibition and reversal of Salmonella typhimurium attachment to poultry skin using zinc chloride

Abstract..................................................... 148

Introduction.................................................. 150

Materials and Methods

Salmonella culture..................................... 151

Skin preparation.................................... 152

Skin model experiments............................. 153

Scanning electron microscopy........................ 155

Experimental Design........................................ 155

Results and Discussion

Reversal experiments............................... 156

Inhibition experiments................................ 157

Effect of $\mathrm{ZnCl}_{2}$ in Salmonella suspension.................. 157

Scanning electron microscopic studies.................... 159

Conclusions.............................................. 161

References................................................... 163

Appendices

Reversal experiment flow diagram..................... 178

Inhibition experiment flow diagram..................... 179

Statistical program................................. 180 


\section{LIST OF FIGURES}

\section{LITERATURE REVIEW}

Figure 1 An overview of the movement of Salmonella through the poultry chain (adapted from International Hatchery Practice and International Poultry Production Supplement). Arrows indicate Salmonella movement; $\mathrm{D}=$ disinfection; $\mathrm{H}=$ heat treatment; $\mathrm{M}=$ monitoring; $\mathrm{A}=$ acidification; $\mathrm{V}=$ vaccination; $\mathrm{Ve}=$ vaccination of egg layers only; $\mathrm{T}=$ test (if positive reject or reschedule); and $\mathrm{CE}=$ competitive exclusion.

Figure 2 Critical control points for whole carcasses processing in the control of poultry salmonellosis

\section{CHAPTER 1}

Figure 1 Turkey production facility.

Figure 2 Maximum and minimum temperatures and percent relative humidity inside the turkey production facility in flock 6 .

Figure 3 Maximum and minimum temperatures and percent relative humidity inside the turkey production facility in flock 7 ....

Figure 4 Maximum and minimum temperatures and percent relative humidity inside the turkey production facility in flock 8 .

Figure 5 Prevalence of Salmonella in male and females turkeys from various flock 5 sources in the turkey production facility....

\section{CHAPTER 3}

Figure 1 Schematic diagram of a skin attachment model

Figure 2 Salmonella typhimurium cell suspension $\left(10^{7} \mathrm{CFU} / \mathrm{mL}\right)$ mixed with (a) control; (b) $25 \mathrm{mM} \mathrm{ZnCl}$; and (c) $50 \mathrm{mM} \mathrm{ZnCl}_{2}$ and held for $15 \mathrm{~min}$ at room temperature $\left(\sim 22^{\circ} \mathrm{C}\right)(1000 \mathrm{X})$.

Figure 3 Scanning electron micrographs of chicken skin samples from reversal experiments: (a) control, $5 \mathrm{~min}$; (b) $25 \mathrm{mM} \mathrm{ZnCl}_{2}, 5 \mathrm{~min}$; (c) $50 \mathrm{mM}$ $\mathrm{ZnCl}_{2}$, $5 \mathrm{~min}$; (d) control, $15 \mathrm{~min}$; (e) $25 \mathrm{mM} \mathrm{ZnCl}_{2}, 15 \mathrm{~min}$; and (f) 50 $\mathrm{mM} \mathrm{ZnCl} 2,15 \min ($ bar $10 \mu)$

Figure 4 Scanning electron micrographs of chicken skin samples from inhibition experiments: (a) control, $5 \mathrm{~min}$; (b) $25 \mathrm{mM} \mathrm{ZnCl}_{2}, 5 \mathrm{~min}$; (c) $50 \mathrm{mM}$ $\mathrm{ZnCl}_{2}$, $5 \mathrm{~min}$; (d) control, $15 \mathrm{~min}$; (e) $25 \mathrm{mM} \mathrm{ZnCl} 2,15 \mathrm{~min}$; and (f) 50 $\mathrm{ZnCl}_{2}, 15 \min ($ bar $10 \mu)$ 


\section{LIST OF TABLES}

\section{LITERATURE REVIEW}

Table $1 \quad$ Salmonella virulent factors and their mechanisms of action.............. 51

Table 2 Sources of Salmonella (and other microorganisms) contamination during poultry processing.

Table 3 Salmonella-reduction performance standards in the U.S. poultry slaughter plants...

Table 4 Escherichia coli control testing criteria in U.S. processing plants 54

\section{$\underline{\text { CHAPTER } 1}$}

Table 1 Characteristics of turkey flocks sampled during the survey............ 88

Table 2 Pen assignments for the sampled flocks. ........................... 89

Table 3 Dietary specifications of the British United Turkeys of America feeding program used for Flock 6 .

Table 4 Dietary specifications of the British United Turkeys of America feeding

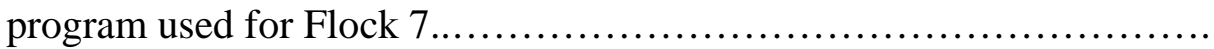

Table 5 Dietary specifications of the British United Turkeys of America feeding program used for Flock 8

Table 6 Frequency of Salmonella detected from various flock 5 samples in the turkey production facility.

Table 7 Frequency of Salmonella detected from various flock 6 samples in the turkey production facility

Table 8 Frequency of Salmonella detected from various flock 7 samples in the turkey production facility.

Table 9 Frequency of Salmonella detected from various flock 8 samples in the turkey production facility

Table 10 Distribution of Salmonella serotypes isolated from various samples in the turkey production facility.

Table 11 Distribution of Salmonella serotypes isolated from various flock 5 samples in the turkey production facility 
Table 12 Distribution of Salmonella serotypes isolated from various flock 6 samples in the turkey production facility............................ 99

Table 13 Frequency of antibiotic resistant Salmonella serotypes isolated from various samples in the turkey production facility in the sampled flocks... 100

Table 14 Antibiotic resistance among Salmonella serotypes isolated from various flock 5 samples in the turkey production facility

Table 15 Antibiotic resistance among Salmonella serotypes isolated from various flock 6 samples in the turkey production facility.................... 102

Table 16 Antibiotic resistance among Salmonella serotypes isolated from various flock 8 samples in the turkey production facility

Table 17 Litter $\mathrm{pH}$ and Aw measurements from pens sampled during the growout of flock 5

Table 18 Litter $\mathrm{pH}$ and Aw measurements from pens sampled during the growout of flock 6

Table 19 Litter $\mathrm{pH}$ and Aw measurements from pens sampled during the growout of flock 7

Table 20 Litter $\mathrm{pH}$ and Aw measurements from pens sampled during the growout of flock 8 .

\section{CHAPTER 2}

Table 1 Summary of turkey flock statistics.

Table 2 Frequency and enumeration of generic E. coli detected in flock 7 from various samples in the turkey production facility during the grow-out period.

Table 3 Frequency and enumeration of generic E. coli detected in flock 8 from various samples in the turkey production facility during the grow-out period.....

Table $4 \quad$ Frequency and enumeration of total coliforms detected in flock 7 from various samples in the turkey production facility during the grow-out period 
Table 5 Frequency and enumeration of total coliforms detected in flock 8 from various samples in the turkey production facility during the grow-out

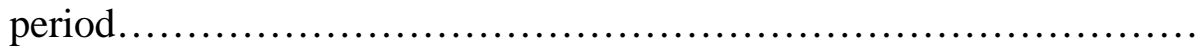

\section{CHAPTER 3}

Table 1 Effect of $\mathrm{ZnCl}_{2}$ on "discard" $\mathrm{pH}$ and Salmonella typhimurium attachment to chicken skin in the reversal experiments................. 166 


\section{INTRODUCTION}

Fresh and processed foods have been implicated in transmitting more than 200 diseases among humans (Mead et al., 1999). The Center for Disease Control (CDC) and Prevention estimates that foodborne diseases cause approximately 76 million illnesses, 325,000 hospitalizations, and 5,000 deaths in the United States each year (Mead et al., 1999). Of these, nearly 14 million illnesses, 60,000 hospitalizations, and 1,800 deaths are caused by known pathogens. Bacteria such as Campylobacter, Salmonella (non-typhoid), Escherichia coli O157:H7, Listeria monocytogenes, and Vibrio spp. have been implicated in several foodborne outbreaks. In addition, parasites such as Cryptosporidium parvum, Cyclospora, Giardia lambia, Toxoplasma gondii, and Trichinella spiralis, and viruses such as Hepatitis A and Norwalk-like viruses have been implicated in food-related outbreaks (Mead et al., 1999).

Foodborne diseases cause more illnesses but fewer deaths than previously estimated. Outbreaks have been attributed to factors such as demographics and lifestyles, human behavior, changes in industry and technology, changes in travel and commerce, the shift towards global economy, microbial adaptation, breakdown in the public health infrastructure, and the lack of knowledge on food safety and handling practices (Knabel, 1995; Altekruse et al., 1997; Hall, 1997). Foodborne illnesses have incurred medical and productivity costs of $\$ 8$ to 23 billion/year to the U.S. economy (Hedberg et al., 1994). Addressing emerging foodborne diseases will require sensitive and rapid surveillance, enhanced laboratory methods of identification and subtyping, and effective prevention and control of pathogens.

The CDC report estimates 1.3 million cases of non-typhoidal Salmonella-related illnessness ( $9.7 \%$ of the total foodborne illnesses), 15,600 hospitalizations (25.6\% of the total), and 553 deaths (30.6\% of the total) in the U.S. each year (Mead et al., 1999). Food vehicles 
associated with these outbreaks include chicken, turkey, beef, pork, eggs, milk, and dairy products, (Tietjen and Fung, 1995). Poultry consumption has increased dramatically in the U.S. over last the two decades. In 1993, over 7.5 billion fertile eggs were hatched and about 6.5 billion broilers were produced in the U.S. (NACMCF, 1997). In 1991, broiler consumption per person was $29 \mathrm{~kg}$ and turkey and ready-to-cook chicken was $9 \mathrm{~kg}$, a total of $38 \mathrm{~kg}$ of poultry consumed per person. Increased poultry consumption has increased poultry-associated foodborne diseases, particularly salmonellosis, caused by Salmonella.

Contamination of poultry with Salmonella occurs prior to entry into the processing facility and by cross-contamination in the processing plants. It is difficult to improve the microbiological quality of chickens in the processing areas. Several physical and chemical decontamination procedures have been applied to poultry carcasses in an attempt to reduce and/or eliminate Salmonella contamination. However, these procedures have not been completely successful in eliminating Salmonella. Hence, it is necessary to develop new methods to eliminate the pathogen from poultry carcasses. In order to achieve this objective, a clearer understanding of the mechanism of Salmonella attachment to poultry skin/tissue is necessary. To achieve a significant reduction in the level of Salmonella contamination among broiler carcasses, Salmonella-free chickens must be delivered at the processing plants. A reduction of Salmonella on poultry carcasses necessitates comprehensive control at the farm where birds are brooded and raised before shipment to processing plants. Breeder flocks, hatcheries, contaminated feed and water, and environmental sources/vectors such as litter, humans, and insects are potential pre-harvest sources of Salmonella contamination in poultry (Jones et al., 1991; Bailey, 1993; Hoover et al., 1997). 
Knowledge of key preharvest factors responsible for Salmonella colonization would help integrators and poultry producers in defining critical, preharvest control points on the farm. Intervention at these points could reduce or eliminate horizontal transmission and Salmonellapositive birds arriving at the processing plants. Treatment of carcasses with novel chemicals can be useful in reducing the level and frequency of Salmonella on poultry carcasses at the processing plants. A combination of pre- and post-harvest intervention strategies can ultimately deliver Salmonella-free, fresh poultry to consumers, thereby significantly reducing the medical and productivity costs associated with salmonellosis. 


\section{REFERENCES}

Altekruse, S.F., Cohen, M.L. and Swerdlow, D.L. 1997. Emerging foodborne diseases. Emerg. Inf. Dis. 3:285-293.

Bailey, J.S. 1993. Control of Salmonella and Campylobacter in poultry production: A summary of work at Russell Research Center. Poultry Sci. 72:1169-1173.

Hall, R.L. 1997. Foodborne illnesses: Implications for the future. Emerg. Inf. Dis. 3:555-559.

Hedberg, C.W., MacDonald, K.L. and Osterholm, M.T. 1994. Changing epidemiology of foodborne disease: A Minnesota perspective. Clin. Infect. Dis. 18:671-682.

Hoover, N.J., Kenney, P.B., Amick, J-A. and Hypes, W.A. 1997. Preharvest sources of Salmonella colonization in turkey production. Poultry Sci. 76:1232-1238.

Jones, F.T., Axtell, R.C., Rives, R.V., Scheideler, S.E., Tarver, Jr. F.R., Walker, R.L. and Wineland, M.J. 1991. A survey of Salmonella contamination in modern broiler production. J. Food Prot. 54:502-507.

Knabel, S.J. 1995. Foodborne Illness: Role of home food handling practices. Food Technol. 49:119-131.

Mead, P.S., Slutsker, L., Dietz, V., McCaig, L.F., Bresee, J.S., Shapiro, C., Griffin, P.M. and R.V. Tauxe. 1999. Food-related illness and death in the United States. Emerg. Inf. Dis. 5:607625.

National Advisory Committee on Microbiological Criteria for Foods. 1997. Generic HACCP application in broiler slaughter and processing. J. Food Prot. 60:579-604.

Tietjen, M. and Fung, D.Y.C. 1995. Salmonellae and food safety. Crit. Rev. Microbiol. 21:5383. 


\section{REVIEW OF LITERATURE}

\section{Salmonella Profile}

\section{$\underline{\text { Characteristics }}$}

Salmonella spp. are facultative anaerobic, gram-negative rods belonging to the family Enterobacteriaceae (D’Aoust, 1997). Most members of this genus are motile with peritrichous flagella, except $S$. pullorum, S. gallinarum, and S. singapore which possess dysfunctional flagella. Salmonellae are chemoorgantotrophic and can metabolize nutrients by respiratory and fermentative pathways. These organisms grow optimally at $37^{\circ} \mathrm{C}$ (range 2 to $54^{\circ} \mathrm{C}$ ), $\mathrm{pH} 6.7$ to 7.5 (range 4.5 to 9.5 ), and water activity $\geq 0.93$. They can catabolize D-glucose and other carbohydrates producing acid and gas. Salmonellae are oxidase negative and catalase positive, grow on citrate as the sole carbon source, produce hydrogen sulfide, decarboxylates lysine and ornithine, and do not hydrolyze urea. These traits have been useful in the biochemical identification of this organism. Salmonella produces acid and gas from glucose in triple sugar iron (TSI) agar medium and does not utilize lactose or sucrose in TSI or in different plating media such as brilliant green, xylose lysine deoxycholate, xylose lysine tergitol, and Hektoen enteric agars. In addition, typical salmonellae produce an alkaline reaction from decarboxylation of lysine to cadaverine in lysine iron agar (LIA) and generate hydrogen sulfide gas in TSI and LIA media.

Over 2,000 serotypes of Salmonella have been identified (D’Aoust, 1997). Prevalence of Salmonella species as a biochemically homogeneous group of microorganisms has been rapidly diminishing. Biochemical identification of Salmonella isolates is coupled with serological confirmation involving agglutination of bacterial surface antigens with Salmonella-specific antibodies. These include O lipopolysaccharides (LPS) on the external surface of the bacterial 
outer membrane, $\mathrm{H}$ antigens associated with the peritrichous flagella, and the capsular (Vi) antigens found only in S. typhi, S. paratyphi C, and S. dublin (Le Minor, 1981).

\section{$\underline{\text { Reservoirs }}$}

Salmonella is ubiquitous in the natural environment, residing mostly in the gastrointestinal tract of warm and cold-blooded animals. Sources of infection include contaminated soil, vegetation, water, and components of animal feeds such as bone, meat and fish meal, particularly those containing milk-, meat-, or egg-derived constituents. Egg and poultry products remain the principal reservoir of Salmonella. In addition, beef, pork, and mutton are potential vehicles of Salmonella transmission (D'Aoust, 1997). Persistence of Salmonella in the poultry, beef, and pork industries originates from exposure of livestock to environmental sources of contamination, contaminated feeds, and by parental transmission. $\underline{\text { Disease characteristics and treatment }}$

Salmonella infections among humans can lead to several clinical symptoms such as enteric (typhoid) fever, uncomplicated enterocolitis, and systemic infections by non-typhoid microorganisms. The disease is usually self-limiting but may become systemic in young children and immunocompromised adults. Enteric fever can range from 7 to 28 days and may include diarrhea, prolonged or spiking fever, abdominal pain, and headache (D'Aoust, 1991). Treatments include supportive therapy and/or use of chloramphenicol, ampicillin or trimethoprim-sulfamethoxazole to eliminate the systemic infection. Non-typhoidal Salmonella results in enterocolitis that appears 8 to $72 \mathrm{~h}$ after contact with the invasive pathogen. Symptoms include abdominal pain and non-bloody diarrhea. Supportive therapy (fluid and electrolyte replacement) has been recommended for clinical cases of enterocolitis. Salmonella-induced chronic conditions such as aseptic reactive arthritis, Reiter's syndrome, and spondylitis have 
been reported (D'Aoust, 1997). Live attenuated vaccines induce strong and durable humoral and cell-mediated immunity.

$\underline{\text { Infectious dose (ID) }}$

The ID varies with the immune status of an individual. Newborns, infants, elderly, and immunocompromised individuals are more susceptible to Salmonella infections than are healthy adults. Generally, a large number of cells $\left(10^{6}-10^{11}\right)$ are required to cause an infection. However, studies have shown that 1-10 cells in cheddar cheese and chocolate can constitute a human ID (D’Aoust et al., 1985; Kapperud et al., 1990). High fat content has been the common denominator associated with low ID. Entrapment of Salmonella within hydrophobic lipid micelles may protect against bactericidal action of gastric acids (D'Aoust, 1997).

$\underline{\text { Pathogenicity and virulence factors }}$

The ability of Salmonella to cause human infection depends on the ability of the organism to attach (colonize) and enter (invade) intestinal columnar epithelial cells (enterocytes) and specialized M cells overlying Peyer's patches. Salmonella competes with the indigenous gut microflora for suitable attachment sites on the luminal surface of the intestinal cell wall and evades capture by secretory immunoglobin A present on the surface of epithelial cells (D'Aoust, 1997). Salmonella attaches to the enterocytes by type 1 (mannose-sensitive) or type 3 (mannoseresistant) fimbriae, surface adhesions, nonfimbriate (mannose-resistant) hemagglutinins or enterocyte-induced polypeptides with host (human) glycoprotein receptors located on the microvilli or glycocalyx of the intestinal surface (D’Aoust, 1991; Polotsky et al., 1994). Following attachment, Salmonella can produce one or more virulence factors that cause infection (Table 1). 


\section{Colonization of Salmonella in Poultry}

$\underline{\text { Avian salmonellosis }}$

Salmonella pullorum and S. gallinarum are responsible for pullorum disease and fowl typhoid, respectively. Both diseases are widespread, and unless precautionary measures are implemented to control the spread, mortality is high. Pullorum disease infects the ova of turkey and chickens and can be responsible for the vertical transmission of Salmonella. The embryo is infected when the egg is hatched, and the disease can spread by horizontal transmission in the hatchery. An acute septicemia may be responsible for high mortality. Treatment with antimicrobial agents (sulfonamides) reduces mortality in infected birds. Fowl typhoid is a septicemic or chronic disease similar to pullorum, except that mortality from typhoid occurs at any age (North and Bell, 1990). Although both diseases have been successfully eradicated in the U.S., other Salmonella serotypes have been responsible for causing salmonellosis in humans. A commensal relationship between Salmonella, excluding S. pullorum and S. gallinarum, and host (bird) makes it difficult to prevent colonization of this organism in the gastrointestinal tract (Bailey, 1988). Because the bird's health is not compromised by the organism, it would be accurate to report that chickens or turkeys are colonized, and not infected, with Salmonella. $\underline{\text { Sources and transmission }}$

There are several potential sources of Salmonella contamination in an integrated poultry operation (Hoover et al., 1997; Holder, 1998). Bird ceca, large intestine, and crop are the primary sites of Salmonella colonization (Fanelli et al., 1971; Snoeyenbos et al., 1982; McMeekin et al., 1984; Corrier et al., 1991; Bryan and Doyle, 1995; Hargis et al., 1995). Several factors affect the susceptibility of poultry to Salmonella colonization (Bailey, 1987). These factors include: (1) age of birds; (2) Salmonella serotype and initial challenge dose level; 
(3) stress - environmental, transport, and overt or subclinical disease; (4) feed additives antimicrobial and anticoccidials; (5) survival through gastric barrier; (6) competition with gut microflora; (7) location of a hospitable colonization site; and (8) host genetic background.

Day-old birds: Day-old chicks and poults are more susceptible to Salmonella colonization than are older birds. Milner and Shaffer (1952) demonstrated that $50 \%$ of day-old chicks were infected with an oral challenge of 10 cells of S. typhimurium. By day 14, however, a challenge dose of a million cells infected only $10 \%$ birds, indicating a marked increase in resistance with age. Mortality is normally high among chickens and turkeys during the first two weeks of the grow-out period (Williams, 1984). As birds age (2 weeks post-hatch), they offer greater resistance to natural Salmonella challenge due to development of a complex gut microflora (Barnes et al., 1972; 1980). Once the birds are colonized with Salmonella they become carriers and are capable of horizontally and vertically transmitting the organism within the flock and to other flocks as well. The severity of transmission will depend on the duration of exposure, sanitary conditions, and presence of other infectious agents in the breeding houses, hatcheries, and grow-out facilities.

Hatcheries and breeder flocks: In an integrated poultry operation, the hatchery takes eggs from broiler-breeder and distributes chicks to grow-out facilities. Thus, if one Salmonellapositive breeding flock exists, it could spread easily throughout the entire operation. Salmonella transmission may be compounded within the operation if poor hatchery management allows the organism to backtrack and colonize other breeding farms that supply eggs. Studies have shown that Salmonella serotypes found on fully processed broiler carcasses originate predominately from hatcheries and breeder flocks (Bhatia and McNabb, 1980; Lahellec and Colin, 1985). 
The U.S. poultry industry processes over 8 billion broiler-hatching eggs each year through commercial hatcheries (Cox, 1998). Salmonella rapidly penetrates the shell and membranes of a freshly laid egg and enters the interior of the egg via pores (Mayes and Takeballi, 1983). Existing conditions during incubation tend to favor the proliferation of these bacteria. Invading Salmonella do not cause extensive decomposition of the fertile egg and the chick hatches (Cason et al., 1994), resulting in the establishment of salmonellae reservoirs in commercial broiler operations and breeder hatcheries (Cox et al., 1990; 1991; Blankenship et al., 1993). Transmission of Salmonella has also been reported through direct ovarian shedding of the organism into the egg prior to addition of the cell membrane (Mayes and Takeballi, 1983). Ovarian contamination occurs when Salmonella passes from the alimentary canal to the ovaries via blood (Gordon and Tucker, 1965). Once Salmonella gets past the egg membranes, there are no effective means to eliminate or prevent further invasion into the egg and developing embryo (Cason et al., 1994). Entrapped Salmonella can be ingested by the chick as it emerges from the egg, and during hatching, can horizontally transmit Salmonella to other chicks. Bailey and coworkers (1992) demonstrated that a single egg contaminated with Salmonella may contaminate all eggs and newly hatched birds within a hatching cabinet.

Feed: Feed is a major source of Salmonella contamination in poultry flocks (Snoeyenbos et al., 1970; Dougherty, 1976; Cox et al., 1983; Hoover et al., 1997; McIlroy, 1998). Feed and feed ingredients such as animal proteins/by-products and vegetable proteins can provide an environment of suitable nutrients, moisture, $\mathrm{pH}$, and temperature for survival of Salmonella. Feed ingredients of animal (red meat) and vegetable origin, fishmeal, and poultry by-product meal are the major sources of feed contamination (Morris et al., 1969; Simmons and Byrnes, 1972; Cox et al., 1983; Rouse et al., 1988; Smith et al., 1989; Jones et al., 1991). Inadequate 
time-temperature control during pelleting, improper storage, and contamination during transportation can contribute to feed contamination with Salmonella prior to entering poultry houses (McCapes and Riemann, 1998). Feeder contents are also responsible for horizontal transmission of Salmonella within the poultry facilities (Dougherty, 1976; Hacking et al., 1978; Lahellec and Colin, 1985; Hoover et al., 1997).

Salmonella contamination of poultry feed can be controlled by consistently and effectively decontaminating feed and preventing recontamination at the production facilities. Control measures would include purchasing Salmonella-free feed ingredients and implementing stringent sanitary measures during feed production and transportation (Hoover, 1996). Organic acids (propionic and formic) and other chemicals (aldehydes, natural terpenes, and surfactants) control Salmonella recontamination in poultry feed (McIlroy, 1998). Feed pasteurization (65$70^{\circ} \mathrm{C}$ ) can be effective, but recontamination must be prevented in the post-heat manufacturing environment of the production facility. Irradiation of finished feed would be a promising decontamination technology for future consideration.

Litter: Poultry litter is a vector of Salmonella transmission in the grow-out facilities. Frequency and Salmonella serotype information on chicken carcasses can be assessed by examination of litter within poultry houses (Simmons and Byrnes, 1972). Litter can be contaminated by droppings of infected birds. Once the bird sheds Salmonella, litter can harbor the organism from a few days to several weeks. Litter, contaminated with Salmonella, can serve as a reliable indicator of flock contamination (Snoeyenbos et al., 1967; 1969; Olesiuk et al., 1969; Bhatia et al., 1979). Salmonella populations in litter are transient and heavy contamination would depend on recontamination from the intestine of the colonized bird. Fanelli and 
coworkers (1970) reported that recycling of Salmonella between litter and birds appears to maintain intestinal colonization.

Eventually, litter develops a Salmonella inhibitory effect (Tucker, 1967; Fanelli et al., 1970; Bhatia et al., 1979). Bactericidal activity of old litter was associated with a rapid increase in $\mathrm{pH}$ and ammonia compared to fresh litter (Snoeyenbos et al., 1967; Turnbull and Snoeyenbos, 1973; Opara et al., 1992). Older litter may assist young birds in development of complex gut microflora, excluding Salmonella by competition (Fanelli et al., 1970; Hoover, 1996). Several serotypes such as S. pullorum, S. gallinarum, S. typhimurium, and S. infantis were susceptible to the bactericidal effects of used litter (Botts et al., 1952; Snoeyenbos et al., 1967; Tucker, 1967; Fanelli et al., 1970; Olesiuk et al., 1971).

Water: Water is an important source/vector of Salmonella transmission (Gauger and Greaves, 1946; Bryan et al., 1968; Higgins et al., 1982; Morris et al., 1969; Stersky et al., 1981). Fecal contamination of drinking water by Salmonella-infected birds could result in rapid contamination of the poultry house. Water can be initially contaminated with Salmonella by bird feces, litter, feed, and dust or by residual contamination associated with drinkers (Poppe et al., 1986; Morgan-Jones, 1980). High levels of Salmonella $\left(10^{4} \mathrm{CFU} / \mathrm{mL}\right)$ have been found in the drinking water of young ( $<1$ week of age) poults and chicks (Poppe et al., 1986). Birds could consume $10^{5}$ salmonellae per day re-infecting themselves continuously. Lahellec and Colin (1985) found that $18 \%$ of drinker samples were contaminated with Salmonella in broiler flocks, and Hoover and coworkers (1997) reported that $64 \%$ of drinkers were Salmonella-positive in turkey flocks. Addition of chlorine and sanitizer to drinking water reduced Salmonella in broilers (Al-Chalaby et al., 1985; Poppe et al., 1986). Type of drinkers used in broiler 
production influenced the level of free available chlorine in chlorinated water and thus, the levels of Salmonella (Poppe et al., 1986).

Pests: Rodents, insects, birds, and wild animals have been implicated as sources and vectors of Salmonella in poultry houses (Jones and Twigg, 1976; Keymer et al., 1991; Nagaraja et al., 1991; Henzler and Opitz, 1992; Hoover, 1996; Amick-Morris, 1998; Wray and Davies, 1998). Rats and mice are the major sources/vectors of Salmonella, and they can act as carriers after consuming infected chicken manure. Mice can transmit paratyphoid infections in poultry (Nagaraja et al., 1991). Mice usually stay within close proximity to feed and nesting places and can carry Salmonella within the poultry facility. Rats, on the other hand, travel long distances and may transmit Salmonella from farm to farm. Salmonella transmission may be amplified by mice or rats defecation in feed troughs and floor beds and on egg collection belts. Contamination can spread throughout the poultry house by automated feeding, egg conveyors, and manure removal equipment (Wray and Davies, 1998). Infected wild birds spread Salmonella on farms and pastures where domestic animals may acquire infections. Infected seagulls transmit Salmonella to poultry houses (Reilly et al., 1981). Davies and Wray (1994) detected Salmonella in several species of wild birds near hatcheries and poultry processing units, and these birds could contaminate equipment left outside buildings. Darkling beetles, maggots, blowfly larvae, cockroaches, flies, and mealworm beetles have been implicated in mechanical transport of Salmonella in poultry houses (Greenburg et al., 1970; Jones et al., 1991; Baggessen et al., 1992; Bennett, 1993; Rivault et al., 1993; Davies and Wray, 1995; Amick-Morris, 1998; Wray and Davies, 1998).

Environmental sources: Transmission of Salmonella within poultry houses may result from air and dust particles (Baskerville et al., 1992). Movement of personnel and birds, flapping 
of wings, and improper ventilation can spread Salmonella and other microorganisms in poultry houses (Jones et al., 1984). Wathes and coworkers (1988) reported that transmission occurs by inhalation and ingestion of contaminated airborne particles. Reports indicate that Salmonella can be isolated from organs of chicks, hens, mice, and calves after exposing them to aerosols containing the organism (Clemmer et al., 1960; Wathes et al., 1988; Baskerville et al., 1992). Dust in the poultry houses originates from feed, litter, feces, and birds. Wray and Davies (1998) reported that dust particles within selected poultry houses were contaminated ( 8.5 to $220.4 \times 10^{2}$ CFU/L air) with microorganisms such as species of Streptococcus, Staphylococcus, and

\section{Salmonella.}

Other parameters: Management and husbandry practices, transportation, and uncontrollable environmental conditions such as temperature may stress poultry. This stress, in turn, could increase the potential for bird colonization (Bailey, 1988). Thaxton and coworkers (1971) found that day-old chicks reared at 29,24 , and $21^{\circ} \mathrm{C}$ increased mortality by 0,28 , and $78 \%$, respectively when infected with $S$. paratyphi. Soerjadi and coworkers (1979) found that day-old chicks held at 18 to $22^{\circ} \mathrm{C}$ were more susceptible to low and moderate challenges of $S$. typhimurim than chicks challenged and held at 32 to $36^{\circ} \mathrm{C}$. Broilers withdrawn from feed for several hours before slaughter, crowded into transport coups, deprived of water, and subjected to hot and cold environmental temperatures during transportation could shed Salmonella and thus, cross-contaminate birds prior to entry at the slaughter facility (Bailey, 1988).

\section{Control of Salmonella During Live Production}

The complexity of Salmonella colonization of poultry will require a multi-faceted, integrated approach to successfully reduce the incidences of this pathogen. An overview of the 
movement of Salmonella through the poultry chain and possible means of control during each step of production is illustrated in Fig. 1 (McCapes et al., 1991).

\section{Biosecurity and disinfection}

A comprehensive biosecurity program should consist of guidelines for location of farms and facilities (conceptual biosecurity), farm and fence layout (structural biosecurity), and movement of personnel and equipment, manufacture and distribution of feed, water sanitation, rodent and pest control, cleaning and disinfection procedures, monitoring procedures and disease surveillance (operational biosecurity) (Rosales and Jensen, 1998). These guidelines should be simple, cost effective, and reviewed periodically. Protocols should include (1) procedures for poultry house cleaning and disinfection (Appendix, Chapter 1); (2) requirements for decontamination of buildings before and after placement of each flock; (3) requirements for employment and contract growing; (4) restrictions to avoid contact with avian and animal species; (5) requirements for personnel hygiene and health status; (6) disposal procedures for dead birds and manure; (7) source verification of litter suppliers; and (8) steps for decontamination of transport vehicles.

Salmonellosis is a "management" disease since its control depends on controlling sources of Salmonella contamination and transmission. Producers must purchase day-old breeding stock from companies with stringent biosecurity practices and participation in programs approved by the National Poultry Improvement Program (NPIP). Poultry feed should be purchased from companies that can deliver Salmonella-free feed. Feed mills must implement effective control programs for raw material receipt, storage, grinding and mixing, pelleting, crumbling, cooling, storage and during transportation of finished feed. Feed should be adequately processed (82- 
$85^{\circ} \mathrm{C}$ for $10-12 \mathrm{~min}$ ) in pre-pelleting feed conditioners. Hazard analysis and critical control point (HACCP) protocols may be introduced in feed mills to reduce Salmonella.

A biosecurity program to reduce rodent access to feed and water within poultry houses should include appropriate house management and sanitation, professional inspections for rodent baiting and trapping, rodent proofing the facility, and eliminating grass, shrubs, broken equipment, and burrows inside and outside the facility. Feed spills should be removed regularly to avoid attracting wildlife. Insects can be controlled by maintaining stringent sanitary practices at the facility and through careful use of pesticides. Drinking water should be chlorinated (3-5 ppm residual chlorine) to prevent Salmonella transmission.

An effective biosecurity program can never be "set in stone," and must be continuously improved through revisions, updates, and periodic audits by federal agencies and other professionals. Workshops on biosecurity and sanitation protocols must be organized to educate managers, flock supervisors, contract growers, farm employees, vaccination and monitoring crews, veterinarians, and others involved with poultry operations. A biosecurity program should be complemented by the use of antibiotics, competitive exclusion products, feed additives to prevent recontamination, litter and water treatments, and vaccination.

\section{$\underline{\text { Use of Antibiotics }}$}

Antibiotics are added to poultry feed or water (100-200 ppm) for treatment of bacterial diseases (Stavric and D'Aoust, 1993). Williams (1985) reported that neomycin or oxytetracycline, alone and in combination, reduced the level and frequency of S. typhimurium in the intestines of broilers. On the other hand, feeding antibiotics such as a combination of lincomycin and ovaparacin, nitrofurazone, and a combination of nitrofurazone and novobiocin 
enhanced colonization of S. typhimurium, S. infantis, and S. enteritidis, respectively, in chickens (Glisson, 1998).

Widespread use of antibiotics in the poultry industry have resulted in the emergence of antibiotic resistant Salmonella isolates from farm animals and meat-derived products (Novick, 1981; Holmberg et al., 1984; Spika et al., 1987; Pacer et al. 1989; D’Aoust, 1997). Gast and Stevens (1988) found that administering kanamycin to chickens resulted in increased kanamycinresistant strains of S. arizonae. Salmonella typhimurium DT 104 has attracted attention from public health authorities in the U.S. due to several reported outbreaks associated with this strain (Anon, 1997; Benson and Munro, 1997). This serotype is resistant to a wide range of antibiotics such as ampicillin, chloramphenicol, streptomycin, sulfonamides, tetracyclines, trimethoprim, and ciprofloxacin (Threfall et al., 1997). Salmonella typhimurium DT 104 can withstand foodprocessing conditions such as acids, drying, preservatives, and disinfectants, when compared to other Salmonella serotypes. Human infections of DT 104 have been associated with eating contaminated meat products. Controlling multi-drug resistant Salmonella would require avoidance of unnecessary antibiotic usage by the poultry industry.

Competitive exclusion (CE)

A promising approach to reduce Salmonella in live birds is CE. This approach, the “Nurmi Concept,” was first reported by Nurmi and Rantala (1973). Pivnick and Nurmi (1982) summarized the CE concept as follows: (i) newly hatched chicks may be colonized by a single cell of Salmonella; (ii) older birds are more resistant to Salmonella colonization because of a mature, complex gut microflora; and (iii) introduction of pathogen-free intestinal/cecal contents or scrapings from a healthy, adult bird into a day-old chick speeds up maturation of gut microflora. This mature microflora increases the resistance of most chicks to Salmonella 
colonization. Studies have conclusively shown that CE is an effective approach to Salmonella control (Snoeyenbos et al., 1978; Pivnick et al., 1981; Bailey, 1988; 1993). Competitive exclusion cultures may exclude Salmonella by (1) competing for attachment sites and nutrients in the intestine; (2) excreting metabolic products such as bacteriocins, volatile fatty acids, lactic acid, and hydrogen sulfide that are toxic to Salmonella; and/or (3) creating an intestinal environment conducive to the growth of obligate anaerobes. The exact mechanism(s) of action remains unknown.

Two types of CE cultures, undefined (bacterial composition unknown) and defined (known bacterial composition) are used (Stavric and D'Aoust, 1993; Mead, 1998). Studies have been carried out during the past decade to determine the laboratory and field efficacy of undefined and defined CE cultures. Undefined CE cultures offered protection to chicks when challenged with a standard dose of Salmonella under laboratory conditions (Stavric and D’Aoust, 1993; Nisbet et al., 1996; Palmu and Camelin, 1997; Corrier et al., 1998; Fukata et al., 1999; Hume et al., 1998). However, field study results have been variable. Protective capacity of undefined cultures is influenced by source of microflora, culture conditions, methods of administration, presence of feed additives, in-laboratory or natural environmental Salmonella challenge, and hygienic practices on the farm (Bailey, 1987; Savage, 1987). Formulation of undefined cultures has been difficult due to insufficient knowledge of microbial ecology, isolation/detection techniques, underlying protective mechanisms, and host (bird)-microbe and microbe-microbe interactions in the GI tract. Defined cultures are less effective than undefined cultures under laboratory conditions and afford little protection against Salmonella colonization (Stavric, 1987; Corrier et al., 1993; Stavric and D’Aoust, 1993). Potency of defined cultures decreases with storage and manipulation of isolates. Commercial CE preparations such as 
Aviguard, Avi-Free, Broilact, CF3, Preempt, and Mucosal CE are currently available (Smith, 1997; Nisbet et al., 1998). Yeast (Saccharomyces boulardii) has also been used to reduce Salmonella associated with broiler chickens (Line et al., 1997). Competitive exclusion treatment should be complemented by biosecurity measures, vaccination programs, HACCP protocols, and stringent hygiene practices on the farm to protect poultry from natural Salmonella challenge.

\section{$\underline{\text { Vaccination }}$}

Prophylactic vaccination is another method of preventing vertical transmission of Salmonella. Bacterins and live attenuated cultures have been used as vaccines in the prevention of avian salmonellosis (Nagaraja and Back, 1998). Components, such as ribosomes, outer membrane proteins, and polysaccharide-protein conjugates extracted from Salmonella have also been investigated as potential vaccines (Nagaraja et al., 1982; 1984; 1985; 1988). An experimental vaccine prepared from an acetone-killed, S. enteritidis oil emulsion reduced incidence and level of intestinal colonization by S. enteritidis in poultry feces at 1 week when post-challenge with $10^{8} \mathrm{CFU}$ (Gast et al., 1993). A vaccine prepared from killed S. typhimurium, expressing high amounts of type 1 fimbriae, has been effective in lowering Salmonella colonization in the cecal junction, liver and spleen. Killed vaccines do not induce sufficient protection to eliminate non-specific Salmonella serotypes colonizing chickens. Vaccines prepared from live but attenuated Salmonella strains (gallinarum, typhimurium, choleraesuis, and enteritidis) have produced variable protection depending on delivery route and ability of the attenuated strain to survive the host (Pritchard et al., 1978; Barrow et al., 1987; 1998; Barrow, 1990; Barrow et al., 1990a; 1990b; 1998; Hassan and Curtis, 1994). 


\section{Control of Salmonella During Processing}

Processes in a poultry slaughter facility may cause a serious threat if not controlled on a regular basis.

\section{$\underline{\text { Sources of contamination }}$}

Although the frequency of Salmonella-positive birds entering a processing plant is generally low (National Advisory Committee on Microbiological Criteria in Foods, 1997), there are several opportunities for carcass cross-contamination during slaughter and subsequent processing (Bryan et al., 1968; Morris et al., 1969; May, 1974; Lillard, 1990). Rate of Salmonella contamination, either from processing plants or retail markets, varies from 5 to $100 \%$ on broiler carcasses (Todd, 1980; Humphrey et al., 1988; Lammerding et al., 1988; Carraminana et al., 1997; National Advisory Committee on Microbiological Criteria in Foods, 1997). Possible sources of Salmonella contamination during poultry processing are summarized in Table 2 (Russell, 1998). Reviews on microbial contamination associated with individual processing steps have been reported (Bryan and Doyle, 1995; National Advisory Committee on Microbiological Criteria in Foods, 1997; Russell, 1998).

$\underline{\text { Intervention strategies in the processing plant }}$

Although broiler slaughter operations do not include thermal processes that ensure elimination of Salmonella, a number of processing steps can be controlled to minimize and reduce microbiological hazards. Implementation of HACCP protocols in the slaughter facility and several chemical and physical treatments of broiler carcasses reduce/eliminate Salmonella associated with fresh poultry.

The goals of HACCP for poultry slaughter operations are to prevent, eliminate, or reduce the incidence and level of pathogenic microorganisms such as Salmonella and Campylobacter 
and to control bacterial recontamination and/or outgrowth (National Advisory Committee on Microbiological Criteria in Foods, 1997). In general, HACCP can be defined as a systematic, scientific approach used in food production to ensure food safety (National Advisory Committee on Microbiological Criteria in Foods, 1998). It involves seven principles: (1) to assess hazards and risks associated with the process. A food safety hazard includes any biological, chemical or physical agent that is reasonably likely to cause illness or injury in the absence of its control; (2) to determine critical control points $(\mathrm{CCP})$ for identified hazards. A CCP is any step in the process at which control can be applied in order to prevent/eliminate a food safety hazard or to reduce it to an acceptable level; (3) to establish critical limits at each CCP to control the hazards. Critical limits are based on process parameters such as temperature, time, $\mathrm{pH}$, water activity, salt concentration, and sensory information; (4) to establish reliable procedures to monitor CCP's. Monitoring frequencies must be sufficient to ensure optimal control of CCP's; (5) to establish corrective actions when there is a deviation identified during monitoring a CCP. Actions must eliminate the hazard and ensure safe disposition of the product; (6) to establish record keeping and documentation procedures. The HACCP plan, CCP documentations, and modifications made in HACCP or CCP plans should be included in the file; and (7) to establish verification procedures confirming that the HACCP system is working correctly.

Regulatory agencies have poultry processing companies switch from organoleptic to science-based inspection. This inspection includes microbiological testing and mandatory reporting of any incidence of pathogen recovery, and identification of actual sources of contamination and cross-contamination, and visual examination of carcasses for fecal contamination. Federal regulations mandate all poultry processing plants to implement an inhouse HACCP protocol. To verify that HACCP systems are effective, the Food Safety and 
Inspection Service (FSIS) has set performance standards for Salmonella that slaughter plants producing ground meat and poultry have to meet. According to the "Mega-Reg" policy implemented by the federal agencies, meat slaughtering facilities in the U.S. are required to meet performance standards for Salmonella in order to verify the effectiveness of their HACCP plans (Anon, 1996). This policy was mandated on January 27, 1997 for meat processing plants in the U.S. Sampling and testing for Salmonella is carried out on an unannounced basis by federal inspectors. Failure to meet performance standards (Table 3) requires a plant to take immediate action to meet the guidelines. If the company fails consistently, the FSIS suspends inspection services.

In the slaughter facility, CCP's fall into two categories (Fig. 2): (1) preventive measures to avoid colonization of carcasses with Salmonella. These measures include adequate live-bird surveillance on the farm, surveillance of personnel handling the birds, pest control, equipment sanitation, safe water supply, and good manufacturing practices in the processing units (McCapes et al., 1991); and (2) risk minimization measures to limit spread of Salmonella from contaminated carcasses. These measures include chlorination of carcass rinse water, refrigeration, equipment cleaning and disinfection procedures, and personnel sanitation.

Several intervention strategies have been attempted to rid raw poultry carcasses of Salmonella and other poultry pathogens. Presently, commercial processing plants in the U.S. use 20-50 ppm chlorine disinfectant (3-5 ppm residual chlorine) in immersion chillers (Thomson et al., 1979; Tamblyn et al., 1997). Chlorine has been widely used because it is safe (GRAS status), readily available, and inexpensive (Tsai et al., 1991). Chlorine (20 ppm) has also been used by slaughter facilities to disinfect equipment surfaces, carcass rinse cabinets, and the insideoutside bird washer prior to the chiller. However, chlorinated immersion and spray methods of 
carcasses have been relatively ineffective against Salmonella due to the large amounts of organic matter (blood and feces) (Hargis et al., 1998).

Another factor that affects bactericidal properties of chlorine is $\mathrm{pH}$. In water, chlorine dissociates into hypochlorous acid (powerful disinfectant) and hypochlorite ion (weak disinfectant). Poultry chill water has a $\mathrm{pH}$ of 7.6 to 8.0 . At this $\mathrm{pH}$, less than $60 \%$ of the chlorine is available in the form of hypochlorous acid (Waldroup, 1998). However, if chill water $\mathrm{pH}$ is maintained between $6.0-6.5$, about $95-98 \%$ of the chlorine would be available as hypochlorous acid. Hence, chill water tanks are injected with $\mathrm{CO}_{2}$ that forms carbonic acid thereby reducing $\mathrm{pH}$ of the chill water.

Alternative decontamination methods have been investigated as potential replacements for chlorine as the standard disinfectant. Chlorine dioxide (1.5 to $3.0 \mathrm{ppm}$ residual chlorine) has been permitted in U.S. poultry processing plants (Lillard, 1979; 1980; Waldroup, 1998). However, high cost and skin discoloration of raw carcasses have limited its use. Trisodium phosphate ( 8 to $12 \%$ ) has also been approved for use in processing units to reduce Salmonella and other foodborne pathogens (Giese, 1993; Tamblyn et al., 1997).

Several physical and chemical approaches such as air scrubbing (Dickson and Cox, 1992), heat (Davidson et al., 1985; Morrison and Fleet, 1985), irradiation (Mulder et al., 1977; Hanis et al., 1989; Thayer et al., 1991; Thayer, 1995; Abu-Tarboush et al., 1997), ozone (Yang and Chen, 1979; Sheldon and Brown, 1986; Waldroup, 1998), and several organic acids and chemicals have been used to reduce/eliminate Salmonella on carcasses and to minimize crosscontamination (Conner and Bilgili, 1994; Hwang and Beuchat, 1995; Tamblyn and Conner, 1997; Tamblyn et al., 1997; Xiong et al., 1998; Yang et al., 1998). The Food and Drug Administration (FDA) has approved irradiation of refrigerated or frozen uncooked meat, meat by 
products, and certain meat products to control foodborne pathogens and extend product shelf life (FDA, 1997). Organic acids such as lactic, acetic, citric, malic, propionic, and tartaric acid reduce Salmonella levels on poultry carcasses (Snijders et al., 1985; van der Marel et al., 1988; Hwang and Beuchat, 1995; Kolsarchi and Candogan, 1995; Tamblyn and Conner, 1997). Among several chemical treatments, phosphates (Kim and Slavik, 1994; Lillard, 1994; Hwang and Beuchat, 1995; Salvat et al., 1997; Wang et al., 1997; Coppen et al., 1998), hydrogen peroxide (Lillard and Thomson, 1983), quaternary ammonium salts (Breen et al., 1995; Wang et al., 1997), glutaraldehyde (Thomson et al., 1977), sorbates (Robach and Sofos, 1982; Kolsarchi and Candogen, 1995), Tween 80 (Hwang and Beuchat, 1995), and a combination of lysozyme and EDTA (Samuelson et al., 1985) have been found to be effective in reducing Salmonella contamination on poultry carcasses.

Although these approaches reduce Salmonella on fresh poultry, they could adversely affect taste, color, flavor, texture, and/or appearance of the product (Breen et al., 1995; Hargis et al., 1998). Existing technologies reduce, but rarely eliminate, Salmonella on carcasses during processing because they are ineffective against bacterial cells that are attached to skin.

\section{Salmonella attachment to poultry skin/carcasses}

Salmonella incidence on broiler carcasses increases with successive stages of processing, possibly due to the ability of the pathogen to firmly attach to poultry tissue or skin (Lillard, 1986a; b; 1989a; b). According to Lillard (1989b), "attached" bacteria can be defined as bacteria that remain on the skin after exposure to a bacterial cell suspension for a predetermined time and following rinsing for one min under running water at 50 psi. Lillard (1989a) demonstrated that Salmonella are firmly attached to poultry skin before broilers arrive at the slaughter facility, and high levels are recovered after 40 consecutive whole carcass rinses of a single carcass. 
Salmonellae were not always recovered in the first whole carcass rinse and this sampling method could result in false negative reports. Attachment of Salmonella to poultry skin or the avian intestinal tract is complex and the mechanism(s) of action are not well understood.

The mechanism of bacterial attachment involves two steps (Kim and Doores, 1993). The first step involves retention of bacteria in a liquid film on the surface of skin and meat after immersing the sample in the bacterial suspension (Thomas and McMeekin, 1981; Lillard, 1986a; 1986b; Thomas et al., 1987). Thomas and McMeekin (1984) demonstrated that, in the first $15 \mathrm{~s}$ of immersion, over $90 \%$ of S. typhimurium cells were in the water film and less than $10 \%$ were recovered from the skin samples. However, after 30 to 60 min of immersion, 40 and $60 \%$ of cells were recovered from the skin, respectively, and fewer were found in the water film. These results indicate that there is a transfer of cells from the water film to the skin as immersion time increases. Contamination of carcasses by Salmonella during immersion processes can be reduced by preventing formation of the surface film, and by altering the surface tension. Scanning electron micrographs have shown that Salmonella appears to be entrapped in deep crevices or ridges that become more prominent after immersing poultry skin and muscle in water (Lillard, 1988). Salmonella cells lodged in these crevices or ridges of the skin are protected and not easily accessible. Certain chemical treatments used in chill water are effective in reducing salmonellae to nondetectable levels, but did not completely eliminate them from the carcasses (Lillard, 1979; 1980; Lillard and Thomson, 1983; Lillard et al., 1987).

Firstenberg-Eden (1981) reported that bacteria are closely associated with each other and entrapped in certain inaccessible sites by physical forces. Attachment at this stage is reversible and balanced between attractive van der Waals and repulsive electrostatic forces (Gristina, 1987). Adhesion depends on characteristics of the bacterium, the surrounding medium, and the 
substrate surface to be colonized. Bacteria approach the binding site with flagella in motile organisms or through fluid flow or external propulsion in motile and non-motile organisms (Benedict, 1988). Although both surfaces (bacterial and meat tissue) possess a net negative surface charge favoring repulsion, variations in isoelectric points, through localized changes in the microenvironmental $\mathrm{pH}$, may allow the two surfaces to approach within the minimum van der Waals forces, favoring attraction (Benedict, 1988).

The second step of attachment is characterized by a time-dependent, irreversible exopolymer formation. At this stage, bacteria multiply and form a microcolony, which can lead to the formation of a biofilm. Formation of these extracellular polysaccharides (glycocalyx) or attachment fibrils has been involved in the attachment process (Costerton et al., 1978; Butler et al., 1979; 1980; Schwach and Zottola, 1982).

The strongest form of Salmonella attachment involves high-affinity chemical attachment to specific receptor sites. Little is known about the mechanisms involved in the chemical attachment of Salmonella to avian intestinal tract or skin surfaces. Duguid and coworkers (1966) found that $S$. typhimurium exhibited adhesive properties due to type 1 pili. Adhesive properties of type 1 pili were inhibited by D-mannose. On the other hand, Jones and workers (1980) found that type 1 pili were not involved in the attachment of $S$. typhimurium to HeLa cells. Cell adhesin, released during homogenization of S. typhimurium cells, inhibited attachment of the organisms to the HeLa cell receptor. Authors confirmed the presence of a cell-bound, Dmannose resistant hemagglutinin that was responsible for attachment of $S$. typhimurium to HeLa cells. Inhibition of in vitro attachment of Salmonella to inverted ceca (McHan et al., 1989) and intestinal segments (Oyofo et al., 1989a) by D-mannose and inhibition of colonization in broilers by D-mannose (Oyofo et al., 1989b) indicated that mannose-sensitive adhesion (associated with 
type 1 fimbriae) plays a major role in the colonization of the avian intestinal tract by salmonellae (Craven and Williams, 1998). Lillard (1986b) also found that mannose-sensitive type 1 fimbriae, isolated from S. typhimurium, were responsible for attachment of the organism to chicken skin.

Attachment of microorganisms depends on the presence of flagella and their activity (Notermans and Kampelmacher, 1974; Butler et al., 1979; Farber and Idziak, 1984). Flagellated bacteria readily attach and nonflagellated bacteria rarely attach to poultry skin. Bouttier et al. (1997) observed a 90\% reduction in S. choleraesuis attachment to beef muscle tissues after mechanically removing the flagella or treating the bacteria with specific antiflagella serum. Authors attributed this reduction to a loss of bacterial mobility leading to a reduction in the number of bacterial cells reaching the tissue during the period of contact. Salmonella attachment has also been associated with connective tissue, particularly collagen (Thomas and McMeekin, 1981; Benedict et al., 1991; Kim and Doores, 1993; Walls et al., 1993). Adhesion to hyaluronan has been identified as the likely explanation (Sanderson et al., 1991). Benedict (1988) demonstrated that $S$. typhimurium attached to fresh meat surfaces by selectively binding to collagen fibers, particularly the reticulin type. Lipopolysaccharides and hydrophobic bonding have contributed to in vitro attachment of S. typhimurium and $S$. california cells to chicken cecal mucus and enterocytes (Craven et al., 1992; Craven, 1994). The phenomenon of Salmonella attachment to poultry skin/tissue or the intestinal tract involves more than one mechanism. Water uptake and type of fimbriae, flagella, and cell wall components may, alone or in combination, influence Salmonella attachment to poultry skin.

Reduction of Salmonella will depend on the extent of fecal contamination within the production facility. Use of non-pathogenic E. coli, as an indictor of fecal contamination, merits 
consideration in monitoring fecal contamination and thus, controlling overall sanitation on poultry farms.

\section{Significance of Generic Escherichia coli as an Indicator Organism}

Fecal coliforms are generally found in the gastrointestinal tract of humans and warmblooded animals. They include members of at least three genera: Escherichia, Klebsiella, and Enterobacter.

According to FSIS, generic (non-pathogenic) E. coli is an ideal indicator of good manufacturing practices within processing units (USDA-FSIS, 1996). This organism has also been chosen as a measure of assessing control in poultry slaughtering facilities (USDA, 1996). The new FSIS Pathogen Reduction/Hazard Analysis and Critical Control Point (HACCP) regulation, also referred to as "Mega-Reg" policy, codifies the principles of pathogen prevention and reduction. This policy, published in July 1996, provides food safety inspectors with systematic science-based tools to carry out inspections of raw carcasses in all federally inspected meat and poultry slaughter and processing operations in the U.S. The FSIS estimated that total cost of implementation by meat and poultry industries will be between $\$ 305$ to $\$ 357$ million (Anon, 1996).

Sanitation standard operating procedures (SOP's), establishment and maintenance of HACCP plans, and microbiological testing of generic E. coli for process control are the focal points of this policy. Sanitation SOP's were required to develop, implement, maintain, and document ongoing sanitary measures in the plant by January 1997. All establishments were required to implement a $\mathrm{HACCP}$ protocol for each final product. Implementation was dependent on the plant size. The HACCP plan in large (>500 employees) and smaller (10 to 499 employees) plants was implemented by January 26, 1998 and January 25, 1999, respectively. 
Very small plants ( $<10$ employees or annual sales $<\$ 2.5$ million) have a HACCP plan in place since January 25, 2000 (Anon, 1996).

In accordance with the "Mega-Reg" policy, slaughter facilities have been testing generic E. coli since January 27, 1997. Federal regulations require plants to test for E. coli in order to verify that the slaughter process is removing or preventing fecal contamination on carcasses. $E$. coli was selected as the test organism because enumeration is useful to insure that processing parameters are in control, analysis is easy and inexpensive, and E. coli can be easily quantified when compared to pathogens such as Salmonella, Campylobacter, and Listeria (Russell, 1996). Smaller plants, annually producing less than 6,000 cattle, 20,000 pigs, 440,000 chickens, or 60,000 turkeys were required to collect one sample per week during June to August period for $E$. coli testing. Sampling criterion for larger plants is shown in Table 4 (Anon, 1996). A survey (1992 to 1998) conducted by FSIS found that $99.6 \%$ of broilers, $98.9 \%$ of turkey, $99.3 \%$ of ground chicken, and $84.4 \%$ of ground turkey were contaminated with generic E. coli, while $99.9 \%$ of broilers, $99.8 \%$ of turkey, $99.7 \%$ of ground chicken, and $95.5 \%$ of ground turkey were contaminated with fecal coliforms (McNamara and Levine, 1998). Establishments sampled in this program were responsible for slaughtering approximately $99.9 \%$ of all broiler and turkeys slaughtered in the U.S. and for producing $100 \%$ of the ground chicken and turkey under federal inspection.

Generic E.coli has been reported as the best indicator of fecal contamination on poultry carcasses (USDA-FSIS, 1996). Fecal contamination is the primary route by which enteric bacteria such as Salmonella, Campylobacter, and E. coli O157:H7 gain access to meat and poultry. Escherichia coli can be considered as an "index" organism because its presence could be used to indicate the presence of other pathogenic organisms. However, generic E. coli and fecal 
coliforms do not have a reliable and defined relationship with poultry pathogens because of differences in physiology, growth requirements, and growth characteristics (Solberg et al., 1977).

While E. coli levels may be affected by processing parameters, environmental conditions to which birds are exposed before entering the slaughter facility may also have an impact on the contamination level. Fecal matter present on the outside of birds as they enter the plant may influence $E$. coli levels on the carcasses, regardless of efforts to reduce contamination during processing. Feed withdrawal before transportation could influence the level of $E$. coli contamination. Feed is normally withheld for 6-7 hours before being shipped to the slaughter plants. If they are not withheld from feed for a sufficient period, these birds will have their intestines full of ingesta that are likely to rupture during evisceration and eventually leak onto the carcasses. If feed withdrawal is too long $(>12 \mathrm{~h})$, the intestines begin to slough their mucosal lining, which weakens the intestine and makes it more susceptible to tearing during evisceration (Russell, 1996). Although such factors are not plant related, under current guidelines, the processor maybe ultimately responsible for $E$. coli incidences.

\section{Consumer Food Safety}

Nearly $85 \%$ of outbreaks associated with foodborne diseases occurs as a result of food mishandling in food service establishments and homes (Hall, 1997). Food safety measures implemented by the industry and federal agencies to govern pre- and post-harvest control of foodborne outbreaks/illnesses will be of no avail if the consumer mishandles/abuses raw or processed foods. Therefore, it is important to heighten consumer awareness and encourage food safety training and education among consumers and personnel associated with food service establishments. Knabel (1985) reported the top eleven factors contributing to outbreaks associated with foodborne diseases caused by mishandling of household foods in the U.S. They 
were ranked as follows: (1) contaminated raw food/ingredients; (2) inadequate heat processing;

(3) procuring food from unsafe source; (4) improper cooling; (5) lapse of $\geq 12 \mathrm{~h}$ between preparing and eating; (6) infected person handling the food; (7) improper fermentations; (8) inadequate reheating; (9) toxic containers; (10) improper hot holding; and (11) cross contamination.

General guidelines for handling poultry meat in retail food stores and food service establishments (National Advisory Committee on Microbiological Criteria for Foods, 1997)

The following precautionary measures should be taken to avoid the risk of foodborne diseases in restaurants and retail food establishments: Fresh raw broilers should be received in good condition at $\leq 41^{\circ} \mathrm{F}$ and visually inspected, and temperatures should be checked for product abuse. Products must be stored below $40^{\circ} \mathrm{F}$ to minimize growth of foodborne pathogens and they must be rotated on the first-in, first-out basis. All raw materials should be covered, properly dated, and labeled. Raw products must be separated from cooked products to avoid cross contamination. Coolers should be checked regularly for temperature fluctuations. Food service workers must be educated about risks associated with mishandling raw poultry during food preparation and distribution. Fresh products must be separated from processed products during food preparation. Equipment and utensils such as knives, cutting boards and pans used in preparing raw chicken must not be allowed to come in contact with processed foods. Contaminated equipment and utensils should be properly cleaned and sanitized after use. Chicken and turkey (whole and parts) products must be cooked to a minimum internal temperature of $180^{\circ} \mathrm{F}$, as measured in the thickest part of the breast muscle. Ground/restructured poultry products must be cooked to a minimum internal temperature of $165^{\circ} \mathrm{F}$ for $15 \mathrm{~s}$. Products such as rotisserie that are cooked and held for hot display should be kept at a minimum 
temperature of $140^{\circ} \mathrm{F}$. Leftover processed poultry products should be immediately refrigerated to prevent microbial growth. Leftovers and other precooked broiler parts should be reheated to an internal temperature of $165^{\circ} \mathrm{C}$ within two hours.

General guidelines for handling poultry meat by consumers (National Advisory Committee on Microbiological Criteria for Foods, 1997)

Consumers should take the following precautions in their kitchens to reduce the risk of foodborne illnesses: Perishable poultry products should be purchased after other grocery items have been selected. Raw products should be bagged separately to avoid contamination of other food products. Raw meat or poultry product should never be allowed to come in contact with a food package that will not be cooked before consumption. Raw poultry products must be immediately refrigerated $\left(<40^{\circ} \mathrm{F}\right)$ or frozen $\left(<0^{\circ} \mathrm{F}\right)$. The refrigerator and freezer should be cleaned and sanitized periodically. Raw products should be kept separately from cooked products. Kitchen countertops, sinks, and cutting surfaces should be cleaned and sanitized after they come in contact with any raw poultry product. Surfaces should be cleaned with soapy water, rinsed thoroughly, and sanitized with chlorine solution (one cap of bleach/gallon of cold water) or any available kitchen sanitizers. Cross-contamination can occur in the kitchen when utensils, plates, and hands are not thoroughly washed and sanitized before handling or preparing cooked foods or foods that will not be further processed (e.g. salads). Never use the same cutting board or plates for raw and cooked poultry products unless they have been washed and sanitized between uses. Frozen products should be thawed overnight in the refrigerator. Guidelines for cooking, refrigerating, and reheating (leftovers) whole and minced poultry products have been mentioned in the previous discussion. 
Although the above guidelines are directed toward reducing contamination of pathogens in poultry products, they could be applied to any meat product. Minimum cooking temperatures will vary with the type of meat product. In general, consumers, food safety establishments, and retail outlets should remember four key terms to fight foodborne diseases: (1) Clean: wash hands and surfaces often; (2) Separate: do not cross-contaminate; (3) Cook: cook to proper temperatures; and (4) Chill: refrigerate promptly.

\section{Concluding Remarks}

Microorganisms are naturally present in the environment and are found on most raw agricultural products. There are several means by which microbes, particularly foodborne pathogens such as Salmonella, Campylobacter, E. coli O157:H7, and Listeria, can enter a food system. Factors such as temperature, stress, and unsanitary conditions in the facility may contribute to pre- and post-harvest contamination. Pathogens can survive minimal preservation treatment(s) and can continue to multiply if food products are abused. Humans may introduce pathogens into food products during production, processing, distribution, storage, and preparation, prior to consumption. Depending on individual susceptibility (old age, infants, or immunocompromised), foodborne pathogens can inflict mild to life-threatening diseases. The public health system in the U.S. needs to develop a more efficient early-warning network than the currently existing Foodborne Disease Active Surveillance Network (FoodNet) and pathogen DNA fingerprinting (PulseNet), to detect, control and/or prevent foodborne outbreaks. Food safety research should involve more sensitive, rapid, and automated methods to accurately detect and characterize pathogens in food products.

Food companies should strictly adhere to the food safety regulations and guidelines implemented by the federal agencies. Food safety educational training programs should be made 
mandatory for personnel working in the food companies. Food safety workshops can be held through extension services at the universities to educate the public. More federal dollars must be invested in educating school students and consumers through regular food-safety related programs on television, radio, and the Internet. Controlling the incidence of foodborne pathogens in food products from "The Farm to the Table" must be a concerted effort on the part of all people involved in each segment of the food system - producers, integrators, shippers, retailers, processing companies, retailers, food service establishments, and consumers. 


\section{REFERENCES}

Abu-Tarboush, H., Al-Kahtani, H., Atai, M., Abou-Arab, A. Bajaber, A. and El-Mojaddidi, M. 1997. Sensory and microbial quality of chicken as affected by irradiation and postirradiation storage at $4.0^{\circ} \mathrm{C}$. J. Food Prot. 60:761-770.

Al-Chalaby, Z.A.M., Hinton, M.H. and Linton, A.H. 1985. Failure of drinking water sanitisation to reduce the incidence of natural Salmonella in broiler chickens. Vet. Rec. 116:364-365.

Amick-Morris, J. 1998. Insects' contribution to Salmonella transmission in turkey flocks. M.S. Thesis. West Virginia University, Morgantown.

Anonymous. 1996. News and Notes. Food Quality 3:7-10.

Anonymous. 1997. Multidrug-resistant Salmonella serotype typhimurium - United States. Morbidity \& Mortality Weekly Report 46:308-310.

Baggessen, D.C., Olsen, J.E. and Bisgaard, M. 1992. Plasmid profiles and phage types of Salmonella typhimurium isolated from successive flocks of chickens on three parent farms. Avian Pathol. 21:569-579.

Bailey, J.S. 1987. Factors affecting microbial competitive exclusion in poultry. Food Technol. 41:88-92.

Bailey, J.S. 1988. Integrated colonization control of Salmonella in poultry. Poultry Sci. 67:928-932.

Bailey, J.S. 1993. Control of Salmonella and Campylobacter in poultry production: A summary of work at Russell Research Center. Poultry Sci. 72:1169-1173.

Bailey, J.S., Cox, N.A., Blankenship, L.C. and Stern, N.J. 1992. Hatchery contamination reduces effectiveness of competitive exclusion treatments to control salmonellae colonization of broiler chicks. Poultry Sci. (Abstract) 71 (Suppl. 1):6.

Barnes, E.M., Mead, G.C., Barnum, D.A. and Harry, E.G. 1972. The intestinal flora of the chicken in the period 2 to 6 weeks of age with particular reference to the anaerobic bacteria. $\mathrm{Br}$. Poultry Sci. 13:311-326.

Barnes, E.M., Impey, C.S. and Cooper, D.M. 1980. Manipulation of the crop and intestinal flora of the newly hatched chick. Am. J. Clin. Nutr. 33:2426-2433.

Barrow, P.A. 1990. Immunity to experimental fowl typhoid in chickens induced by a virulence plasmid-cured derivative of Salmonella gallinarum. Infect. Immun. 58:2283-2288. 
Barrow, P.A., Hassan, J.O. and Berchieri, A. 1990a. Reduction in faecal excretion of Salmonella typhimurium strain F98 in chickens vaccinated with live and killed S. typhimurium organisms. Epidemiol. Infect. 104:413-426.

Barrow, P.A., Huggins, M.B., Lovell, M.A. and Simpson, J.M. 1987. Observations on the pathogenesis of experimental Salmonella typhimurium infection in chickens. Res. Vet. Sci. 42:194-199.

Barrow, P.A., Lovell, M.A. and Berchieri, A. 1990b. Immunisation of laying hens against Salmonella enteritidis phage type 4 with live, attenuated vaccines. Vet. Rec. 126:241-242.

Barrow, P.A., Zhang-Barber, L. and Turner, A.K. 1998. Live vaccines for control of Salmonella in poultry. Proc. Intl. Symp. on Food-borne Salmonella in Poultry. pp. 201-211. Baltimore, Maryland.

Baskerville, A., Humphrey, T.J., Fitzgeorge, R.B., Cook, R.W., Chart, H., Rowe, B. and Whitehead, A. 1992. Airborne infection of laying hens with Salmonella enteritidis phage type 4. Vet. Rec. 130:395-398.

Benedict, R.C. 1988. Microbial attachment to meat surfaces. Reci. Meat Conf. Proc. 41:1-6.

Benedict, R.C., Schultz, F.J. and Jones, S.B. 1991. Attachment and removal of Salmonella spp. on meat and poultry tissues. J. Food Safety 11:135-148.

Bennett, G. 1993. Cockroaches as carriers of bacteria. Lancet. 341:732-735.

Benson, C.E. and Munro, D.S. 1997. Salmonella typhimurium DT104 in the northeast USA. Vet. Rec. 8:503-504.

Bhatia, T.R.S. and McNabb, G.D. 1980. Dissemination of Salmonella in broiler-chicken operations. Avian Dis. 24:616-624.

Bhatia, T.R.S., McRobb, G.D., Wyman, H. and Rayer, G.P.S. 1979. Salmonella isolation from litter as an indicator of flock infection and carcass contamination. Avian Dis. 23:838-847.

Blankenship, L.C., Bailey, J.S., Cox, N.A., Stern, N.J., Brewer, R. and Williams, O. 1993. Two step mucosal competitive exclusion flora treatment to diminish salmonellae in commercial broiler chickens. Poultry Sci. 72:1667-1672.

Botts, C.W., Ferguson, L.C., Birkeland, J.M. and Winter, A.R. 1952. The influence of litter in the control of Salmonella infections in chicks. Am. J. Vet. Res. 13:562-566.

Bouttier, S., Linxe, C., Ntsama, C., Morgant, G., Bellon-Fontaine, M.N., and Fourniat, J. 1997. Attachment of Salmonella choleraesuis to beef muscle and adipose tissues. J. Food Prot. 60:1622. 
Breen, P.J., Compadre, C.M., Kim Fifer, E., Salari, H., Serbus, D.C. and Lattin, D.L. 1995. Quaternary ammonium salts inhibit and reduce the attachment of viable Salmonella typhimurium to poultry tissues. J. Food Sci. 60:1191-1196.

Bryan, F.L., Ayres, J.C. and Kraft, A.A. 1968. Contributory sources of salmonellae on turkey products. Am. J. Epidemiol. 87:578-591.

Bryan, F.L. and Doyle, M.P. 1995. Health risks and consequences of Salmonella and Campylobacter jejuni in raw poultry. J. Food Prot. 58:326-344.

Butler, J.L., Stewart, J.C., Vanderzant, C., Carpenter, Z.L. and Smith, G.C. 1979. Attachment of microorganisms to pork skin and surfaces of beef and lamb carcasses. J. Food Prot. 42:401406.

Butler, J.L., Vanderzant, C., Carpenter, Z.L., Smith, G.C., Lewis, R.E. and Dutson, T.R. 1980. Influence of certain processing steps on attachment of microorganisms to pork skin. J. Food Prot. 43:699-705.

Carraminana, J.J. Yanguela, J., Blanco, D., Rota, C., Agustin, A.I., Arino, A. and Herrera, A. 1997. Salmonella incidence and distribution of serotypes throughout processing in a Spanish poultry slaughterhouse. J. Food Prot. 60:1312-1317.

Cason, J.A., Cox, N.A. and Bailey, J.S. 1994. Transmission of Salmonella typhimurium during hatching of broiler chicks. Avian Dis. 38:583-588.

Clemmer, D.I., Hickey, J.L., Bridges, J.F., Schliessmann, D.J. and Shaffer, M.F. 1960. Bacteriological studies of experimental air-borne salmonellosis in chicks. J. Infect. Dis. 106:197-210.

Conner, D.E. and Bilgili, S.F. 1994. Skin attachment model for improved laboratory evaluation of potential carcass disinfectants for their efficacy against Salmonella attached to broiler skin. J. Food Prot. 57:684-688.

Corrier, D.E., Hargis, B.M., Hinton, A., Lindsey, D., Caldwell, D.J., Manning, J. and Deloach, 1991. Effect of cecal colonization resistance of layer chicks to invasive Salmonella enteritidis. Avian Dis. 35:337-343.

Corrier, D.E., Nisbet, D.J., Byrd II, J.A., Hargin, B.M., Keith, N.K., Peterson, M. and Deloach, J.R. 1998. Dosage titration of a characterized competitive exclusion culture to inhibit Salmonella colonization in broiler chickens during growout. J. Food Prot. 61:796-801.

Corrier, D.E., Nisbet, D.J., Hollister, A.G., Scanlan, C.M., Hargis, B.M. and Deloach, J.R. 1993. Development of defined cultures of indigenous cecal bacteria to control salmonellosis in broiler chicks. Poultry Sci. 72:1164-1168. 


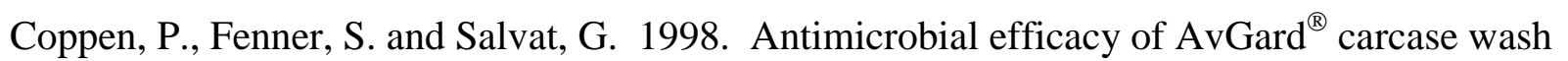
under industrial processing conditions. Br. Poultry Sci. 39:229-234.

Costerton, J.W., Geesey, G.G. and Cheng, K.-J. 1978. How bacteria stick. Sci. Am. 238:86-95.

Cox, N.A. 1998. Incidence and impact of salmonellae in broiler hatcheries. Proc. Intl. Symp. on Food-borne Salmonella in Poultry. pp. 88-92. Baltimore, MD.

Cox, N.A., Bailey, J.S., Mauldin, J.M., Blankenship, L.C. and Wilson, J.L. 1991. Extend of salmonellae contamination in the breeder hatcheries. Poultry Sci. 70:416-418.

Cox, N.A., Bailey, J.S., Thomson, J.E. and Juven, B.J. 1983. Salmonella and other Enterobacteriaceae found in commercial poultry feed. Poultry Sci. 62:2169-2175.

Cox, N.A., Bailey, J.S., Mauldin, J.M. and Blankenship, L.C. 1990. Presence and impact of salmonellae contamination in the commercial integrated broiler hatchery. Poultry Sci. 69:16061609.

Craven, S.E. 1994. Altered colonizing ability for the ceca of broiler chicks by lipopolysaccharide-deficient mutants of Salmonella typhimurium. Avian Dis. 38:401-408.

Craven, S.E., Cox, N.A., Bailey, J.S. and Blankenship, L.C. 1992. Binding of Salmonella strains to immobilized intestinal mucosal preparations from broiler chickens. Avian Dis. 36:296-303.

Craven, S.E. and Williams, D.D. 1998. In vitro attachment of Salmonella tyhimurium of chicken cecal mucus: Effect of cations and pretreatment with Lactobacillus spp. isolated from the intestinal tracts of chickens. J. Food Prot. 61:265-271.

D’Aoust, J.Y. 1991. Pathogenicity of foodborne Salmonella. Int. J. Food Microbiol. 12:17-20.

D’Aoust, J.Y. 1997. Salmonella species In. Food Microbiology: Fundamentals and Frontiers. Eds. M.P. Doyle, L.R. Beuchat and T.J. Montville. pp 129-158. ASM Press, Washington D.C.

D'Aoust, J.Y., Warburton, D.W. and Sewell, A.M. 1985. Salmonella typhimurium phage-type 10 from cheddar cheese implicated in a major Canadian foodborne outbreak. J. Food Prot. 48:1062-1066.

Davidson, C.M., D’Aoust, J.-Y. and Allwell, W. 1985. Steam decontamination of whole and cut-up raw chicken. Poultry Sci. 64:765-767.

Davies, R.H. and Wray, C. 1994. Salmonella in poultry units and associated enterprises. In. Pollution in Livestock Systems Ed. 1. Eds. A.P. Dewi, R.F.F. Axford, I. Marai and H. Umed. pp 137-166. CAB Oxford, England. 
Davies, R.H. and Wray, C. 1995. Contribution of the lesser mealworm beetle (Alphitobius diaperinus) to carriage of Salmonella enteritidis in poultry. Vet. Rec. 137:407-408.

Dickson, J.A. and Cox, N.A. 1992. The effect of air scrubbing on moisture pickup, aerobic plate counts, Enterobacteriaceae and the incidence of Salmonella on artificially inoculated broiler carcasses. Poutlry Sci. 71:560-564.

Dougherty, T.J. 1976. A study of Salmonella contamination in broiler flocks. Poultry Sci. 55:1811-1814.

Duguid, J.P., Anderson, E.S. and Campbell, I. 1966. Fimbriae and adhesive properties in salmonellae. J. Pathol. Bacteriol. 92:107-111.

Fanelli, M.J., Sadler, W.W. and Brownell, J.R. 1970. Preliminary studies on persistence of salmonellae in poultry litter. Avian Dis. 14:131-141.

Fanelli, M.J., Sadler, W.W., Franti, C.E. and Brownell, J.R. 1971. Location of salmonellae within the intestinal tract of chickens. Avian Dis. 15:366-395.

Farber, J.M. and Idziak, E.S. 1984. Attachment of psychrotrophic meat spoilage bacteria to muscle surfaces. J. Food Prot. 47:92-96.

Firstenberg-Eden, R. 1981. Attachment of bacteria to meat surfaces: A review. J. Food Prot. 44:602-607.

Food and Drug Administration. 1997. Irradiation in the reduction, processing, and handling of food. Federal Register 62:64107-64121.

Fukata, T., Sasai, K., Miyamoto, T. and Baba, E. 1999. Inhibitory effects of competitive exclusion and fructooligosaccharides, singly and in combination, on Salmonella colonization of chicks. J. Food Prot. 62:229-233.

Gast, R.K. and Stevens, J.F. 1988. Effects of kanamycin administration to poultry on the proliferation of drug-resistant Salmonella. Poultry Sci. 67:689-698.

Gast, R.K., Stone, H.D. and Holt, P.S. 1993. Evaluation of the efficacy of oil-emulsion bacterins for reducing fecal shedding of Salmonella enteritidis in laying hens. Avian Dis. 37:1085-1091.

Gauger, H.C. and Greaves, R.E. 1946. Isolations of Salmonella typhimurium from drinking water in a infected environment. Poultry Sci. 25:476-478.

Giese, J. 1993. Salmonella reduction process receives approval. Food Technol. 47-110-112.

Glisson, J.R. 1998. Use of antibiotics to control Salmonella in poultry. Proc. Intl. Symp. on Food-borne Salmonella in Poultry. pp. 173-175. Baltimore, MD.pp 173. 
Greenburg, B., Kowalski, J.A. and Klowden, M.J. 1970. Factors affecting the transmission of salmonellae by flies: Natural resistance to colonization and bacterial interference. Infect. Immun. 2:800-809.

Gordon, R.F. and Tucker, J.F. 1965. The epizootology of Salmonella menston infection of fowls and the effect of feeding poultry food artificially infected with Salmonella. Br. Poultry Sci. 6:251-264.

Gristina, A.G. 1987. Biomaterial-centered infection: Microbial adhesion versus tissue integration. Science 237:1588-1595.

Hacking, W.C., Mitchell, W.R. and Carlson, H.C. 1978. Sources of salmonellae in broiler chickens in Ontario. Can. J. Comp. Med. 42:392-399.

Hall, R.L. 1997. Foodborne Illness: Implications for the future. Emer. Infect. Dis. 3:555-559.

Hanis, T., Jelen, P., Klir, P., Mnukova, J., Perez, B. and Pesek, M. 1989. Poultry meat irradiation - effect of temperature on chemical changes and inactivation of microorganisms. J. Food Prot. 52:26-29.

Hargis, B.M., Caldwell, D.J., Brewer, R.L., Corrier, D.E. and DeLoach, J.R. 1995. Evaluation of the chicken crop as a source of Salmonella contamination for broiler carcasses. Poultry Sci. 74:1548-1552.

Hargis, B.M., Caldwell, D.J., Byrd, J.A., Corrier, D.E. and Stanker, L.H. 1998. Preharvest crop contamination and Salmonella recovery from broiler carcasses at processing. Proc. Intl. Symp. on Food-borne Salmonella in Poultry. pp. 220-231. Baltimore, MD.

Hassan, J.O. and Curtis, R. 1994. Development and evaluation of experimental vaccination program using a live-avirulent Salmonella typhimurium strain to protect immunized chickens against challenge with homologous and heterologous Salmonella serotypes. Infect. Immun. 62:5519-5527.

Henzler, D.J. and Opitz, H.M. 1992. The role of mice in the epizootiology of Salmonella enteritidis infection in chicken layer farms. Avian Dis. 36:625-631.

Higgins, R., Malo, R., Rene-Roberge, E. and Gauthier, R. 1982. Studies on the dissemination of Salmonella in nine broiler-chicken flocks. Avian Dis. 26:26-33.

Holder, G.T. 1998. Meat-type poltry industry initiatives to control Salmonella. Proc. Intl. Symp. on Food-borne Salmonella in Poultry. pp. 70-74. Baltimore, MD.

Holmberg, S.D., Osterholm, M.T., Senger, K.A. and Cohen, M.L. 1984. Drug-resistant Salmonella from animal fed antimicrobials. N. Eng. J. Med. 311:617-622. 
Hoover, N.J. 1996. Sources of Salmonella colonization in turkey production. M.S. Thesis. West Virginia University, Morgantown.

Hoover, N.J., Kenney, P.B., Amick, J.D. and Hypes, W.A. 1997. Preharvest sources of Salmonella colonization in turkey production. Poultry Sci. 76:1232-1238.

Hume, M.E., Corrier, D.E., Nisbet, D.J. and Deloach, J.R. 1998. Early Salmonella challenge time and reduction in chick cecal colonization following treatment with a characterized competitive exclusion culture. J. Food Prot. 61:673-676.

Humphrey, T.J., Mead, G.C. and Rowe, B. 1988. Poultry meat as a source of human salmonellosis in England and Wales. Epidem. Infect. 100:175-184.

Hwang, C-A. and Beuchat, L.R. 1995. Efficacy of selected chemicals for killing pathogenic and spoilage microorganisms on chicken skin. J. Food Prot. 58:19-23.

Jones, P.W. and Twigg, G.I. 1976. Salmonellosis in wild animals. J. Hyg. 77:51-54.

Jones, T.T., Axtell, R.C., Rives, D.V., Scheideler, S.E., Tarver, Jr. F.R., Walker, R.L. and Wineland, M.J. 1991. A survey of Salmonella contamination in modern broiler production. J. Food Prot. 54:502-507.

Jones, W. Morring, K., Olenchock, S.A., Williams, T. and Hickey, J. 1984. Environmental study of poultry confinement buildings. Am. Ind. Hyg. Assoc. J. 45:760.

Jones, G.W., Richardson, L.A. and Vanden Bosch, J.L. 1980. Phases in the interaction between bacteria and animal cells. In. Microbial Adhesion to Surfaces. pp 211. Ellis Harwood Ltd., Chichester, England.

Kapperud, G., Gustavsen, S., Hellesnes, I., Hansen, A.H., Lassen, J., Hirn, J., Kahkola, M., Montenegro, M.A. and Helmuth, R. 1990. Outbreak of Salmonella typhimurium infection traced to contaminate chocolate and caused by a strain lacking the 60-megadalton virulence plasmid. J. Clin. Microbiol. 28:2597-2601.

Kim, J-W. and Doores, S. 1993. Attachment of Salmonella typhimurium to skins of turkey that had been defeathered through three different systems: Scanning electron microscopic examination. J. Food Prot. 56:395-400.

Kim, J-W. and Slavik, M.F. 1994. Removal of Salmonella typhimurium attached to chicken skin by rinsing with trisodium phosphate solution: Scanning electron microscopic examination. J. Food Safety 14:77-84.

Keymer, I., Gibson, E.A. and Reynolds, D.J. 1991. Zoonoses and other findings in hedgehogs (Erinacaeus europaeus) - a survey of mortality and review of the literature. Vet. Rec. 128:245249. 
Knabel, S.J. 1985. Foodborne Illness: Role of home food handling practices. Food Technol. 49:119-131.

Kolsarchi, N. and Candogan, K. 1995. The effect of potassium sorbate and lactic acid on the shelf life of vaccum-packed chicken meats. Poultry Sci. 74:1884-1893.

Lahellec, C. and Colin, P. 1985. Relationship between serotypes of Salmonella from hatcheries and rearing farms and those from processed poultry carcasses. Br. Poultry Sci. 26:179-186.

Lammerding, A.M., Garcia, M.M., Mann, E.D., Robinson, Y., Dorward, W.J., Truscott, R.B. and Tittiger, F. 1988. Prevalence of Salmonella and thermophilic Campylobacter in fresh pork, beef, veal and poultry in Canada. J. Food Prot. 51:47-52.

Le Minor, L. 1981. The genus Salmonella. In. The Prokaryotes. Eds. M. P. Starr, H. Stolp, H.G. Truper, A. Balows and H.G. Schlegel. pp. 1148-1159. Springer-Verlag, New York.

Lillard, H.S. 1979. Levels of chlorine and chlorine dioxide of equivalent bactericidal effect in poultry processing water. J. Food Sci. 44:1594-1597.

Lillard, H.S. 1980. Effect on broiler carcasses and water of treating chiller water with chlorine or chlorine dioxide. Poultry Sci. 59:1761-1766.

Lillard, H.S. 1986a. Distribution of "attached" Salmonella typhimurium cells between poultry skin and a surface film following water immersion. J. Food Prot. 49:449-454.

Lillard, H.S. 1986b. Role of fimbriae and flagella in the attachment of Salmonella typhimurium to poultry skin. J. Food Sci. 51:54-56, 65.

Lillard, H.S. 1988. Effect of surfactant or changes in ionic strength on the attachment of Salmonella typhimurium to poultry skin and muscle. J. Food Sci. 53:727-730.

Lillard, H.S. 1989a. Factors affecting the persistence of Salmonella during the processing of poultry. J. Food Prot. 52:829-832.

Lillard, H.S. 1989b. Incidence and recovery of salmonellae and other bacteria from commercially processed poultry carcasses at selected pre- and post-evisceration steps. J. Food Prot. 52:88-91.

Lillard, H.S. 1990. The impact of commercial processing procedures on the bacterial contamination and cross-contamination of broiler carcasses. J. Food Prot. 53:202-204.

Lillard, H.S. 1994. Effect of trisodium phosphate on salmonellae attached to chicken skin. J. Food Prot. 57:465-469. 
Lillard, H.S., Blankenship, L.C., Dickens, J.A., Craven, S.E. and Shackelford, A.D. 1987. Effect of acetic acid on the microbiological quality of scalded picked and unpicked boiler carcasses. J. Food Prot. 50:112-114.

Lillard, H.S. and Thomson, J.E. 1983. Efficacy of hydrogen peroxide as a bactericide in poultry chiller water. J. Food Sci. 48:125-126.

Line, J.R., Bailey, J.S., Cox, N.A. and Stern, N.J. 1997. Yeast treatment to reduce Salmonella and Campylobacter populations associated with broiler chickens subjected to transport stress. Poultry Sci. 76:1227-1231.

May, K.N. 1974. Changes in microbial numbers during final washing and chilling of commercially slaughtered broilers. Poultry Sci. 53:1282-1285.

Mayes, F.J. and Takeballi, M.A. 1983. Microbial contamination of the hen's egg: A review. J. Food Prot. 46:1092-1098.

McCapes, R.H., Osburn, B.I. and Reimann, H. 1991. Safety of foods of animal origin: Model for elimination of Salmonella contamination of turkey meat. J. Am. Vet. Med. Assoc. 199:875880 .

McCapes, R.H. and Riemann, H.P. 1998. Obstacles to control of Salmonella in foods of avian origin. Proc. Intl. Symp. on Food-borne Salmonella in Poultry. pp. 23-42. Baltimore, MD.

McHan, F., Cox, N.A., Blankenship, L.C. and Bailey, J.S. 1989. In vitro attachment of Salmonella typhimurium to chick ceca exposed to selected carbohydrates. Avian Dis. 33:340344.

McIlroy, S.G. 1998. Control of Salmonella contamination of poultry feeds. Proc. Intl. Symp. on Food-borne Salmonella in Poultry. pp. 88-92. Baltimore, MD.

McMeekin, T.A., Thomas, C.J. and Pennington, P.I. 1984. Contamination and decontamination of poultry carcass neck tissue. J. Food Safety. 6:79-88.

McNamara, A.M. and Levine, P. 1998. Contamination of raw foods of avian origin. Proc. Intl. Symp. on Food-borne Salmonella in Poultry. pp. 56-69. Baltimore, MD.

Mead, G.C. 1998. Prospects for "competitive exclusion" treatment in controlling Salmonella and other pathogens in poultry. Proc. Intl. Symp. on Food-borne Salmonella in Poultry. pp. 176193. Baltimore, Maryland.

Milner, K.C. and Shaffer, M.F. 1952. Bacteriologic studies of experimental Salmonella infections in chicks. J. Inf. Dis. 90:81-86.

Morgan-Jones, S.C. 1980. The occurrence of Salmonella during the rearing of broiler birds. Br. Poultry Sci. 21:463-470. 
Morris, G.K., McMurray, B.L., Galton, M.M. and Wells, J.G. 1969. A study of the dissemination of salmonellosis in a commercial boiler chicken operation. Am. J. Vet. Res. 30:1413-1421.

Morrison, G.J. and Fleet, G.H. 1985. Reduction of Salmonella on chicken carcasses by immersion treatments. J. Food Prot. 48:939-943.

Mulder, R.W., Notermans, S. and Kampelmacher, E.H. 1977. Inactivation of salmonellae on chilled and deep frozen broiler carcasses by irradiation. J. Appl. Bacteriol. 42:179-185.

Nagaraja, K.V. and Back, A. 1998. Vaccination against Salmonella infection: Killed and subunit vaccines. Proc. Intl. Symp. on Food-borne Salmonella in Poultry. pp. 194-200. Baltimore, Maryland.

Nagaraja, K.V., Kim, C.J. and Pomeroy, B.S. 1988. Outermembrane proteins in prophylactic vaccines for Salmonella. J. Am. Vet. Med. Assoc. 192:1784.

Nagaraja, K.V., Kumar, M.C., Newman, J.A. and Pomeroy, B.S. 1985. Control of Salmonella arizonae infection in turkey breeding flocks by immunization. J. Am. Vet. Med. Assoc. 187:309.

Nagaraja, K.V., Newman, J.A. and Pomeroy, B.S. 1984. Use of oil adjuvant vaccines for the control of Salmonella infections in turkeys. Proc. Intl. Symp. on Salmonella. 90:84-87.

Nagaraja, K.V., Pomeroy, B.S., Newman, J.A. and Peterson, I. 1982. Vaccination of turkeys with killed oil adjuvant Salmonella san-diego vaccine. J. Am. Vet. Med. Assoc. 181:284.

Nagaraja, K.V., Pomeroy, B.S. and Williams, J.E. 1991. Paratyphoid infections. In: Diseases of Poultry, $9^{\text {th }}$ Ed. Eds. B.W. Calnek, H.J. Barnes, C.W. Beard, W.M. Reid and H.W. Yoder, Jr. pp 99-130. Iowa State University Press, Ames, Iowa.

National Advisory Committee on Microbiological Criteria in Foods. 1997. Generic HACCP application in broiler slaughter and processing. J. Food Prot. 60:579-604.

National Advisory Committee on Microbiological Criteria for Foods. 1998. Hazard analysis and critical control point principles and application guidelines. J. Food Prot. 61:762-775.

Nisbet, D.J., Corrier, D.E., Ricke, S.C., Hume, M.E., Byrd II, J.A. and Deloach, J.R. 1996. Maintenance of biological efficacy in chicks of a cecal competitive-exclusion culture against Salmonella by continuous-flow fermentation. J. Food Prot. 59:1279-1283.

Nisbet, D.J., Tellez, G.I., Lowry, V.K., Anderson, R.C., Garcia, G., Nava, G., Kogut, M.H., Corrier, D.E. and Stanker, L.H. 1998. Effect of commercial competitive exclusion culture (Preempt ${ }^{\mathrm{TM}}$ ) on mortality and horizontal transmission of Salmonella gallinarum in broiler chickens. Avian Dis. 42:651-656. 
North, M.O. and Bell, D.D. (Eds.) 1990. Commercial chicken production manual. Forth Edition. pp 777-848. Chapman and Hall, New York.

Notermans, S. and Kampelmacher, E.H. 1974. Attachment of some bacterial strains to the skin of broiler chickens. Br. Poultry Sci. 15:573-585.

Novick, R.P. 1981. The development and spread of antibiotic-resistant bacteria as a consequence of feed antibiotics to livestock. Ann. N.Y. Acad. Sci. 368-:23-59.

Nurmi, E. and Rantala, H. 1973. New aspects of Salmonella infection in broiler production. Nature 241:210-211.

Olesiuk, O., Carlson, V., Snoeyenbos, G. and Smyser, C. 1969. Experimental Salmonella typhimurium infection in two chicken flocks. Avian Dis. 13:500-508.

Olesiuk, O., Snoeyenbos, G.H. and Smyser, C. 1971. Inhibitory effect of used litter on Salmonella typhimurium transmission in the chicken. Avian Dis. 15:118-124.

Opara, O.O., Carr, L.E., Russek-Cohen, E., Tate, C.R., Mallinson, E.T., Miller, R.G., Steward, L.E., Johnston, R.W. and Joseph, S.W. 1992. Correlation of water activity and other environmental conditions with repeated detection of Salmonella contamination on poultry farms. Avian Dis. 36:664-671.

Oyofo, B.A., Droleskey, R.E., Norman, J.O., Mollenhauer, H.H., Ziprin, R.L., Corrier, D.E. and DeLoach, J.R. 1989a. Inhibition by mannose of in vitro colonization of chicken small intestine by Salmonella typhimurium. Poultry Sci. 68:1351-1356.

Oyofo, B.A. DeLoach, J.R., Corrier, D.E., Norman, J.O., Ziprin, R.L. and Mollenhauer, H.H. 1989b. Prevention of Salmonella typhimurium colonization of broilers with D-mannose. Poultry Sci. 68:1357-1360.

Pacer, R.E., Spika, J.S., Thurmond, M.C., Hargett-Bean, N. and Potter, M.E. 1989. Prevalence of Salmonella and multiple antimicrobial-resistant Salmonella in California dairies. J. Am. Vet. Med. Assoc. 195:59-63.

Palmu, L. and Camelin, I. 1997. The use of competitive exclusion in broilers to reduce the level of Salmonella colonization on the farm and at the processing plant. Poultry Sci. 76:1501-1505.

Pivnick, H., Blanchfield, B. and D'Aoust, J.-Y. 1981. Prevention of Salmonella infection in chicks by treatment with fecal cultures from mature chickens (Nurmi cultures). J. Food Prot. 44:909-916.

Pivnick, H. and Nurmi, E. 1982. The Nurmi concept and its role in the control of Salmonella in poultry. In. Developments in Food Microbiology. Ed. R. Davis. pp 41-70. Applied Science Publisher Ltd., Essex, England. 
Polotsky, Y., Dragunsky, E. and Khavkin, T. 1994. Morphologic evaluation of the pathogenesis of bacterial enteric infections. Crit. Rev. Microbiol. 20:161-208.

Poppe, C., Barnum, D.A. and Mitchell, W.R. 1986. Effect of chlorination of drinking water on experimental Salmonella infection in poultry. Avian Dis. 30:362-369.

Pritchard, D.G., Nivas, S.C., York, M.D. and Pomeroy, B.S. 1978. Effect of Gal-E mutant of Salmonella typhimurium on experimental salmonellosis in chickens. Avian Dis. 22:562-575.

Reilly, W.J., Forbes, G.I., Patterson, G.M. and Sharp, J.C.M. 1981. Human and animal salmonellosis in Scotland associated with environmental contamination. Vet. Rec. 108:553-555.

Rivault, C., Cloarec, A. and Leguyader, A. 1993. Bacterial load of cockroaches in relation to urban environment. Epidemiol. Infect. 110:317-321.

Robach, M.C. and Sofos, J.H. 1982. Use of sorbates in meat products, fresh poultry and poultry products: A review. J. Food Prot. 45:374-383.

Rosales, A.G. and Jensen, E.L. 1998. Biosecurity and disinfection for Salmonella control. Proc. Intl. Symp. on Food-borne Salmonella in Poultry. pp. 105-117. Baltimore, Maryland.

Rouse, J., Rolow, A. and Nelson, C.E. 1988. Effect of chemical treatment of poultry feed on survival of Salmonella. Poultry Sci. 67:1225-1228.

Russell, S.M. 1996. Escherichia coli: The unreliable index? Broiler Industry 10:20-24.

Russell, S.M. 1998. The effect of poultry processing steps on populations of bacteria on fresh broiler chicken carcasses. Proc. Intl. Symp. on Food-borne Salmonella in Poultry. pp. 232-236. Baltimore, MD.

Salvat, G., Poppen, P., Allo, J.C., Fenner, S., Laisney, M.J., Toquin, M.T., Humbert, F. and Colin, P. 1997. Effects of AvGard ${ }^{\mathrm{TM}}$ treatment on the microbiological flora of poultry carcases. Br. Poultry Sci. 38:489-498.

Samuelson, K.J., Rupnow, J.H. and Frowning, G.W. 1985. The effect of lysozyme and ethylenediaminetetraacetic acid and Salmonella on broiler parts. Poultry Sci. 64:1488-1490.

Sanderson, K., Thomas, C.J. and McMeekin, T.A. 1991. Molecular basis of the adhesion of Salmonella serotypes to chicken muscle fascia. Biofouling 5:89-101.

Savage, D.C. 1987. Factors influencing biocontrol of bacterial pathogens in the intestine. Food Technol. 41:82-87.

Schwach, R.S. and Zottola, E.A. 1982. Use of scanning electron microscopy to demonstrate microbial attachment to beef and beef contact surfaces. J. Food Sci. 47:1401-1405. 
Sheldon, B.W. and Brown, A.L. 1986. Efficacy of ozone as a disinfectant for poultry carcasses and chill water. J. Food Sci. 51:305-309.

Simmons, G.C. and Byrnes, R.V. 1972. The origin of Salmonella in chickens and chicken carcasses. Aust. Vet. J. 48:186-189.

Smith, D. 1997. Competitive exclusion making comeback. Turkey World 41:30-31.

Smith, P.J., Boardman, A. and Shutt, P.C. 1989. Detection of Salmonella in animal feeds by electrical conductance. J. Appl. Bacteriol. 67:575-588.

Snijders, J.M.A., van Logtestijn, J.G., Mossel, D.A.A. and Smulders, F.J.M. 1985. Lactic acid decontaminant in slaughter and processing procedures. Vet. Q. 7:277-282.

Snoeyenbos, G.H., Carlson, V.L., McKie, B.A. and Smyser, C.F. 1967. An epidemiological study of salmonellosis of chickens. Avian Dis. 11:653-667.

Snoeyenbos, G.H., Carlson, V.L., Smyse, C.F. and Olesuik, O.M. 1969. Dynamics of Salmonella infection in chicks reared on litter. Avian Dis. 13:72-83.

Snoeyenbos, G.H., McKie, B.A., Smyser, C.F. and Weston, C.R. 1970. Progress in identifying and maintaining Salmonella-free commercial chicken breeding flocks. Avian Dis. 14:683-696

Snoeyenbos, G.H., Soerjadi, A.S. and Weinack, O.M. 1982. Gastrointestinal colonization by Salmonella and pathogenic Escherichia coli in monozenic and holoxenic chicks and poults. Avian Dis. 26:566-575.

Snoeyenbos, G.H., Weinack, O.M. and Smyser, C.F. 1978. Protecting chicks and poultry from salmonellae by oral administration of "normal" gut microflora. Avian Dis. 22:273-287.

Soerjadi, A.S., Druitt, J.H., Llyod, A.B. and Cumming, R.B. 1979. Effect of environmental temperature on susceptibility of young chickens to Salmonella typhimurium. Aust. Vet. J. 55:413-417.

Solberg, M., Miskimin, D.K., Martin, B.A., Page, G., Goldner, S. and Libfeld, M. 1977. Indicator organisms: Food borne pathogens and food safety. Assoc. Food Drug Off. Quart. Bull. 41:9-21.

Spika, J.S., Waterman, S.H., Soo Hoo, G.W., St. Louis, M.E., Pacer, R.E., James, S.M., Bissett, M.L., Mayer, L.W., Chiu, J.Y., Hall, B., Greene, K., Potter, M.E., Cohen, M.L. and Blake, P.A. 1987. Chloramphenicol-resistant Salmonella newport traced through hamburger to dairy farms. N. Eng. J. Med. 316:565-570.

Stavric, S. 1987. Microbial colonization control of chicken intestine using defined cultures. Food Technol. 41:93-98. 
Stavric, S. and D'Aoust, J. -Y. 1993. Undefined and defined bacterial preparations for the competitive exclusion of Salmonella in poultry - A review. J. Food Prot. 56:173-180.

Stersky, A., Blanchfield, B., Thacker, C. and Pivnick, H. 1981. Reduction of Salmonella excretion into drinking water following treatment of chicks with Nurmi culture. J. Food Prot. 44:917-920.

Tamblyn, K.C. and Conner, D.E. 1997. Bactericidal activity of organic acids against Salmonella typhimurium attached to broiler chicken skin. J. Food Prot. 60:629-633.

Tamblyn, K.C., Conner, D.E. and Bilgili, S.F. 1997. Utilization of skin attachment model to determine the antibacterial efficacy of potential carcass treatments. Poultry Sci. 76:1318-1323.

Thaxton, P., Wyatt, R.D. and Hamilton, P.B. 1971. Cold stress and Salmonella as a cause of early mortality in chickens. Poulty Sci. 50:1636 (Abstr.)

Thayer, D. 1995. Use of irradiation to kill enteric pathogens in meat and poultry. J. Food Safety 15:181-192.

Thayer, D., Songprasertchai, S. and Boyd, G. 1991. Effects of heat and ionizing radiation on Salmonella typhimurium in mechanically deboned chicken meat. J. Food Prot. 54:718-724.

Thomas, C.J. and McMeekin, T.A. 1981. Attachment of Salmonella spp. to chicken muscle surfaces. Appl. Environ. Microbiol. 42:130-134.

Thomas, C.J. and McMeekin, T.A. 1984. Effect of water uptake by poultry tissues on contamination by bacteria during immersion in bacterial suspensions. J. Food Prot. 47:398-402.

Thomas, C.J., McMeekin, T.A. and Patterson, J.T. 1987. Prevention of microbial contamination in the poultry processing plant. In. Elimination of Pathogenic Organisms from Meat and Poultry. (Ed.) F.J.M. Smulders, pp 163-179. Elsiever, Amsterdam.

Thomson, J.E., Cox, N.A. and Bailey, J.S. 1977. Control of Salmonella and extension of shelf life of broiler carcasses with a glutaraldehyde product. J. Food Sci. 42:1353-1355.

Thomson, J.E., Bailey, J.S., Cox, N.A., Posey, D.A. and Carson, M.O. 1979. Salmonella on broiler carcasses as affected by fresh water input rate and chlorination of chiller water. J. Food Prot. 42:954-955.

Threfall, E.J., Ward, L.R. and Rowe, B. 1997. Increasing incidence of resistance to trimethoprim and ciprofloxacin in epidemic Salmonella typhimurium DT104 in England and Wales. Euro Surveillance 2:81-84.

Todd, E.C.D. 1980. Poultry-associated foodborne disease - its occurrence, cost, sources and prevention. J. Food Prot. 43:129-139. 
Tsai, L.S., Schade, J.E. and Molyneux, B.T. 1991. Chlorination of poultry chill water: chlorine demand and disinfection efficacy. Poultry Sci. 71:188-196.

Tucker, J.F. 1967. Survival of salmonellae in built-up litter for housing of rearing and laying fowl. Br. Vet. J. 123:92-103.

Turnbull, P.C.B. and Snoeyenbos, G.H. 1973. The roles of ammonia, water activity, and pH in the salmonellacidal effect of long-used poultry litter. Avian Dis. 17:72-86.

USDA. 1996. Pathogen reduction: Hazard analysis and critical control point (HACCP) systems. Final rule. 9 CFR Part 304. 61:38805-38989.

USDA-FSIS. 1996. How USDA's new food safety system will fight bacteria that cause food borne illness. Key Facts Bulletin. July.

van der Marel, G.M., van Logtestijn, J.G. and Mossel, D.A.A. 1988. Bacteriological quality of broiler carcasses as affected by inplant lactic acid decontamination. Int. J. Food Microbiol. $6: 31-42$.

Waldroup, A.L. 1998. Chemical control of microorganisms on raw poultry. Proc. Intl. Symp. on Food-borne Salmonella in Poultry. pp. 237-241. Baltimore, MD.

Walls, I., Cooke, P.H., Benedict, R.C. and Buchanan, R.L. 1993. Sausage casing as a model for attachment of Salmonella to meat. J. Food Prot. 56:390-394.

Wang, W-C., Li, Y., Slavik, M.F. and Xiong, H. 1997. Trisodium phosphate and cetylpyridinium chloride spraying on chicken skin to reduce attached Salmonella typhimurium.

J. Food Prot. 60:992-994.

Wathes, C.M., Zaiden, W.A.R., Pearson, G.R., Hinton, M. and Todd, N. 1988. Aerosol infection in calves and mice with Salmonella typhimurium. Vet. Rec. 123:590-594.

Williams, B.J. 1985. The effect of neomycin and oxytetracycline alone or combined upon the incidence of salmonellosis in broiler chickens. Poultry Sci. 64:1455-1457.

Williams, J.E. 1984. Paratyphoid infections. In: Diseases of Poultry. (Eds) M.S. Hofstad, H.J. Barnes, W.M. Reid and H.W. Yoder. pp 91-129. Iowa State University Press, Ames, Iowa.

Wray, C. and Davies, R.H. 1998. Environmental problems in poultry production: Dust and pests. Proc. Intl. Symp. on Food-borne Salmonella in Poultry. pp. 93-104. Baltimore, Maryland.

Xiong, H., Li, Y., Slavik, M.F. and Walker, J.T. 1998. Spraying chicken skin with selected chemicals to reduce attached Salmonella typhimurium. J. Food Prot. 61:272-275. 
Yang, P.P.W. and Chen, T.C. 1979. Stability of ozone and its germicidal properties on poultry meat microorganisms in liquid phase. J. Food Sci. 44:501-504.

Yang, Z., Li, Y. and Slavik, M. 1998. Use of antimicrobial spray applied with an inside-outside birdwasher to reduce bacterial contamination of prechilled chicken carcasses. J. Food Prot. 61:829-832. 
Table 1. Salmonella virulence factors and their mechanisms of action (D'Aoust, 1997).

\begin{tabular}{|c|c|c|}
\hline Virulent factors & Mechanism of action & Invasion genes \\
\hline Siderophores & $\begin{array}{l}\text { Compete with host transferrin, lactoferrin and } \\
\text { ferritin ligands for available iron }\end{array}$ & fur \\
\hline PhoP/PhoQ regulon & $\begin{array}{l}\text { Enables Salmonella to survive phagocytes, high } \\
\text { acidity of phagolysosomes and defensins }\end{array}$ & pag and prg \\
\hline $\begin{array}{l}\text { Toxins } \\
\text { A-B entertoxin, } \\
\text { cytotoxin }\end{array}$ & Fluid exsorption & stx \\
\hline Vi antigen & $\begin{array}{l}\text { Inhibiting opsonization of the } \mathrm{C} 3 \mathrm{~b} \text { host } \\
\text { complement factor on surface lipopolysaccharide }\end{array}$ & $v i a \mathrm{~A}$ and $v i a \mathrm{~B}$ \\
\hline $\begin{array}{l}\text { Enzymes } \\
\text { Catalase, superoxide } \\
\text { dismutase, peroxidase }\end{array}$ & Protection against singlet oxygen and $\mathrm{H}_{2} \mathrm{O}_{2}$ & oxy R \\
\hline Plasmid (30-60 Mda) & $\begin{array}{l}\text { Rapidly multiply the bacteria and spread } \\
\text { infection }\end{array}$ & $s p v$ \\
\hline $\begin{array}{l}\text { Porins (outer } \\
\text { membrane proteins) }\end{array}$ & Regulates influx of nutrients and antibiotics & $\begin{array}{l}o m p \mathrm{C}, o m p \mathrm{D}, \\
o m p \mathrm{E} \text { and } o m p \mathrm{~F}\end{array}$ \\
\hline Lipopolysaccharides & $\begin{array}{l}\text { Repels lytic attack of the host complement } \\
\text { system }\end{array}$ & - \\
\hline
\end{tabular}


Table 2. Sources of Salmonella (and other microorganisms) contamination during poultry processing (Russell, 1998).

\begin{tabular}{lcccc}
\hline \hline Operation & Workers hands & $\begin{array}{c}\text { Equipment and } \\
\text { tools }\end{array}$ & Bird to bird & $\begin{array}{c}\text { Other } \\
\text { environmental } \\
\text { factors }\end{array}$ \\
\hline Stunning & - & - & - & $*$ \\
Scalding & - & $* *$ & $* * *$ & $* * *$ \\
Picking & - & $* * * *$ & $* *$ & - \\
Washing & $* * *$ & $*$ & - & - \\
Rehanging & $* *$ & - & $* * *$ & - \\
Evisceration & $* * * *$ & $* * * *$ & - & - \\
Inspection & $* * * *$ & - & - & - \\
Reprocessing & - & $* * * *$ & - & $* * * *$ \\
Washing & - & $*$ & $* *$ & $* * * *$ \\
Chilling & $* * * *$ & - & - & - \\
Rehanging & - & - & $* * *$ & - \\
Sizing & $* * * *$ & $* *$ & $*$ & - \\
Boxing & & & & - \\
\hline \hline
\end{tabular}

${ }^{1}$ processing parameters, water quality, and disinfectant level

* not a significant source of contamination

$* * * *$ significant source of contamination 
Table 3. Salmonella-reduction performance standards ${ }^{1}$ in the U.S. poultry slaughter plants (Anon, 1996).

\begin{tabular}{lccc}
\hline \hline Class & $\begin{array}{c}\text { Performance } \\
\text { standards (\% positive) }\end{array}$ & $\begin{array}{c}\text { Number of samples } \\
\text { tested }\end{array}$ & $\begin{array}{c}\text { Maximum number of } \\
\text { positives to achieve } \\
\text { standard }\end{array}$ \\
\hline Broiler carcasses & 20.0 & 51 & 12 \\
Turkey carcasses & $18.6^{2}$ & Not available & Not available \\
Ground chicken & 44.6 & 53 & 26 \\
Ground turkey & 49.9 & 53 & 29 \\
\hline \hline
\end{tabular}

${ }^{1}$ Products cannot test positive at rates exceeding the above standards. Frequency and timing of testing will be based on the establishment's previous results and other performance criteria.

${ }^{2}$ McNamara and Levine, 1998 
Table 4. Escherichia coli control testing criteria in U.S. processing plants (Anon, 1996).

\begin{tabular}{|c|c|c|c|c|}
\hline \multirow[t]{2}{*}{ Class } & \multirow{2}{*}{$\begin{array}{l}\text { Sampling } \\
\text { frequency }\end{array}$} & \multirow[t]{2}{*}{ Procedure } & \multicolumn{2}{|c|}{ Acceptable limits ${ }^{\mathrm{a}}$} \\
\hline & & & $\begin{array}{c}\text { Lower limit (m) } \\
\mathrm{CFU}^{\mathrm{b}} / \mathrm{cm}^{2}\end{array}$ & $\begin{array}{l}\text { Upper limit (M) } \\
\mathrm{CFU} / \mathrm{cm}^{2}\end{array}$ \\
\hline Cattle & $\begin{array}{l}1 \text { sample/300 } \\
\text { carcasses }\end{array}$ & $\begin{array}{l}\text { Sponge flank, } \\
\text { rump, and brisket } \\
\text { from carcass in } \\
\text { the cooler }\end{array}$ & Negative $^{\mathrm{c}}$ & 100 \\
\hline Hogs & $\begin{array}{l}1 \text { sample/1,000 } \\
\text { carcasses }\end{array}$ & $\begin{array}{l}\text { Sponge ham, } \\
\text { belly, and jowls } \\
\text { from carcass in } \\
\text { the cooler }\end{array}$ & 10 & 10,000 \\
\hline Chickens & $\begin{array}{l}1 \text { sample/22,000 } \\
\text { carcasses }\end{array}$ & $\begin{array}{l}\text { Rinse whole bird } \\
\text { after the drip line }\end{array}$ & 100 & 10,000 \\
\hline Turkeys & $\begin{array}{l}1 \text { sample/3,000 } \\
\text { carcasses }\end{array}$ & $\begin{array}{l}\text { Rinse whole bird } \\
\text { after the drip line }\end{array}$ & Not available & Not available \\
\hline
\end{tabular}

${ }^{a}$ No result can exceed the upper limit $(\mathrm{M})$ and three or fewer sample are allowed between the lower limit (m) and the upper limit out of the most recent 13 samples.

${ }^{\mathrm{b}}$ Colony forming unit

${ }^{\mathrm{c}}$ Negative is defined by the sensitivity of the method to detect at least $5 \mathrm{CFU} / \mathrm{cm}^{2}$ 
Figure 1. An overview of the movement of Salmonella through the poultry chain (adapted from International Hatchery Practice and International Poultry Production Supplement).

Arrows indicate Salmonella movement; $\mathrm{D}=$ disinfection; $\mathrm{H}=$ heat treatment; $\mathrm{M}=$ monitoring;

$\mathrm{A}=$ acidification; $\mathrm{V}=$ vaccination; $\mathrm{Ve}=$ vaccination of egg layers only; $\mathrm{T}=$ test (if positive reject or reschedule); and $\mathrm{CE}=$ competitive exclusion. 


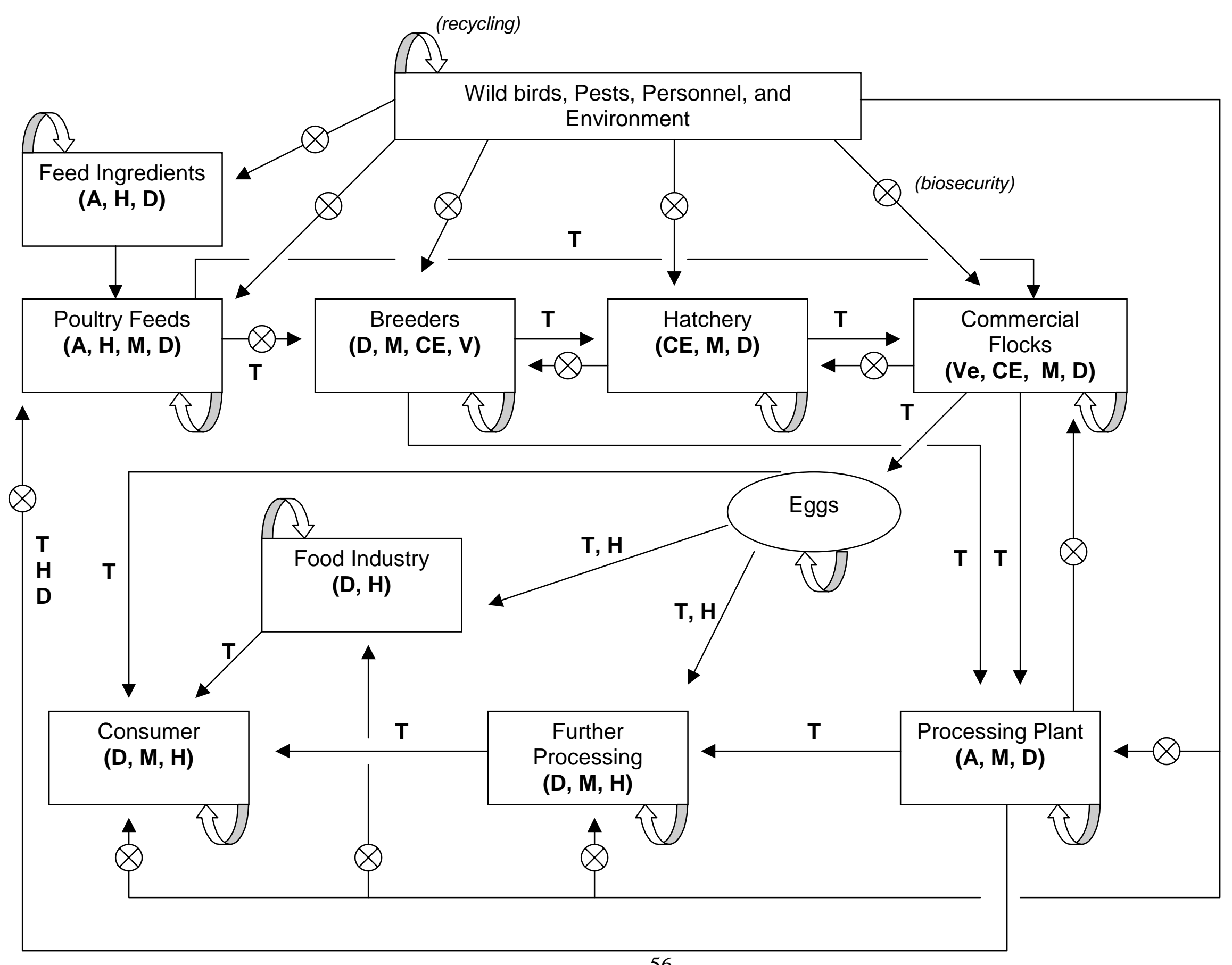


Figure 2. Critical control points for whole carcass processing of poultry salmonellosis (McCapes et al., 1991). 


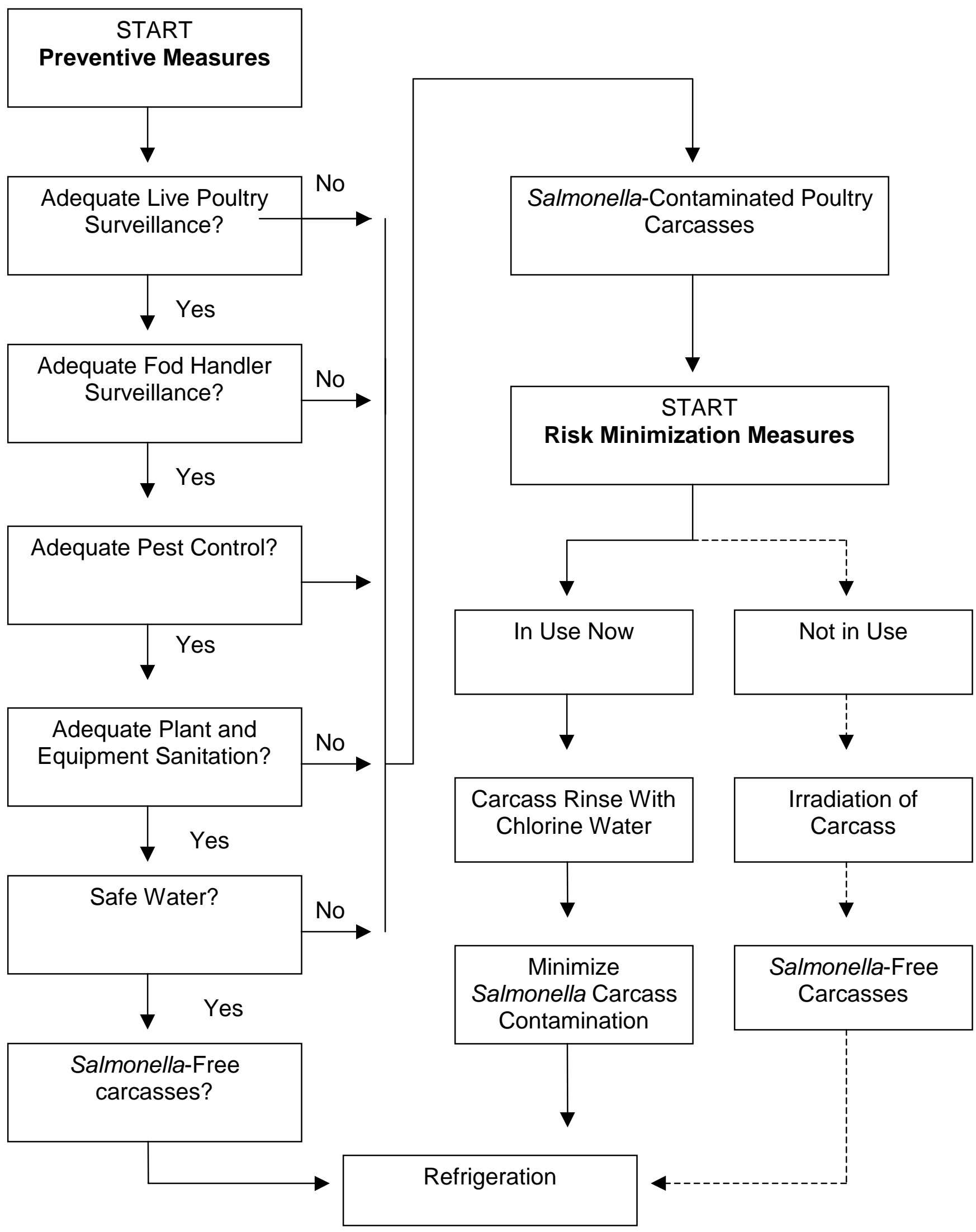


CHAPTER 1

DYNAMICS OF SALMONELLA COLONIZATION IN A TURKEY

PRODUCTION FACILITY 


\begin{abstract}
A comprehensive ecological survey was conducted from April 1997 to June 1999 on four turkey flocks (F5 to F8) to identify the key preharvest sources of Salmonella colonization. This study was part of an ongoing survey conducted to evaluate the frequency of Salmonella contamination on a turkey production facility that has not been populated with poultry for over 20 years. Turkey cecal and crop contents, litter, drinkers, air, feed, and feeder contents were sampled. Environmental swabs were also collected throughout the facility. For each flock, 5 to 12 pens were sampled during each sampling period. Conventional microbiological and serological procedures were used to isolate, identify, and confirm the presence or absence of Salmonella. Isolates were serotyped and screened for antibiotic resistance. Salmonella was detected from $21 \%, 5 \%, 0 \%$, and $1 \%$ of the samples in F5, F6, F7, and F8, respectively. Overall, Salmonella was isolated from $13 \%$ of litter, $11 \%$ of turkey ceca, $10 \%$ of drinker, $5 \%$ of swab, $3 \%$ of feed, and $1 \%$ of feeder contents. Salmonella was not detected in crop and air samples. Salmonella heidelberg (65\%), S. senftenberg (19\%), S. muenster (10\%), S. anatum (3\%), and S. worthington (3\%) were the serotypes isolated from the sampled sources and flocks. Of the 69 serotypes screened, $25 \%$ of the Salmonella isolates were resistant to the following antibiotics: gentamycin, spectinomycin, tetracycline, tobramycin, and trimethoprim/sulfamethoxazole. Identifying environmental sources associated with Salmonella colonization and characterizing serotypes and antibiograms would assist in designing preharvest controls for this poultry-borne pathogen. Integrators and poultry producers may be able to design hazard analysis and critical control point (HACCP) protocols to reduce the level of Salmonella arriving at the processing plant.
\end{abstract}


KEY WORDS: antibiotics, preharvest sources, Salmonella, serotypes, turkey 


\section{INTRODUCTION}

Salmonella contamination has been a persistent problem affecting the poultry industry in the United States. Annual productivity losses and medical costs due to salmonellosis are estimated from $\$ 0.6$ billion to $\$ 3.5$ billion (Opitz et al., 1993; Buzby et al., 1996). The poultry industry processes over eight billion broiler-hatching eggs through commercial hatcheries each year (Cox, 1998). Much of the traceable human Salmonella enteritidis infection has been caused by consumption of egg or poultry products (Bailey, 1993). Poultry meat has been implicated in a large number of salmonellosis cases in humans. Salmonella colonizes the intestinal tract of poultry causing contamination of carcasses during processing. The incidences of Salmonella contamination among broiler carcasses has been found to vary from 5 to $100 \%$ (Carraminana et al., 1997). The Food Safety and Inspection Services conducted a nationwide survey (1992-1998) from federally inspected plants to generate microbiological baseline data (McNamara and Levine, 1998). Establishments sampled in the program accounted for approximately $99.9 \%$ of all broiler and turkeys slaughtered in the US, and they produced 100\% of ground chicken and turkey product. The study found that Salmonella was prevalent in broiler carcass rinses (20\%), turkey carcass rinses (18.6\%), raw ground chicken (44.6\%), and raw ground turkey meat $(49.9 \%)$.

Reduction of Salmonella in poultry requires comprehensive control at the farm where birds are brooded and raised before shipment to processing plants. Chicks are very susceptible to Salmonella infection and gut colonization from hatching to $96 \mathrm{~h}$ of age (Bailey, 1988). These chicks can be infected by vertical transmission through infected parents or by horizontal transmission through hatcheries, sexing in contaminated hatcheries, cloacal infection, transportation equipment, and feed (Lahellec and Colin, 1985; Opitz et al., 1993). 
Environmental factors such as air, litter, and unclean facilities, and vectors such as insects, humans, and rodents are also responsible for Salmonella transmission in poultry (Jones et al., 1991; Bailey, 1993; Hoover et al., 1997). Once sources are identified, critical control points can be established at the farms to control horizontal and vertical transmission of Salmonella. A reduction in Salmonella-positive birds will reduce public health risks associated with poultry products (Simmons and Byrnes, 1972).

Although research has been carried out on Salmonella ecology in chickens (Simmons and Byrnes, 1972; Bains and MacKenzie, 1974; Snoeyenbos et al., 1974; Dougherty, 1976; Morgan-Jones, 1980; Bhargava et al., 1983; Lahelec and Colin, 1985; Jones et al., 1991; Bailey, 1993), limited information is available on turkey flocks (Kumar et al., 1971; Hoover et al., 1997; Amick-Morris, 1998). Additionally, rearing turkeys differs from rearing chickens. The production cycle of turkeys is 20 to 22 weeks compared to 6 to 8 weeks in broilers. An ecological survey was conducted on turkey flocks to:

1. Identify key environmental sources/vectors influencing Salmonella colonization dynamics in a turkey production facility;

2. Characterize Salmonella isolates for serotype and antibiotic resistance patterns;

3. Evaluate the role of temperature and humidity within the production facility, and litter $\mathrm{pH}$ and water activity (Aw) on Salmonella colonization among sampled flocks and;

4. Monitor sex effect on resistance to Salmonella colonization.

\section{MATERIALS AND METHODS}

\section{Production parameters}

Facility: This survey was conducted at Reymann Memorial Farm, Wardensville, WV, in partnership with British United Turkeys of America (BUTA), Lewisburg, WV. The farm has 
been used for beef and sheep production, and it had not been populated with chickens or turkeys for over 20 years prior to initiation of survey work (Hoover et al., 1997). Prior to this study, production trials of three turkey flocks were carried out by BUTA and frequency of Salmonella was monitored (Amick-Morris and Kenney, 1997; Guo et al., 1997; Hoover et al., 1997). The facility consists of 24 pens divided equally by the service area (Fig. 1). The dimensions of each pen were $3.6 \mathrm{~m}$ (width) x $4.2 \mathrm{~m}$ (length) x $2.4 \mathrm{~m}$ (height). Four consecutive turkey flocks (F5F8) were sampled in this facility from April 1997 to June 1999 . These were the $5^{\text {th }}, 6^{\text {th }}, 7^{\text {th }}$, and $8^{\text {th }}$ flocks produced in this facility. Flock characteristics and responses measured are summarized in Table 1. Biosecurity measures were in accordance with BUTA guidelines (Appendix). Before placement of each new flock, used litter was removed, pens and equipment were disassembled, and the production facility was thoroughly cleaned and disinfected to prevent cross contamination from the previous flock. Fresh litter was added to the pens before placement of new poults in each flock.

Production trials: BUTA trials evaluated effects of strain, gender, and nutrition on growth performance, feed efficiency, and carcass composition of turkeys among sampled flocks. In F5, a strain $\mathrm{x}$ gender combination was replicated twice and randomly assigned to the 24 pens. Treatment main effects consisted of six breeds $(78 \times 12,78 \times 25,38 \times 71,72 \times 12,72 \times 71$, and $72 \times 25)$ and two genders (male and female). One hundred and fifty male and 150 female poults for each of 12-treatment combination were placed in a brooding ring ( $3.6 \mathrm{~m}$ diameter). Poults were hatched at the BUTA hatchery in Lewisburg, WV, and transported to the Rocco Farms hatchery in Harrisonburg, VA, to be de-toed. Turkeys from each flock were brooded for a 2-week period, after which the poults were assigned to their respective rearing pens (Table 2). Diet formulation, feeding schedule, and flock densities were not available for this flock. 
In F6, a strain $\mathrm{x}$ feed combination was replicated four times and randomly assigned to the 24 pens. Treatments main effects consisted of three strains of male turkeys (Big 6, Hybrid, and Nicholas) and two feeding regimens (BUTA-USA feeding program and European High Protein feeding program). Ration formulations and feeding programs are shown in Table 3. Two hundred and fifty poults for each of 6-treatment combination were placed a brooding ring. Approximately 50 poults were placed in assigned pens.

In F7, a strain $\mathrm{x}$ feed combination was replicated three times and randomly assigned to the 24 pens. Treatment main effects consisted of four strains of female turkeys (Big 6, Hybrid, Nicholas, and Line 37) and two feeding regimens (Heavy Hen feeding program and Least Cost Hen feeding program). Ration formulation and feeding program are shown in Table 4. Two hundred and fifty poults for each of 8-treatment combination were placed in a brooding ring. Approximately 70 poults were placed in assigned pens.

In F8, a strain $\mathrm{x}$ gender combination was replicated three times and randomly assigned to the 24 pens. Treatment main effects consisted of four strains of turkeys (Big 6, Hybrid, Nicholas, and 37-Roaster) and two genders (male and female). The composition of feed is shown in Table 5. Two hundred and twenty five female poults and 175 male poults for each of 8-treatment combinations were placed in a brooding ring. Approximately 70 female and 55 male poults were placed in assigned pens.

\section{Sampling procedures}

Litter, drinker, air, feed samples, and environmental swabs were collected for each flock throughout the grow-out period (Table 1). Litter, drinkers, and turkeys were sampled from the same pen. Turkeys were sacrificed by cervical disarticulation in accordance with approved animal care and use procedures (AVMA, 1993). 
Turkeys: At day 0 , poults arrived from a commercial hatchery within $24 \mathrm{~h}$ of hatch. Cardboard liners were sampled by removing three, $16 \mathrm{~cm}^{2}$ areas with a sterile scalpel and transferring them to $100 \mathrm{~mL}$ Universal Preenrichment (UP) broth (Bailey and Cox, 1992). Liners were sampled only for F7. Samples were collected from boxes that represented three different hatcheries in which the birds were shipped. Four boxes were randomly sampled from each hatchery. In F7, 12 poults from three hatcheries were sacrificied by cervical disarticulation at day 0 , and the entire intestine and yolk sacs were transferred to $100 \mathrm{~mL}$ UP broth. After two weeks of brooding, 24 poults were sampled from 12 brooding rings in F5, 16 poults from 8 brooding rings in F7, and 16 poults from 8 brooding rings in F8. For F6, sample collection began from week 6 (Table 1). At week 2, intestinal samples were transferred to $100 \mathrm{~mL}$ UP broth among the sampled flocks. From week 10 until the end of the grow-out period, the entire ceca were removed, the blind end was snipped with sterile scissors, and cecal contents were emptied into sterile stomacher bags and sealed. Bottles containing UP broth and stomacher bags were held on ice during transport to the laboratory for Salmonella testing. Crop contents were sampled in F7 and F8 by removing the crop, making an incision with a sterile scalpel and transferring the contents into a sterile stomacher bag. This bag was sealed and shipped to the laboratory on ice for further analysis.

Litter: Litter samples consisted of a composite sample collected from six random locations within each pen. Samples were collected from the top $5.08 \mathrm{~cm}$ of litter preferably mixed with bird feces. Litter samples were placed in sterile bags and held on ice during transport to the laboratory.

Drinkers: At each sampling period, one Plasson drinker in each of the designated pens was sampled. Drinkers were swabbed with 2 or 3 ply sterile cloth gauzes $\left(5 \times 5 \mathrm{~cm}^{2}\right)$ held by a 
pair of sanitized forceps. Samples were placed in sterile stomacher bags, and bags were sealed and held on ice during transport to the laboratory.

Environmental swabs: Samples were collected from a $16 \mathrm{~cm}^{2}$ area at various locations in the facility using a sterile swab moistened with sterile UP broth. Locations included walls, ventilation fans, feathers and open wounds of sick birds, feathers of dead birds, employee shoes, the feed truck, fans inside the pens, feed storage bins, and door handles. Swabs were transferred to $10 \mathrm{~mL}$ sterile UP broth and held on ice during transport to the laboratory.

Air: Samples were collected on Rodac plates $(65$ x 15 mm) containing Brain Heart Infusion (BHI) agar using a SAS portable high flow air-sampler (Model 5203, Spiral Biotech, Inc., Maryland). The air sampler was set to collect 60 liters of air in $20 \mathrm{~s}$, allowing impingement of airborne microorganisms on the Rodac plate (Al-Dagal and Fung, 1993; Hoover et al., 1997). The air sampler cover was sanitized with $70 \%$ ethyl alcohol before reuse. Following sampling, the agar was aseptically transferred to sterile stomacher bags, sealed, and held on ice during transport to the laboratory. Air samples were collected from pens, ventilation fans, alleys on each side of the turkey house, the centralized service area, and entrances to the facility during each sampling period (Fig. 1).

Feed and feeder contents: Samples were collected randomly from each feed shipment by placing a sterile bag in the flow of feed from the auger or from the feed cart. Feeder contents were sampled from each of 24 pens every Friday of production for each flock. Samples were stored at $-4^{\circ} \mathrm{C}$ at the production facility prior to transport to the laboratory for analyses. Approximately 10 to $20 \%$ of the feed weigh-back samples were analyzed during each sampling period. 


\section{Laboratory procedures}

Turkey cecal and crop samples, placed in stomacher bags, were mixed with UP broth in a 1:10 (w/v) ratio and were sealed. Gauze and agar from drinker and air samples, respectively, were mixed with $100 \mathrm{~mL}$ UP broth. Approximately $5 \mathrm{~g}$ of litter and $10 \mathrm{~g}$ of feed or feeder content samples, respectively, were transferred to bottles containing $100 \mathrm{~mL}$ UP broth using sterile gloves. Samples were thoroughly mixed with UP broth and incubated (Imperial II Incubator 422 , Labline Instrument Inc., Illinois) at $37^{\circ} \mathrm{C}$ for $24 \mathrm{~h}$. One $\mathrm{mL}$ of this preenriched sample was transferred to $9 \mathrm{~mL}$ of tetrathionate (TT) broth and incubated at $37^{\circ} \mathrm{C}$ for $24 \mathrm{~h}$. Selectively enriched samples from TT broth were streaked to isolation on Xylose Lactose Tergitol (XLT4) plates for F5, F6, and F7. Due to the unavailability of tergitol supplement in XLT4 for detecting Salmonella in F8, Xylose Lactose Desoxycholate (XLD) plates were used. These plates were incubated at $37^{\circ} \mathrm{C}$ for $24 \mathrm{~h}$. A single presumptive positive, Salmonella colony (black colony on XLT4/XLD plate), per sample, was stabbed and streaked on Triple Sugar Iron (TSI) and Lysine Iron agar (LIA) slants, respectively, using the same inoculating loop. The TSI and LIA slants were incubated at $37^{\circ} \mathrm{C}$ for $24 \mathrm{~h}$ and $48 \mathrm{~h}$, respectively. Salmonella-positive, TSI tubes could be identified by a red slant and black butt while LIA tube exhibited a purple slant and black butt. The above transfers were carried out under aseptic conditions in a laminar flow hood (Model NU-425-400, Class II Type A/B3, NuAire ${ }^{\mathrm{TM}}$ Inc., Minnesota).

Serology: At least 2 to 3 positive isolates, identified by TSI or LIA, were maintained on BHI agar slants and incubated at $37^{\circ} \mathrm{C}$ for $24 \mathrm{~h}$. Serology was performed on fresh (18-24 h) BHI cultures using Salmonella O (Group A-E; Vi) polyvalent antisera (BBL-Becton Dickenson Microbiological Systems, Maryland) to confirm the presence of Salmonella. Using a sterile inoculating loop, sufficient bacterial growth from the BHI slant was gently mixed with $0.5 \mathrm{~mL}$ 
saline $(0.85 \% \mathrm{NaCl})$. A drop of this bacterial suspension was placed on a glass slide and mixed with a drop of polyvalent antisera. The mixture was gently rocked for 1 min and agglutination was observed. A positive control of S. typhimurium and a negative control of Escherichia coli were used to eliminate false-positive readings.

Storage: Salmonella cultures, confirmed by serology, were transferred to 5-10 mL UP broth and incubated at $37^{\circ} \mathrm{C}$ for 18 to $24 \mathrm{~h}$. A loopful of this fresh culture was streaked to isolation on XLT4 plates and incubated at $37^{\circ} \mathrm{C}$ for 20 to $24 \mathrm{~h}$. A single Salmonella-positive black colony from each XLT4 plate was mixed in Micro-Protect tubes (TS/70-B, Technical Service Consultants Ltd., Lancashire, England) containing beads suspended in nutrient broth. These tubes were vertically shaken for $5 \mathrm{~s}$ and allowed to stand for at least $30 \mathrm{~s}$ allowing enough time for the bacterial suspension to be immobilized on the beads. Subsequently, nutrient broth from each tube was discarded using a sterile dropper and the tubes were stored at $-70^{\circ} \mathrm{C}$ until further use. This procedure was carried out under aseptic conditions in the laminar flow hood.

Serotyping: Salmonella isolates were removed from the freezer $\left(-70^{\circ} \mathrm{C}\right)$ and $1-2$ beads from each Micro-Protect tube were aseptically transferred to $5 \mathrm{~mL}$ of sterile UP broth. The tube was immediately placed back into $-70^{\circ} \mathrm{C}$ storage. Beads and broth were incubated at $37^{\circ} \mathrm{C}$ for 24 $\mathrm{h}$, and subsequently, a loopful of culture was streaked to isolation onto a XLT4 plate. A single black colony from XLT4 was streaked on BHI slant. Isolates were packed, labeled, and shipped to the Salmonella Reference Center at the University of Pennsylvania for serotyping and determining their antibiotic resistance profile, in accordance with the Interstate Shipments of Etiological Agents (42 CFR Part 72) regulations.

Environmental parameters: Litter $\mathrm{pH}$ and water activity (Aw) were measured, and temperature and relative humidity in the production facility were monitored as potential factors 
affecting frequency of Salmonella colonization (Hoover et al., 1997). For litter pH, about $10 \mathrm{~g}$ of litter were mixed with $100 \mathrm{~mL}$ distilled water in a stomacher bag and blended (Model 400, Tekmer, Ohio) at $230 \mathrm{rpm}$ for $30 \mathrm{~s}$. Sample $\mathrm{pH}$ was measured with a pH meter (Model 350, Corning Inc., New York). Water activity was measured in duplicate. The Aw meter (Model AquaLab CX2, Decagon Devices, Inc., Washington) was calibrated with $6 \mathrm{M} \mathrm{NaCl}(\mathrm{Aw}=0.76)$ before measuring samples. Maximum and minimum temperatures inside and relative humidity within the production facility were recorded using temperature and relative humidity sensors (Model ART.NR, Fancom Corp., Netherlands).

\section{RESULTS AND DISCUSSION}

\section{Frequency of detection}

In any microbiological survey, it is the important to select a suitable isolation/detection procedure for the targeted organism. A negative result does not necessarily indicate the absence of Salmonella in the sources sampled. Inability to detect Salmonella could be due to poor sensitivity of the isolation/detection procedure. In some cases, isolates may be viable but nonculturable. In any case, a sample may still harbor enough cells to transmit Salmonella infection among turkeys even though organisms were non-detectable (Amick-Morris, 1998).

Of the 991 samples in the survey, $6 \%$ were positive for Salmonella. Prevalence of Salmonella across all samples was found to vary from 0 to $21 \%$ among the sampled flocks. McBride and coworkers (1978) observed considerable flock to flock variation (0 to 72\%) among broiler breeds with one-third of the flocks having greater than $10 \%$ infection. In the present study, Salmonella was isolated from $13 \%$ of litter samples, $11 \%$ of turkey ceca, $10 \%$ of drinkers, $5 \%$ of environmental swabs, $3 \%$ of feed, and $1 \%$ of feeder contents. Salmonella was not detected in turkey crop and air samples. Isolation of Salmonella from litter samples, drinkers, 
feed samples, and feeder contents was evidence of the cross-contamination that occurred within the production facility. A survey conducted by Kumar and coworkers (1971) on three turkey flocks demonstrated that hatcheries, breeder flocks, and environmental sources such as litter, dust, water, and feed were the major sources of Salmonella contamination. Jones and coworkers (1991) surveyed two broiler houses for Salmonella contamination. Salmonella was isolated from $20.8 \%$ of feed mills, $13 \%$ of breeder houses, $7.1 \%$ of hatcheries, $4.5 \%$ of broiler houses, and $16.1 \%$ of processing plants and $13 \%$ of insects and $5.3 \%$ of mice collected at the grow-out facility. Among the sources sampled within the broiler houses, authors detected Salmonella in $4.3 \%$ of dead bird rinses, $2.4 \%$ of environmental swabs, and $5.2 \%$ of fecal droppings. Hoover and coworkers (1997) reported that $63.8 \%$ of drinkers, $53.8 \%$ of turkey ceca, $51.1 \%$ of litter, $39.1 \%$ of feeder contents, $22.8 \%$ of air, and $14.8 \%$ of feed were positive for the presence of Salmonella in two turkey flocks.

In F5, $21 \%$ of the 218 samples were positive for the presence of Salmonella (Table 6). Salmonella was isolated from $31 \%$ of turkey ceca, $28 \%$ of drinkers, $25 \%$ of litter samples, and $12 \%$ of environmental swabs. Salmonella was not detected in air and feed samples. Shedding of Salmonella by turkeys in feces could result in contamination of litter, drinkers, and feeder contents. Simmons and Byrnes (1972) found that $92 \%$ of the 56 litter samples isolated from two chicken flocks were contaminated with one or more Salmonella serotypes. Drinkers are a primary source of Salmonella transmission in poultry houses. Morgan-Jones $(1980 ; 1982)$ reported that water in drinkers was the major oral route of infection or re-infection among broilers during rearing. Morris and coworkers (1969) found identical serotypes of Salmonella from the feces of colonized birds and drinker samples. Feeder contents, within each pen, may be contaminated through turkey feces, feathers, and personnel working within the facility. These 
sources, in turn, could be responsible for propagating Salmonella transmission among birds. Frequency of Salmonella detection increased from $15 \%$ at week 2 to $47 \%$ at week 18 . Although temperature within the facility was not recorded, temperature fluctuations could stress turkeys, inducing them to shed Salmonella that might lead to increased rates of horizontal transmission. In F6, only 5\% of the 179 samples were Salmonella-positive (Table 7). Salmonella was isolated from $22 \%$ of litter, $8 \%$ of feed, and $4 \%$ of feeder content samples, and $3 \%$ of turkey ceca. Salmonella was not detected from drinkers, environmental swabs, and air samples. Feed and feeder contents have been reported to be the major sources of horizontal transmission of Salmonella in poultry houses (MacKenzie and Bains, 1976; Cox et al., 1983; Jones et al. 1991). Mcllroy (1998) reported that about 15\% of the feed samples tested positive for Salmonella. Although Salmonella was undetected at week 6, frequency of Salmonella decreased slightly from $8 \%$ at week 13 to $7 \%$ at week 21 . The decrease could be attributed to a qualitative and quantitative change in gut microflora that may inhibit Salmonella colonization in adult turkeys by competing for nutrients and attachment sites in the gastrointestinal tract. Barnes and coworkers (1972) showed that older birds were more resistant to intestinal colonization by Salmonella due to a mature gut microflora.

In F7, Salmonella could not be detected in any of the 361 samples (Table 8). Before placement of the poults in F7 (Day 0), litter, drinkers, air, feed, and environmental swabs were collected from various locations in the facility to determine the initial level of contamination. Poults entering the facility and box liners in which the poults were shipped were sampled as an indication of the level of Salmonella contamination acquired from the breeder flocks or the hatchery. Mayes and Takeballi (1983) reported that Salmonella might either contaminate young chicks directly through ovarian transmission or penetrate the shell membrane after the egg is 
laid. Once Salmonella transverses the membrane, it is very difficult to remove and destroy them or prevent their further invasion of the egg contents and developing embryo (Cason et al. 1994). Day-old, Salmonella-free poults may be contaminated in the rearing house by the environment, feed, water, or litter samples. Simmons and Byrnes (1972) reported that day-old chicks, feed, and litter were the major sources of Salmonella contamination for chicken carcasses sampled from two flocks. In order to prevent horizontal transmission of Salmonella, it is imperative that poults entering the turkey house are free from Salmonella. Hoover and coworkers (1997) reported $18.1 \%$ of poult box liners and $25 \%$ of yolk sac samples were positive for the presence of Salmonella in two sampled flocks. Elsewhere, Jones and coworkers (1991) could detect Salmonella in $9.4 \%$ of chick yolk sac and $7.1 \%$ of hatcheries in a survey of 2 integrated broiler firms.

In F8, only $1 \%$ of the 233 samples were Salmonella-positive (Table 9). Salmonella was isolated from $6 \%$ of environmental swabs, $5 \%$ of litter, and $3 \%$ each of turkey ceca and feeder content samples. Salmonella could not be detected in turkey crops, drinkers, air, and feed samples. Reduced detection of Salmonella in F6 (5\%), F7 (0\%), and F8 (1\%) could be attributed to Terminate ${ }^{\mathrm{TM}}$, a formaldehyde-based feed additive, administered to turkeys.

\section{Distribution of serotypes}

A total of 69 isolates were serotyped from 58 Salmonella-positive samples in F5, F6, and F8 (Table 10). Salmonella heidelberg was the most prevalent serotype, accounting for $65 \%$ of the isolates from these flocks. Other serotypes were identified as S. senftenberg (19\%), S. muenster (10\%), S. anatum (3\%), and S. worthington (3\%). Of the 48 isolates serotyped in F5, 92\% were S. heidelberg, $4 \%$ S. muenster, and $4 \%$ S. anatum (Table 11). Salmonella heidelberg was isolated from turkey ceca (46\%), drinkers (23\%), litter samples (21\%), and environmental 
swabs (10\%). Turkey ceca appeared to be the reservoir for S. heidelberg, and it may have been responsible for transmitting this serotype to litter and drinker samples. Differentiating $S$. heidelberg using genotypic methods would be useful in confirming the transmission pattern. In order to prevent $S$. heidelberg from entering the ecosystem of the production facility, control measures should be directed towards reducing this serotype in turkeys and not towards environmental vectors. Salmonella muenster was isolated from litter samples, drinkers, and environmental swabs, while $S$. anatum could be detected only in drinkers. Since $S$. muenster and S. anatum were detected only in litter and drinker samples, control measures should be implemented on these vectors, and not on the turkeys, because these vectors were responsible for propagation of these serotypes within the production facility. Of the 16 isolates serotyped in F6, $81 \%$ were S. senftenberg, $13 \%$ S. worthington, and 6\% S. heidelberg (Table 12). Salmonella senftenberg was isolated primarily from turkey ceca (6\%), litter (50\%), and feed samples (25\%), indicating that these vectors could serve as critical control points. Salmonella worthington was isolated from litter (6\%) and feeder content samples (6\%), while S. heidelberg was isolated from $6 \%$ of litter samples. Salmonella muenster was identified as the serotype for all 5 isolates evaluated in F8. Salmonella muenster was detected in $20 \%$ of litter samples and $40 \%$ each of environmental swabs and feeder content samples.

Serotypes appeared flock and source specific. In F5, S. heidelberg (92\%) was the most prevalent serotype, while in F6 and F8, S. senftenberg (81\%) and S. muenster (100\%), respectively, were predominant. In F5, S. anatum was associated with only drinkers. Salmonella heidelberg, which was a predominant serotype in F5, could be detected only from F6 litter samples. The presence of S. heidelberg in F6 indicates that this serotype could have been transmitted from F5. This observation could have been confirmed by differentiating $S$. 
heidelberg using genotypic methods such as plasmid finger printing, pulse field gel electrophoresis (PFGE), PCR-based typing or 16S ribotyping (Olsen et al., 1993; Threlfall et al., 1994). Serotypes were not identified using any such techniques in this study.

Serotype information can be valuable in designing control measures at the production facilities. If certain serotypes are consistently isolated from a particular farm, flock, or source, steps can be taken against those specific Salmonella strains in the production facility. Several studies have shown that Salmonella serotypes isolated from fully processed broiler carcasses originated from hatcheries, breeder flocks and/or broiler houses (Bhatia and McNabb, 1980; Bhargava et al., 1983; Lahellec and Colin, 1985; Goren et al., 1988; Jones et al., 1991). In a survey conducted by Bhargava and coworkers (1983), S. kentucky, S. saint paul and S. infantis were the major serotypes isolated from three chicken flocks. Lahellec and Colin (1985) found $17.3 \%$ of hatcheries and $21.6 \%$ of chicken houses infected with Salmonella. Salmonella binza, S. infantis, S. saint paul, and S. schwarzengrund were detected from chicken viscera, environmental swabs, drinkers, litter, and feeder contents. In addition, S. coeln, S. heidelberg, S. montevideo, and S. saint paul were detected consistently in hatchery, grow-out, and processing facilities. Jones and coworkers (1991) reported that S. typhimurim (33\%) and S. heidelberg (13\%) were the most prevalent serotypes isolated from breeder houses, broiler houses, feed mills, hatcheries, and processing units. Elsewhere, S. agona (47\%), S. saint paul (26\%), and S. reading (16\%) were the most frequently detected from 25 sampled flocks (McBride et al., 1978). Morgan-Jones (1980) isolated S. senftenberg, S. agona, S. montevideo and S. infantis from water troughs, while S. senftenberg, S. agona, and S. infantis were isolated from litter samples from four broiler houses. 


\section{Antibiotic resistance profile}

Of the 69 Salmonella serotypes screened, 25\% were resistant to one or more antibiotics such as gentamycin (GM), spectinomycin (SPT), streptomycin (S), tetracycline (TE), tobramycin (TOB), and trimethoprim/sulfamethoxazole (SXT). Among the isolates screened, 100\% each of S. anatum and S. worthington, $29 \%$ of S. muenster, and $17 \%$ of S. heidelberg were resistant to the above antibiotics. In F5, F6, and F8, frequency of Salmonella serotypes resistant to antibiotic(s) was isolated from drinkers (55\%), swabs (43\%), feeder contents (33\%) turkey ceca (26\%), and litter samples (5\%) (Table 13).

Of the 48 isolates in F5, 27\% of serotypes were resistant to two or more antibiotics (Table 14). Two isolates of S. anatum from drinkers at week 2 were resistant to TE and S. Of the 6 isolates of $S$. heidelberg detected in turkey ceca at week 18, 5 isolates were resistant to $S$, SPT, and GM, while the remaining isolate was resistant to TE, S, SPT, and GM. During this sampling period, two isolates of S. heidelberg from drinkers were resistant to S, SPT, and GM and the remaining two were resistant to TE, S, SPT, and GM. One isolate of S. heidelberg isolated from an environmental swab at week 18 was resistant to TE and SXT. Antibiotic resistant strains of $S$. heidelberg isolated from drinker samples at week 18 could have been horizontally transmitted by turkeys. However, the origin of TE and S-resistant S. anatum in drinkers and TE and SXT-resistant S. heidelberg in environmental swab remains unclear. Of the 16 isolates in F6, 13\% of serotypes were resistant to TE (Table 15). At week 21 of the grow-out period, S. worthington, detected in litter and feeder content samples, was resistant to TE. Of the 5 isolates in F8, $40 \%$ of serotypes were resistant to TOB, S, SPT, and GM (Table 16). At week 20 of the grow-out period, two isolates of $S$. muenster, isolated from environmental swabs, were resistant to TOB, S, SPT, and GM. 
Antimicrobial agents are fed at subtherapeutic levels to poultry to improve their growth rate and feed conversion, and at therapeutic levels to prevent bacterial infections. Polymixin B and combinations of (1) trimethoprim and sulfadiazine, (2) neomycin and polymixin, and (3) trimethoprim and polymixin B have been administered in feed or drinking water to reduce the levels of Salmonella in chickens (Craven, 1995). Williams (1985) reported that feeding oxytetracycline and/or neomycin reduced S. typhimurium levels in broiler intestines. On the other hand, feeding antibiotics such as avoparicin and lincomycin favored colonization of $S$. typhimurium while nitrofurazone enhanced colonization of S. infantis (Glisson, 1998). Spread of Salmonella to contact chickens was subsequently observed. The increase in Salmonella colonization could be the result of a decrease in total microbial count of the natural gut microflora. Administering these antibiotics can result in gradual emergence of antibiotic resistant Salmonella. One such human pathogen, S. tyhimurium DT 104, has been found to be resistant to several antibiotics such as ampicillin, chloramphenicol, sulfonamides, streptomycin, and tetracyline. Approval of drugs such as sarafloxacin in poultry may contribute to the emergence and circulation of fluoroquinolone (nalidixic acid and ciprofloxacin) resistant strains of Salmonella (Herikstad et al., 1997). Drug resistant strains of S. enteritidis PT 4 and $S$. typhimurium DT 104 have been implicated in several outbreaks of salmonellosis. These drug resistant Salmonella strains, in turn, could contaminate poultry carcasses eventually leading to salmonellosis outbreaks among humans. It would be difficult to treat illnesses associated with such outbreaks with conventional antibiotics.

\section{Effect of litter pH and water activity}

Litter $\mathrm{pH}$ and Aw could play an important role in controlling or suppressing the growth of salmonellae in the environment within the production facilities. In F5, the average $\mathrm{pH}$ and 
Aw measured from the sampled pens at week 10 and 18 were 7.53 and 0.959 , and 7.62 and 0.958, respectively (Table 17). Litter $\mathrm{pH}$ and Aw measurement data were not available during week 2 of the sampling period. Although frequency of Salmonella detection increased from 17\% at week 2 to $50 \%$ at week 18 in litter samples (Table 6), there was no significant change in litter $\mathrm{pH}$ and Aw measurements from week 10 to 18.

In F6, the average $\mathrm{pH}$ and $\mathrm{Aw}$ at week 6, 12 and 21 were 6.59 and $0.974,7.48$ and 0.981 , and 8.10 and 0.870 , respectively (Table 18). Although Salmonella was not detected in litter samples at week 6, frequency of detection decreased from $50 \%$ at week 13 to $17 \%$ at week 21 (Table 7). A high litter $\mathrm{pH}(8.10)$ and low Aw (0.870) at week $21(\mathrm{p}<0.05)$ could have reduced presence of Salmonella in litter samples, when compared to week 6 and week 13 of the grow-out period. Opara et al. (1992) observed a negative correlation between Salmonella-positive, houserepresentative drag swab (HRDS) samples and litter $\mathrm{pH}$. They concluded that an increase in litter $\mathrm{pH}$ was associated with a decrease in Salmonella-positive, HRDS samples collected from 13 chicken houses. The authors also reported a positive correlation between HRDS samples and litter Aw indicating that Salmonella prevalence increased with increased litter moisture. A high litter $\mathrm{pH}$, as a result of ammonia, and low Aw suppress the growth of S. typhimurim, $S$. senftenberg, and S. thompson (Opara et al., 1992). These authors attributed the bactericidal activity to a lower Aw that is unfavorable to Salmonella viability and to a high litter $\mathrm{pH}$ from ammonia dissolved in the available moisture of the litter. A reduction of litter Aw and/or increased litter $\mathrm{pH}$ in the turkey grow-out facility may serve as an intervention measure in controlling Salmonella.

In F7, the average $\mathrm{pH}$ and Aw at week 0, 2, 10, 14, and 21 were 5.26 and 0.410, 6.55 and 0.967, 7.48 and 0.962, 6.96 and 0.979, and 7.70 and 0.953, respectively (Table 19). The low pH 
(5.26) and Aw (0.410) of fresh litter may be responsible for no Salmonella in litter samples at day 0 (Table 8). Absence of Salmonella in fresh litter can also be attributed to heat processing during drying and processing. However, when poults were assigned to pens, litter $\mathrm{pH}$ reached neutrality (6.55-7.70) and a Aw above 0.95 during the grow-out period. These conditions were conducive for harboring salmonellae. Salmonella has been reported to proliferate from $\mathrm{pH} 4.5$ to 9.5, with an optimum pH for growth of 6.5 to 7.5 (D'Aoust, 1997). Water activity below 0.94 and above 0.4 are detrimental to Salmonella survival (Turnbull and Snoeyenbos, 1973). However, Salmonella was not detected in any of the litter samples during the grow-out period (Table 8), indicating that factors other than litter $\mathrm{pH}$ and $\mathrm{Aw}$ could be responsible for a $0 \%$ frequency of detection.

No relationship was observed between litter $\mathrm{pH}$ and Aw, and Salmonella detection in F8. Average $\mathrm{pH}$ and $\mathrm{Aw}$ at week 2, 15, and 20 were 6.34 and $0.983,7.81$ and 0.944 , and 7.11 and 0.956, respectively (Table 20). Salmonella was detected in $13 \%$ of litter samples at week 2, but was not detected at week 15 and 20 (Table 9).

\section{Effect of environmental conditions}

Maximum and minimum temperatures inside the turkey production facility (averaged across north and south sides; Fig. 1) and percent relative humidity for F6, F7, and F8 are illustrated in Figs. 2, 3 and 4, respectively. Data were not available for F5 due to a malfunctioning of the temperature sensor. In F6, maximum and minimum temperatures inside the facility decreased with the grow-out period. While broad fluctuations were observed in relative humidity, the differences between maximum and minimum temperature measurements were uniform (Fig. 2). No relationship was observed between temperature differences and prevalence of Salmonella throughout the grow-out period in F6 because no significant changes 
were observed in Salmonella frequency (Table 7). In F7, differences between maximum and minimum temperatures were greater from approximately 42 days until the end of the production period (Fig. 3). Relative humidity fluctuations were observed from day 0 to day 40. Large differences between the maximum and minimum temperatures would stress turkeys, inducing them to shed and transmit Salmonella within the facility. Salmonella remained undetected in sources sampled in F7 during the grow-out period, thus there was no relationship between temperature fluctuation and prevalence of Salmonella. In F8, the difference between maximum and minimum temperatures was greater after approximately 70 days of the grow-out period (Fig. 4). Similar to F7, no relationship was observed between temperature differences and prevalence of Salmonella in F8 because no significant changes were observed in Salmonella frequency (Table 9). No relationship between temperature and prevalence of Salmonella in F7 and F8 may have been due to addition of Terminate ${ }^{\mathrm{TM}}$ to the feed. The effectiveness of this feed additive in reducing the frequency of Salmonella detection was greater than stress-induced shedding and/or proliferation of Salmonella caused by temperature fluctuations.

Because the flocks were reared at different times during the year, effect of seasonal changes was evaluated. Flock 6 was sampled from September 1997 to February 1998 (winter), F7 was sampled from March 1998 to August 1998 (summer), and F8 was sampled from January 1999 to June 1999 (spring) (Table 1). Temperature differences were greater during summer months than winter and spring months. Seasonal changes did not affect frequency of Salmonella detection in this study. Hoover and coworkers (1997) found that greater temperature fluctuation during summer months contributed to greater Salmonella shedding from turkeys. McBride and coworkers (1978) found that Salmonella infection among broiler flocks entering the slaughter facility during the summer were not different from flocks arriving in winter. Temperature 
differences can have a profound effect on Salmonella colonization dynamics (Soerjadi et al., 1979). High environmental temperatures have been reported to depress the immune system in young chickens (Thaxton and Siegel, 1970).

\section{Sex effect}

Male and female turkeys were placed only in F5 and F8 of the BUTA production trials. A total of 42 samples from turkey ceca, litter, and drinkers were positive for Salmonella in F5. Of these 42 samples, Salmonella was detected more frequently in male (57\%) than in female $(43 \%)$ turkeys. In litter and drinker samples, frequency of Salmonella detection was higher in males than in females (Fig. 5). A frequency of Salmonella detection among male turkeys could be the result of greater sensitivity of male birds to stimuli such as presence of personnel working in the production facility. This stimulus, in turn, could contribute to stress. Male turkeys appeared more active than females. This stress may cause greater shedding of Salmonella in their feces, which might cross contaminate litter and drinkers within each pen. Observations regarding the mobility of turkeys were in context with this particular flock, and they do not represent mobility of birds in a typical grow-out facility. In a study conducted by McBride and coworkers (1978) on 25 turkey flocks, the average incidence of salmonellae in male and female turkeys was 7.4 (0 to $36 \%$ ) and $9.2 \%$ (0 to $44 \%$ ), respectively. With respect to turkeys in F8, Salmonella was detected in $75 \%$ males and $25 \%$ females. One Salmonella-positive sample each of litter, drinker, and feeder content was isolated from male pens, while the remaining sample was isolated from the ceca of a female turkey.

\section{CONCLUSIONS}

Contamination of poultry products with Salmonella concerns consumers and the poultry industry. Reduction of Salmonella is necessary on farms where turkeys are bred, hatched, 
brooded, and raised. This study was undertaken to identify and confirm the key sources responsible for Salmonella colonization at a turkey production facility. Frequency of Salmonella detection varied from 0 to $21 \%$ across the four flocks sampled. Turkeys were the major sources and litter and drinkers were the major vectors of Salmonella contamination in the turkey production facility. Salmonella colonizes the gastrointestinal tract of poultry and, through horizontal transmission, contaminates other birds and eventually carcasses. A knowledge of preharvest factors responsible for Salmonella colonization would help integrators and poultry producers design hazard analysis and critical control point (HACCP) protocols to safeguard fresh turkey against Salmonella contamination during processing.

Salmonella heidelberg was the most prevalent serotype isolated among the sampled flocks. About $25 \%$ of Salmonella serotypes were resistant to one or more antibiotics tested. Some serotypes appeared flock specific and were associated with specific preharvest sources. Serotype information and antibiogram patterns can be used, in part, to delineate possible transmission pathways of Salmonella in the rearing facilities. A transmission pathway could not be completely established in the present study due to limitation on the number of samples collected and number of isolates serotyped and screened for their antibiotic resistance pattern. Genotypic methods of differentiating Salmonella serotypes can provide a complete picture on the transmission pathway. This information could be used to define critical, preharvest control points on the farm. Intervention at these points would reduce and/or eliminate horizontal transmission and Salmonella-positive birds arriving at the processing plants. Although antibiotics have improved growth efficiency and reduced bacterial infections in poultry, widespread use could result in emergence of antibiotic resistant strains in farm birds and fresh and processed poultry products. 
Environmental conditions, farm management, and husbandry practices within the poultry facility could contribute to stressful conditions increasing the potential for Salmonella colonization. No relationship was observed between environmental conditions and Salmonella prevalence in this study. Salmonella was detected more frequently in male than in female turkeys. A higher frequency of Salmonella in male turkeys warrants consideration in designing protocols that reduce Salmonella colonization by minimizing stress in rearing male turkeys.

Salmonella is a management disease, and its control depends on controlling the sources of contamination and transmission. To reduce and/or eliminate the incidence of Salmonella in turkeys before they enter the processing plants, a concerted effort among hatchery management, breeders, producers, integrators, and feed manufacturers is necessary. 


\section{REFERENCES}

Al-Dagal, M. and Fung, D.Y.C. 1993. Aeromicrobiology: An assessment of a new meat research complex. J. Environ. Health 56:7-14.

Amick, Morris, J. and Kenney, P. B. 1997. Characterization of insects' contribution to the incidence of Salmonella in turkey flocks. $86^{\text {th }}$ Poultry Sci. Annual Meeting 76(Supplement $1): 14$.

Amick-Morris, J. 1998. Insects' contribution to Salmonella transmission in turkey flocks. M.S. Thesis. West Virginia University, Morgantown.

American Veterinary Medical Association. 1993. Report of the AVMA panel on euthanasia. J. Am. Vet. Med. Assoc. 202:229-249.

Bailey, J. S. 1988. Integrated colonization control of Salmonella in poultry. Poultry Sci. 67:928-932.

Bailey, J. S. 1993. Control of Salmonella and Campylobacter in poultry production. A summary of work at Russell Research Center. Poultry Sci. 72:1169-1173.

Bailey, J.S. and Cox, N.A. 1992. Universal preenrichment broth for the simultaneous detection of Salmonella and Listeria in foods. J. Food Prot. 55:256-259.

Bains, B.S. and MacKenzie, M.A. 1974. Transmission of Salmonella through a integrated poultry organisation. Poultry Sci. 53:1114-1118.

Barnes, E.M., Mead, G.C., Barnum, D.A. and Harry, E.G. 1972. The intestinal flora of the chicken in the period 2 to 6 weeks of age with particular reference to the anaerobic bacteria. Brit. Poultry Sci. 13:311-326.

Bhargava, K.K., O’Neil, J.B., Prior, M.G. and Dunkelgod, K.E. 1983. Incidence of Salmonella contamination in broiler chickens in Saskatchewan. Can. J. Comp Med. 47:27-32.

Bhatia, T.R.S. and McNabb, G.D. 1980. Dissemination of Salmonella in broiler-chicken operations. Avian Dis. 24:616-624.

Buzby, J. C., Roberts, T., Jordan Lin, C. -T. and MacDonald, J. M. 1996. Bacterial food borne diseases: Medical costs and productivity losses. Agric. Eco. Report 741:1-93

Carraminana, J. J., Yanguela, J., Blanco, D., Rota, C., Agustin, A. I., Arino, A. and Herrara, A. 1997. Salmonella incidence and distribution serotypes throughout processing in a Spanish poultry slaughterhouse. J. Food Prot. 60:1312-1317.

Cason, J.A., Cox, N.A. and Bailey, J.S. 1994. Transmission of Salmonella typhimurium during hatching of broiler chicks. Avian Dis. 38:583-588. 
Cox, N.A. 1998. Incidence and impact of salmonellae in broiler hatcheries. Proc. Intl. Symp. on Food-borne Salmonella in Poultry. pp. 88-92. Baltimore, MD.

Cox, N.A., Bailey, J.S., Thomson, J.E. and Juven, B.J. 1983. Salmonella and other Enteriobacteriaceae found in commercial poultry feed. Poultry Sci. 62:2169-2175.

Craven, S.E. 1995. Salmonella typhimurium, hydrophobic antibiotics and the intestinal colonization of broiler chicks. J. Appl. Poultry Res. 4:333-340.

D’Aoust, J-Y. 1997. Salmonella species. In Food Microbiology: Fundamentals and Frontiers (Eds.) M.P. Doyle, L.R. Beuchat and T.J. Montville pp 129-158. ASM Press, Washington, D.C.

Dougherty, T.J. 1976. A study of Salmonella contamination in broiler flocks. Poultry Sci. 55:1811-1815.

Glisson, J.R. 1998. Use of antibiotics to control Salmonella in poultry. Proc. Intl. Symp. on Food-borne Salmonella in Poultry. pp. 173-175. Baltimore, MD.

Goren, E., Dejong, W.A., Doormenbal, P., Koopman, J.P. and Kennis, H.M. 1988. Reduction of Salmonella infection of broilers by spray application of intestinal microflora: a longitudinal study. Vet. Q. 10:249-255.

Guo, L., Kenney, P. B. and Amick-Morris, J. D. 1997. Biofingerprinting Salmonella isolates from a turkey production environment with arbitrarily primed PCR. $86^{\text {th }}$ Poultry Sci. Annual Meeting 76(Supplement 1):15.

Herikstad, H., Hayes, P., Mokhatar, M., Fracaro, M.L., Threlfall, E.J. and Angulo, F.J. 1997. Emerging quinolone-resistant Salmonella in the United States. Emerg. Infect. Dis. 3:371-372.

Hoover, N. J., Kenney, P. B., Amick, J. D. and Hypes, W. A. 1997. Preharvest sources of Salmonella colonization in turkey production. Poultry Sci. 76:1232-1238.

Jones, F. T., Axtell, R. C., Rives, D. V., Scheideler, S. E., Tarvar, Jr. F. R., Walker, R. L. and Wineland, M. J. 1991. A survey of Salmonella contamination in modern broiler production. J. Food Prot. 54:502-507.

Kumar, M.C., York, M.D., McDowell, J.R. and Pomeroy, B.S. 1971. Dynamics of Salmonella infection in fryer roaster turkeys. Avian Dis. 15:221-232.

Lahellec, C. and Colin, P. 1985. Relationship between serotypes of Salmonellae from hatcheries and rearing farms and those from processed poultry carcasses. Brit. Poultry Sci. 26:179-186.

MacKenzie, M.A. and Bains, B.S. 1976. Dissemination of Salmonella serotypes from raw feed ingredients to chicken carcasses. Poultry Sci. 55:957-960. 
Mayes, F.J. and Takeballi, M.A. 1983. Microbial contamination of the hen's egg: a review. J. Food Protect. 46:1092-1098.

McBride, G.B., Brown, B. and Skura, B.J. 1978. Effect of bird type, growers, and season on the incidence of salmonellae in turkeys. J. Food Sci. 43:323-326.

McIlroy, S.G. 1998. Control of Salmonella contamination of poultry feeds. Proc. Intl. Symp. on Food-borne Salmonella in Poultry. pp. 83-87. Baltimore, MD.

McNamara, A. M. and Levine, P. 1998. Contamination of raw foods of avian origin. Proc. Intl. Symp. on Food-borne Salmonella in Poultry. pp. 56-69. Baltimore, MD.

Morgan-Jones, S.C. 1980. The occurrence of salmonellae during the rearing of broiler birds. Brit. Poultry Sci. 21:463-470.

Morgan-Jones, S.C. 1982. The presence of salmonellae during the rearing of turkeys. Brit. Poultry Sci. 23:481-486.

Morris, G.K., McMurray, B.L., Galton, M.M. and Wells, J.G. 1969. A study of the dissemination of salmonellosis in a commercial broiler chicken operation. Am. J. Vet. Res. 30:1413-1421.

Olsen, J. E., Brown, D. J., Skov, M. N. and Christensen, J. P. 1993. Bacterial typing methods suitable for epidemiological analysis. Application in investigations of salmonellosis among livestock. Vet. Q. 15:125-135.

Opara, O.O., Carr, L.E., Russek-Cohen, E., Tate C.R., Mallinson, E.T., Miller, R.G., Stewart, L.E., Johnston, R.W. and Joseph, S.W. 1992. Correlation of water activity and other environmental conditions with repeated detection of Salmonella contamination on poultry farms.

Opitz, H. M., El-Begearmi, M., Flegg, P. and Beane, D. 1993. Effectiveness of five feed additives in chicks infected with Salmonella enteritidis phage type 13A. J. Appl. Poultry Res. 2:147-153.

Simmons, G.C. and Byrnes, R.V. 1972. The origin of Salmonella in chickens and chicken carcases. Aust. Vet. J. 48:186-189.

Snoeyenbos, G.W., Carbon, V.L., McKie, B.A. and Singer, C.F. 1974. An epidemiological study of salmonellosis in chickens. Avian Dis. 18:653-667.

Soerjadi, A.S., Druitt, J.H., Lloyd, A.B. and Cumming, R.B. 1979. Effect of environmental temperature on susceptibility of young chickens to Salmonella typhimurium. Aust. Vet. J. 55:413-417.

Thaxton, J.P. and Siegel, H.S. 1970. Immunodepression in young chickens by high environmental temperature. Poultry Sci. 49:202-205. 
Threlfall, E. J., Powell, N.G. and Rowe, B. 1994. Differentiation of salmonellas by molecular methods. PHLS Microbiol. Dig. 11:199-202.

Turnbull, P.C.B. and Snoeyenbos, G.H. 1973. The roles of ammonia, water activity, and pH in the salmonellacidal effect of long-used poultry litter. Avian Dis. 17:72-86.

Williams, B.J. 1985. The effect of neomycin and oxytetracycline alone or combined upon the incidence of salmonellosis in broiler chickens. Poultry Sci. 64:1455-1457. 
Table 1. Characteristics of turkey flocks sampled during the survey.

\begin{tabular}{|c|c|c|c|c|c|c|c|}
\hline $\begin{array}{l}\text { Turkey } \\
\text { flocks }\end{array}$ & $\begin{array}{l}\text { BUTA production } \\
\text { trials }\end{array}$ & $\begin{array}{l}\text { Sampling } \\
\text { period }\end{array}$ & $\begin{array}{l}\text { Sampling } \\
\text { frequency } \\
\text { (weeks) }\end{array}$ & $\begin{array}{c}\text { Number of } \\
\text { pens sampled }\end{array}$ & Sex of birds & Samples $^{1}$ & $\begin{array}{l}\text { Environmental } \\
\text { characteristics }\end{array}$ \\
\hline Flock 5 & $\begin{array}{l}6 \text { strains x } 2 \\
\text { genders }\end{array}$ & $\begin{array}{l}\text { April } 1997 \text { to } \\
\text { August } 1997\end{array}$ & 2,10, and 18 & 12 & $\begin{array}{l}\text { Males and } \\
\text { females }\end{array}$ & $\begin{array}{l}\mathrm{CC}, \mathrm{L}, \mathrm{D}, \mathrm{ES} \text {, } \\
\mathrm{A} \text {, and } \mathrm{F}\end{array}$ & $\begin{array}{l}\text { Litter } \mathrm{pH} \text { and } \\
\text { Aw }\end{array}$ \\
\hline Flock 6 & 3 strains $\times 2$ feeds & $\begin{array}{l}\text { September } \\
1997 \text { to } \\
\text { February } 1998\end{array}$ & 6,13, and 21 & 6 & Males & $\begin{array}{l}\mathrm{CC}, \mathrm{L}, \mathrm{D}, \mathrm{ES}, \\
\mathrm{A}, \mathrm{F}, \text { and } \mathrm{FC}\end{array}$ & $\begin{array}{l}\text { Litter } \mathrm{pH} \text { and } \\
\text { Aw, and } \\
\text { temperature } \\
\text { and relative } \\
\text { humidity }^{2}\end{array}$ \\
\hline Flock 7 & 4 strains $\times 2$ feeds & $\begin{array}{l}\text { March } 1998 \text { to } \\
\text { August } 1998\end{array}$ & $\begin{array}{l}0,2,10,14, \\
\text { and } 21\end{array}$ & $5-10$ & Females & $\begin{array}{l}\text { IY, CC, CrC, } \\
\mathrm{L}, \mathrm{D}, \mathrm{ES}, \mathrm{A}, \\
\mathrm{F}, \mathrm{FC} \text {, and } \\
\text { BL }\end{array}$ & $\begin{array}{l}\text { Litter } \mathrm{pH} \text { and } \\
\text { Aw, and } \\
\text { temperature } \\
\text { and relative } \\
\text { humidity }\end{array}$ \\
\hline Flock 8 & $\begin{array}{l}4 \text { strains x } 2 \\
\text { genders }\end{array}$ & $\begin{array}{l}\text { January } 1999 \\
\text { to June } 1999\end{array}$ & 2,15 , and 20 & $6-8$ & $\begin{array}{l}\text { Males and } \\
\text { Females }\end{array}$ & $\begin{array}{l}\mathrm{CC}, \mathrm{CrC}, \mathrm{L}, \\
\mathrm{D}, \mathrm{ES}, \mathrm{A}, \mathrm{F}, \\
\text { and } \mathrm{FC}\end{array}$ & $\begin{array}{l}\text { Litter } \mathrm{pH} \text { and } \\
\text { Aw, and } \\
\text { temperature } \\
\text { and relative } \\
\text { humidity }\end{array}$ \\
\hline
\end{tabular}

\footnotetext{
${ }^{1} \mathrm{IY}=$ intestine and yolk sac samples; $\mathrm{CC}=$ turkey cecal contents; $\mathrm{CrC}=$ turkey crop contents; $\mathrm{L}=$ litter samples; $\mathrm{D}=$ drinker samples; ES = environmental swabs; $\mathrm{A}=$ air samples; $\mathrm{F}=$ feed samples; $\mathrm{FC}=$ feeder contents; $\mathrm{BL}=$ box liner samples

${ }^{2}$ Maximum and minimum temperatures and relative humidity were measured inside the production facility.
} 
Table 2. Pen assignments for the sampled flocks.

\begin{tabular}{|c|c|c|c|c|c|c|c|c|}
\hline \multirow[t]{2}{*}{ Pen No. } & \multicolumn{2}{|c|}{ Flock 5} & \multicolumn{2}{|c|}{ Flock 6} & \multicolumn{2}{|c|}{ Flock 7} & \multicolumn{2}{|c|}{ Flock 8} \\
\hline & Strain & Sex & Strain & Feed & Strain & Feed & Strain & Sex \\
\hline 1 & $78 \times 12$ & Toms & Hybrid & $\mathrm{USA}^{1}$ & Nicholas & $\mathrm{LC}^{3}$ & Nicholas & Toms \\
\hline 2 & $72 \times 71$ & Toms & Big 6 & $\mathrm{EHP}^{2}$ & Hybrid & $\mathrm{HH}^{4}$ & 37-Roaster & Toms \\
\hline 3 & $78 \times 25$ & Toms & Nicholas & EHP & Line 37 & $\mathrm{HH}$ & Big 6 & Toms \\
\hline 4 & $38 \times 71$ & Toms & Big 6 & USA & Big 6 & LC & Nicholas & Toms \\
\hline 5 & $72 \times 12$ & Toms & Hybrid & EHP & Nicholas & $\mathrm{HH}$ & 37-Roaster & Toms \\
\hline 6 & $72 \times 25$ & Toms & Nicholas & USA & Hybrid & LC & Hybrid & Toms \\
\hline 7 & $72 \times 17$ & Toms & Nicholas & EHP & Hybrid & $\mathrm{HH}$ & Big 6 & Toms \\
\hline 8 & $38 \times 71$ & Toms & Hybrid & USA & Big 6 & $\mathrm{LC}$ & Nicholas & Toms \\
\hline 9 & $72 \times 71$ & Toms & Big 6 & EHP & Hybrid & LC & 37-Roaster & Toms \\
\hline 10 & $72 \times 25$ & Toms & Hybrid & EHP & Nicholas & $\mathrm{HH}$ & Hybrid & Toms \\
\hline 11 & $78 \times 12$ & Toms & Nicholas & USA & Line 37 & $\mathrm{LC}$ & Big 6 & Toms \\
\hline 12 & $78 \times 25$ & Toms & Big 6 & USA & Big 6 & $\mathrm{HH}$ & Hybrid & Toms \\
\hline 13 & $72 \times 71$ & Hens & Nicholas & USA & Line 37 & LC & Nicholas & Hens \\
\hline 14 & $78 \times 25$ & Hens & Big 6 & USA & Big 6 & $\mathrm{HH}$ & 37-Roaster & Hens \\
\hline 15 & $72 \times 25$ & Hens & Hybrid & EHP & Hybrid & $\mathrm{HH}$ & Hybrid & Hens \\
\hline 16 & $72 \times 12$ & Hens & Nicholas & EHP & Nicholas & LC & Nicholas & Hens \\
\hline 17 & $38 \times 71$ & Hens & Big 6 & EHP & Line 37 & $\mathrm{HH}$ & 37-Roaster & Hens \\
\hline 18 & $78 \times 12$ & Hens & Hybrid & USA & Big 6 & $\mathrm{LC}$ & Big 6 & Hens \\
\hline 19 & $72 \times 25$ & Hens & Big 6 & EHP & Nicholas & $\mathrm{HH}$ & Hybrid & Hens \\
\hline 20 & $72 \times 71$ & Hens & Nicholas & USA & Line 37 & LC & Nicholas & Hens \\
\hline 21 & $38 \times 71$ & Hens & Hybrid & EHP & Nicholas & LC & Big 6 & Hens \\
\hline 22 & $78 \times 12$ & Hens & Big 6 & USA & Hybrid & $\mathrm{LC}$ & 37-Roaster & Hens \\
\hline 23 & $78 \times 25$ & Hens & Hybrid & USA & Big 6 & $\mathrm{HH}$ & Big 6 & Hens \\
\hline 24 & $72 \times 12$ & Hens & Nicholas & EHP & Line 37 & $\mathrm{HH}$ & Hybrid & Hens \\
\hline
\end{tabular}

Shaded areas indicate brooding pens; ${ }^{1}$ BUTA-USA; ${ }^{2}$ European high protein; ${ }^{3}$ Least cost; ${ }^{4}$ Heavy hen 
Table 3. Dietary specifications of the British United Turkeys of America feeding program used for flock 6.

\begin{tabular}{|c|c|c|c|c|c|c|c|c|c|c|c|c|c|}
\hline \multirow{2}{*}{$\begin{array}{l}\text { Diet } \\
\text { composition }\end{array}$} & \multicolumn{7}{|c|}{ BUTA (USA) Feeding Program } & \multicolumn{6}{|c|}{ European High Protein (EHP) Feeding Program } \\
\hline & $\begin{array}{l}\text { Starter } \\
\text { I }\end{array}$ & $\begin{array}{l}\text { Starter } \\
\text { II }\end{array}$ & $\begin{array}{c}\text { Grower } \\
\text { I }\end{array}$ & $\begin{array}{l}\text { Grower } \\
\text { II }\end{array}$ & $\begin{array}{c}\text { Grower } \\
\text { III }\end{array}$ & Finish I & $\begin{array}{l}\text { Finish } \\
\text { II }\end{array}$ & $\begin{array}{l}\text { Starter } \\
\text { I }\end{array}$ & $\begin{array}{l}\text { Starter } \\
\text { II }\end{array}$ & $\begin{array}{c}\text { Grower } \\
\text { I }\end{array}$ & $\begin{array}{l}\text { Grower } \\
\text { II }\end{array}$ & Finish I & $\begin{array}{l}\text { Finish } \\
\text { II }\end{array}$ \\
\hline ME & 1290 & 1310 & 1350 & 1425 & 1475 & 1525 & 1550 & 1275 & 1340 & 1425 & 1475 & 1540 & 1550 \\
\hline Protein & 28.5 & 26.0 & 24.0 & 22.0 & 20.0 & 18.0 & 17.0 & 31.50 & 27.70 & 24.83 & 21.03 & 18.71 & 17.22 \\
\hline Lysine & 1.80 & 1.65 & 1.48 & 1.30 & 1.12 & 1.00 & 0.90 & 1.88 & 1.66 & 1.45 & 1.21 & 1.07 & 0.92 \\
\hline TSAA & 1.15 & 1.10 & 1.02 & 0.95 & 0.90 & 0.80 & 0.75 & 1.22 & 1.17 & 1.10 & 0.97 & 0.91 & 0.81 \\
\hline Methionine & 0.70 & 0.65 & 0.60 & 0.56 & 0.51 & 0.48 & 0.42 & 0.68 & 0.66 & 0.61 & 0.54 & 0.51 & 0.45 \\
\hline Arginine & 1.96 & 1.78 & 1.58 & 1.43 & 1.21 & 1.10 & 1.00 & 2.03 & 1.81 & 1.60 & 1.39 & 1.25 & 1.14 \\
\hline Threonine & 1.05 & 1.00 & 0.94 & 0.84 & 0.70 & 0.64 & 0.59 & 1.20 & 1.07 & 0.99 & 0.79 & 0.68 & 0.60 \\
\hline Calcium & 1.50 & 1.40 & 1.30 & 1.20 & 1.10 & 1.00 & 0.90 & 1.50 & 1.30 & 1.20 & 1.10 & 1.00 & 0.90 \\
\hline A. Phos. & 0.75 & 0.70 & 0.65 & 0.60 & 0.55 & 0.50 & 0.45 & 0.75 & 0.65 & 0.60 & 0.55 & 0.50 & 0.45 \\
\hline Sodium & $\begin{array}{c}0.16- \\
0.19\end{array}$ & $\begin{array}{c}0.16- \\
0.19\end{array}$ & $\begin{array}{c}0.16- \\
0.19\end{array}$ & $\begin{array}{c}0.16- \\
0.19\end{array}$ & $\begin{array}{c}0.16- \\
0.19\end{array}$ & $\begin{array}{c}0.16- \\
0.19\end{array}$ & $\begin{array}{c}0.16- \\
0.19\end{array}$ & $\begin{array}{c}0.16- \\
0.18\end{array}$ & $\begin{array}{c}0.16- \\
0.19\end{array}$ & $\begin{array}{c}0.16- \\
0.19\end{array}$ & $\begin{array}{c}0.16- \\
0.19\end{array}$ & $\begin{array}{c}0.16- \\
0.19\end{array}$ & $\begin{array}{c}0.16- \\
0.19\end{array}$ \\
\hline Chloride & $\begin{array}{c}0.20- \\
0.25\end{array}$ & $\begin{array}{c}0.20- \\
0.25\end{array}$ & $\begin{array}{l}0.20- \\
0.25\end{array}$ & $\begin{array}{c}0.20- \\
0.25\end{array}$ & $\begin{array}{c}0.20- \\
0.25\end{array}$ & $\begin{array}{c}0.20- \\
0.25\end{array}$ & $\begin{array}{c}0.20- \\
0.25\end{array}$ & $\begin{array}{c}0.20- \\
0.25\end{array}$ & $\begin{array}{c}0.20- \\
0.25\end{array}$ & $\begin{array}{l}0.20- \\
0.25\end{array}$ & $\begin{array}{c}0.20- \\
0.25\end{array}$ & $\begin{array}{c}0.20- \\
0.25\end{array}$ & $\begin{array}{c}0.20- \\
0.25\end{array}$ \\
\hline Pound/tom & 2.2 & 8.0 & 12.0 & 18.0 & 22.0 & 24.0 & Market & 3.5 & 12.0 & 22.0 & 30.0 & 40.0 & Market \\
\hline
\end{tabular}


Table 4. Dietary specifications of the British United Turkeys of America feeding program used for flock 7.

\begin{tabular}{|c|c|c|c|c|c|c|c|c|c|c|c|c|c|c|}
\hline \multirow{2}{*}{$\begin{array}{l}\text { Diet } \\
\text { composition }\end{array}$} & \multicolumn{7}{|c|}{ Heavy Hen $(\mathrm{HH})$ Feeding Program } & \multicolumn{7}{|c|}{ Least Cost (LC) Hen Feeding Program } \\
\hline & $\begin{array}{l}\text { Starter } \\
\text { I (201) }\end{array}$ & $\begin{array}{l}\text { Starter } \\
\text { II (202) }\end{array}$ & $\begin{array}{l}\text { Grower } \\
\text { I (203) }\end{array}$ & $\begin{array}{l}\text { Grower } \\
\text { II (204) }\end{array}$ & $\begin{array}{c}\text { Grower } \\
\text { III } \\
(205)\end{array}$ & $\begin{array}{c}\text { Finish I } \\
\text { (206) }\end{array}$ & $\begin{array}{l}\text { Finish } \\
\text { II (207) }\end{array}$ & $\begin{array}{l}\text { Starter } \\
\text { I (401) }\end{array}$ & $\begin{array}{l}\text { Starter } \\
\text { II (402) }\end{array}$ & $\begin{array}{l}\text { Grower } \\
\text { I (403) }\end{array}$ & $\begin{array}{l}\text { Grower } \\
\text { II (404) }\end{array}$ & $\begin{array}{c}\text { Grower } \\
\text { III } \\
(405)\end{array}$ & $\begin{array}{c}\text { Finish I } \\
\text { (406) }\end{array}$ & $\begin{array}{c}\text { Finish } \\
\text { II (407) }\end{array}$ \\
\hline $\mathrm{ME}$ & 1290 & 1325 & 1375 & 1450 & 1475 & 1500 & 1550 & 1290 & 1325 & 1400 & 1450 & 1500 & 1525 & 1550 \\
\hline Protein & 28.5 & 26.0 & 24.0 & 22.0 & 19.3 & 18.2 & 16.2 & 28.5 & 26.0 & 24.0 & 22.3 & 19.3 & 17.5 & 15.4 \\
\hline Lysine & 1.78 & 1.62 & 1.45 & 1.30 & 1.15 & 1.02 & 0.93 & 1.78 & 1.62 & 1.55 & 1.35 & 1.15 & 0.98 & 0.88 \\
\hline TSAA & 1.20 & 1.15 & 1.05 & 0.95 & 0.88 & 0.82 & 0.75 & 1.20 & 1.15 & 1.08 & 0.95 & 0.85 & 0.75 & 0.68 \\
\hline Arginine & 1.96 & 1.80 & 1.58 & 1.43 & 1.21 & 1.10 & 1.00 & 1.96 & 1.76 & 1.58 & 1.47 & 1.25 & 1.10 & 0.95 \\
\hline Threonine & 1.05 & 1.00 & 0.94 & 0.84 & 0.74 & 0.67 & 0.59 & 1.05 & 1.00 & 0.95 & 0.84 & 0.72 & 0.65 & 0.55 \\
\hline Calcium & 1.40 & 1.30 & 1.20 & 1.15 & 1.10 & 1.00 & 0.90 & 1.40 & 1.30 & 1.20 & 1.15 & 1.05 & 1.00 & 0.90 \\
\hline A. Phos. & 0.75 & 0.70 & 0.63 & 0.60 & 0.55 & 0.50 & 0.45 & 0.75 & 0.65 & 0.63 & 0.60 & 0.55 & 0.50 & 0.45 \\
\hline Sodium & $\begin{array}{c}0.16- \\
0.18\end{array}$ & $\begin{array}{c}0.16- \\
0.18\end{array}$ & $\begin{array}{c}0.16- \\
0.18\end{array}$ & $\begin{array}{c}0.16- \\
0.18\end{array}$ & $\begin{array}{c}0.16- \\
0.18\end{array}$ & $\begin{array}{c}0.16- \\
0.18\end{array}$ & $\begin{array}{c}0.16- \\
0.18\end{array}$ & $\begin{array}{c}0.16- \\
0.18\end{array}$ & $\begin{array}{c}0.16- \\
0.18\end{array}$ & $\begin{array}{c}0.16- \\
0.18\end{array}$ & $\begin{array}{c}0.16- \\
0.18\end{array}$ & $\begin{array}{c}0.16- \\
0.18\end{array}$ & $\begin{array}{c}0.16- \\
0.18\end{array}$ & $\begin{array}{c}0.16- \\
0.18\end{array}$ \\
\hline Chloride & $\begin{array}{c}0.20- \\
0.25\end{array}$ & $\begin{array}{l}0.20- \\
0.25\end{array}$ & $\begin{array}{l}0.20- \\
0.25\end{array}$ & $\begin{array}{l}0.20- \\
0.25\end{array}$ & $\begin{array}{l}0.20- \\
0.25\end{array}$ & $\begin{array}{l}0.20- \\
0.25\end{array}$ & $\begin{array}{c}0.20- \\
0.25\end{array}$ & $\begin{array}{c}0.20- \\
0.25\end{array}$ & $\begin{array}{l}0.20- \\
0.25\end{array}$ & $\begin{array}{l}0.20- \\
0.25\end{array}$ & $\begin{array}{l}0.20- \\
0.25\end{array}$ & $\begin{array}{l}0.20- \\
0.25\end{array}$ & $\begin{array}{l}0.20- \\
0.25\end{array}$ & $\begin{array}{l}0.20- \\
0.25\end{array}$ \\
\hline Age (days) & $0-21$ & $22-42$ & $43-63$ & $64-77$ & $78-98$ & $\begin{array}{l}99- \\
112\end{array}$ & $\begin{array}{c}\text { Mark } \\
\text { et }\end{array}$ & $0-14$ & $15-28$ & $29-49$ & $50-63$ & $64-77$ & $78-91$ & $\begin{array}{c}\text { Mark } \\
\text { et }\end{array}$ \\
\hline Pound/hen & 2.00 & 5.62 & 9.75 & 8.50 & 15.14 & 11.50 & 25.50 & 1.00 & 2.50 & 6.93 & 6.96 & 8.50 & 9.79 & 42.45 \\
\hline Total lbs & 1350 & 4720 & 8200 & 7150 & 12100 & 9200 & 19400 & 675 & 2100 & 5800 & 5800 & 7200 & 7800 & 32000 \\
\hline
\end{tabular}


Table 5. Dietary specifications of the British United Turkeys of America feeding program used for flock 8 .

\begin{tabular}{lccccccc}
\hline Diet & \multicolumn{7}{c}{ Heavy Bird Feeding Program } \\
$\begin{array}{lccccc}\text { Composition } \\
\end{array}$ & $\begin{array}{c}\text { Starter } \\
\text { I }\end{array}$ & $\begin{array}{c}\text { Starter } \\
\text { II }\end{array}$ & $\begin{array}{c}\text { Grower } \\
\text { I }\end{array}$ & $\begin{array}{c}\text { Grower } \\
\text { II }\end{array}$ & $\begin{array}{c}\text { Grower } \\
\text { III }\end{array}$ & $\begin{array}{c}\text { Finisher } \\
\text { I }\end{array}$ & $\begin{array}{c}\text { Finisher } \\
\text { II }\end{array}$ \\
\hline ME & 1290 & 1325 & 1375 & 1450 & 1475 & 1500 & 1550 \\
Protein & 28.5 & 26.0 & 24.0 & 22.0 & 19.3 & 18.2 & 16.2 \\
Lysine & 1.78 & 1.62 & 1.45 & 1.30 & 1.15 & 1.02 & 0.93 \\
TSAA & 1.20 & 1.15 & 1.05 & 0.95 & 0.88 & 0.82 & 0.75 \\
Arginine & 1.96 & 1.80 & 1.58 & 1.43 & 1.21 & 1.10 & 1.00 \\
Threonine & 1.05 & 1.00 & 0.94 & 0.84 & 0.74 & 0.67 & 0.59 \\
Calcium & 1.40 & 1.30 & 1.20 & 1.15 & 1.10 & 1.00 & 0.90 \\
A. Phos. & 0.75 & 0.70 & 0.63 & 0.60 & 0.55 & 0.50 & 0.45 \\
Sodium & $0.16-$ & $0.16-$ & $0.16-$ & $0.16-$ & $0.16-$ & $0.16-$ & $0.16-$ \\
& 0.18 & 0.18 & 0.18 & 0.18 & 0.18 & 0.18 & 0.18 \\
Chloride & $0.20-$ & $0.20-$ & $0.20-$ & $0.20-$ & $0.20-$ & $0.20-$ & $0.20-$ \\
& 0.25 & 0.25 & 0.25 & 0.25 & 0.25 & 0.25 & 0.25 \\
& & & & & & & \\
\hline Age (days) & $0-21$ & $22-42$ & $43-63$ & $64-77$ & $78-98$ & $99-112$ & Market \\
& & & & & & & \\
Pounds/hen & 2.00 & 5.62 & 9.75 & 8.50 & 15.14 & 11.50 & 25.50 \\
& & & & & & & \\
Age (days) & $0-21$ & $22-42$ & $43-63$ & $64-84$ & $85-105$ & $106-126$ & Market \\
& & & & & & & \\
Pounds/tom & 2.00 & 7.85 & 11.84 & 17.56 & 21.00 & 23.55 & 15.00 \\
\hline \hline
\end{tabular}


Table 6. Frequency of Salmonella detected from various flock 5 samples in the turkey production facility.

\begin{tabular}{|c|c|c|c|c|c|}
\hline \multirow[t]{2}{*}{ Sample } & \multicolumn{3}{|c|}{$\begin{array}{c}\text { Grow-out Period } \\
\text { (number positive/number sampled) }\end{array}$} & \multirow{2}{*}{\multicolumn{2}{|c|}{ Total }} \\
\hline & Week 2 & Week 10 & Week 18 & & \\
\hline Turkey ceca & $6 / 24$ & $1 / 24$ & $15 / 24$ & $22 / 72$ & $(31 \%)^{1}$ \\
\hline Litter & $2 / 12$ & $1 / 12$ & $6 / 12$ & $9 / 36$ & $(25 \%)$ \\
\hline Drinkers & $2 / 12$ & $2 / 12$ & $6 / 12$ & $10 / 36$ & $(28 \%)$ \\
\hline $\begin{array}{l}\text { Environmental } \\
\text { swabs }\end{array}$ & $1 / 14$ & $0 / 18$ & $4 / 10$ & $5 / 42$ & $(12 \%)$ \\
\hline Air & $0 / 11$ & $0 / 10$ & $0 / 5$ & $0 / 26$ & \\
\hline Feed & $0 / 0$ & $0 / 3$ & $0 / 3$ & $0 / 6$ & \\
\hline Total & $\begin{array}{l}11 / 73 \\
(15 \%)\end{array}$ & $\begin{array}{l}4 / 79 \\
(5 \%)\end{array}$ & $\begin{array}{l}31 / 66 \\
(47 \%)\end{array}$ & $46 / 218$ & $(21 \%)$ \\
\hline
\end{tabular}

${ }^{1}$ Figures in parentheses indicate percent positive 
Table 7. Frequency of Salmonella detected from various flock 6 samples in the turkey production facility.

\begin{tabular}{|c|c|c|c|c|c|}
\hline \multirow[t]{2}{*}{ Sample } & \multicolumn{3}{|c|}{$\begin{array}{c}\text { Grow-out Period } \\
\text { (number positive/number sampled) }\end{array}$} & \multirow[t]{2}{*}{ Total } & \\
\hline & Week 6 & Week 13 & Week 21 & & \\
\hline Turkey ceca & $0 / 12$ & $0 / 12$ & $1 / 10$ & $1 / 34$ & $(3 \%)^{1}$ \\
\hline Litter & $0 / 6$ & $3 / 6$ & $1 / 6$ & $4 / 18$ & $(22 \%)$ \\
\hline Drinkers & $0 / 6$ & $0 / 6$ & $0 / 6$ & $0 / 18$ & \\
\hline $\begin{array}{l}\text { Environmental } \\
\text { swabs }\end{array}$ & $0 / 8$ & $0 / 8$ & $0 / 8$ & $0 / 24$ & \\
\hline Air & $0 / 8$ & $0 / 7$ & $0 / 8$ & $0 / 23$ & \\
\hline Feed & $0 / 15$ & $1 / 10$ & $2 / 13$ & $3 / 38$ & $(8 \%)$ \\
\hline Feeder contents & $0 / 0$ & $0 / 0$ & $1 / 24$ & $1 / 24$ & $(4 \%)$ \\
\hline Total & $0 / 55$ & $\begin{array}{l}4 / 49 \\
(8 \%)\end{array}$ & $\begin{array}{l}5 / 75 \\
(7 \%)\end{array}$ & $9 / 179$ & $(5 \%)$ \\
\hline
\end{tabular}

${ }^{1}$ Figures in parentheses indicate percent positive 
Table 8. Frequency of Salmonella detected from various flock 7 samples in the turkey production facility.

\begin{tabular}{|c|c|c|c|c|c|c|}
\hline \multirow[t]{2}{*}{ Sample } & \multicolumn{5}{|c|}{$\begin{array}{c}\text { Grow-out Period } \\
\text { (number positive/number sampled) }\end{array}$} & \multirow[t]{2}{*}{ Total } \\
\hline & Day 0 & Week 2 & Week 10 & Week 14 & Week 21 & \\
\hline Turkey ceca & $0 / 12^{1}$ & $0 / 16$ & $0 / 12$ & $0 / 12$ & $0 / 12$ & $0 / 64$ \\
\hline Turkey crop & $0 / 0$ & $0 / 0$ & $0 / 0$ & $0 / 0$ & $0 / 12$ & $0 / 12$ \\
\hline Litter & $0 / 6$ & $0 / 10$ & $0 / 6$ & $0 / 6$ & $0 / 5$ & $0 / 33$ \\
\hline Drinkers & $0 / 6$ & $0 / 8$ & $0 / 6$ & $0 / 6$ & $0 / 5$ & $0 / 31$ \\
\hline $\begin{array}{l}\text { Environmental } \\
\text { swabs }\end{array}$ & $0 / 14$ & $0 / 8$ & $0 / 8$ & $0 / 8$ & $0 / 8$ & $0 / 46$ \\
\hline Air & $0 / 8$ & $0 / 8$ & $0 / 7$ & $0 / 8$ & $0 / 8$ & $0 / 39$ \\
\hline Feed & $0 / 2$ & $0 / 2$ & $0 / 10$ & $0 / 4$ & $0 / 8$ & $0 / 26$ \\
\hline Feeder contents & $0 / 0$ & $0 / 10$ & $0 / 28$ & $0 / 29$ & $0 / 40$ & $0 / 107$ \\
\hline Liners & $0 / 3$ & $0 / 0$ & $0 / 0$ & $0 / 0$ & $0 / 0$ & $0 / 3$ \\
\hline Total & $0 / 51$ & $0 / 62$ & $0 / 77$ & $0 / 73$ & $0 / 98$ & $0 / 361$ \\
\hline
\end{tabular}

\footnotetext{
${ }^{1}$ turkey intestine and yolk sacs were sampled
} 
Table 9. Frequency of Salmonella detected from various flock 8 samples in the turkey production facility.

\begin{tabular}{|c|c|c|c|c|c|}
\hline \multirow[t]{2}{*}{ Sample } & \multicolumn{3}{|c|}{$\begin{array}{c}\text { Grow-out Period } \\
\text { (number positive/number sampled) }\end{array}$} & \multirow[t]{2}{*}{ Total } & \\
\hline & Week 2 & Week 15 & Week 20 & & \\
\hline Turkey ceca & $0 / 15$ & $0 / 12$ & $0 / 12$ & $0 / 39$ & $(3 \%)^{1}$ \\
\hline Turkey crop & $0 / 13$ & $0 / 12$ & $0 / 12$ & $0 / 37$ & \\
\hline Litter & $1 / 8$ & $0 / 6$ & $0 / 6$ & $1 / 20$ & $(5 \%)$ \\
\hline Drinkers & $0 / 8$ & $0 / 6$ & $0 / 6$ & $0 / 20$ & \\
\hline $\begin{array}{l}\text { Environmental } \\
\text { swabs }\end{array}$ & $0 / 6$ & $0 / 6$ & $1 / 6$ & $1 / 18$ & $(6 \%)$ \\
\hline Air & $0 / 6$ & $0 / 6$ & $0 / 6$ & $0 / 18$ & \\
\hline Feed & $0 / 8$ & $0 / 24$ & $0 / 9$ & $0 / 41$ & \\
\hline Feeder contents & $0 / 0$ & $0 / 20$ & $1 / 20$ & $1 / 40$ & $(3 \%)$ \\
\hline Total & $\begin{array}{l}1 / 64 \\
(2 \%)\end{array}$ & $0 / 92$ & $\begin{array}{l}2 / 77 \\
(3 \%)\end{array}$ & $3 / 233$ & $(1 \%)$ \\
\hline
\end{tabular}

${ }^{1}$ Figures in parentheses indicate percent positive 
Table 10. Distribution of Salmonella serotypes isolated from various samples in the turkey production facility.

\begin{tabular}{|c|c|c|c|c|c|c|c|c|c|}
\hline \multirow[t]{2}{*}{ Sample } & \multirow[t]{2}{*}{ Serotype } & \multicolumn{3}{|c|}{ Flock 5} & \multicolumn{2}{|c|}{ Flock 6} & \multicolumn{2}{|c|}{ Flock 8} & \multirow[t]{2}{*}{ Total } \\
\hline & & Week 2 & Week 10 & Week 18 & Week 13 & Week 21 & Week 2 & Week 20 & \\
\hline \multirow{2}{*}{$\begin{array}{l}\text { CECAL } \\
\text { CONTENTS }\end{array}$} & S. heidelberg & 6 & 1 & 15 & - & - & - & - & 22 \\
\hline & S. senftenberg & - & - & - & - & 1 & - & - & 1 \\
\hline \multirow[t]{4}{*}{ LITTER } & S. heidelberg & 1 & 2 & 6 & 1 & - & - & - & 10 \\
\hline & S. muenster & 1 & - & - & - & - & 1 & & 2 \\
\hline & S. senftenberg & - & - & - & 8 & - & - & - & 8 \\
\hline & S. worthington & - & - & - & - & 1 & - & - & 1 \\
\hline \multirow[t]{3}{*}{ DRINKERS } & S. anatum & 2 & - & - & - & - & - & - & 2 \\
\hline & S. heidelberg & - & 1 & 7 & - & - & - & - & 8 \\
\hline & S. muenster & - & 1 & - & - & - & - & - & 1 \\
\hline \multirow[t]{2}{*}{ SWABS } & S. heidelberg & 1 & - & 4 & - & - & - & - & 5 \\
\hline & S. muenster & - & - & - & - & - & - & 2 & 2 \\
\hline FEED & S. senftenberg & - & - & - & 2 & 2 & - & - & 4 \\
\hline \multirow{3}{*}{$\begin{array}{l}\text { FEEDER } \\
\text { CONTENTS }\end{array}$} & S. muenster & - & - & - & - & - & - & 2 & 2 \\
\hline & S. worthington & - & - & - & - & 1 & - & - & 1 \\
\hline & Total & 11 & 5 & 32 & 11 & 5 & 1 & 4 & 69 \\
\hline
\end{tabular}


Table 11. Distribution of Salmonella serotypes isolated from various flock 5 samples in the turkey production facility.

\begin{tabular}{|c|c|c|c|c|c|}
\hline \multirow[t]{2}{*}{ Serotype } & \multicolumn{4}{|c|}{ Samples } & \multirow[t]{2}{*}{ Total } \\
\hline & Turkey ceca & Litter & Drinkers & $\begin{array}{c}\text { Environmental } \\
\text { swabs }\end{array}$ & \\
\hline S. heidelberg & 22 & 9 & 8 & 5 & $44(92 \%)^{1}$ \\
\hline S. muenster & 0 & 1 & 1 & - & $2 \quad(4 \%)$ \\
\hline S. anatum & 0 & 0 & 2 & 0 & $2 \quad(4 \%)$ \\
\hline Total & 22 & 10 & 11 & 5 & 48 \\
\hline
\end{tabular}

${ }^{1}$ Figures in parentheses indicate percent of total isolates 
Table 12. Distribution of Salmonella serotypes isolated from various flock 6 samples in the turkey production facility.

\begin{tabular}{lccccc}
\hline \hline Serotype & \multicolumn{2}{c}{ Samples } & \multicolumn{2}{c}{ Total } \\
& $\begin{array}{c}\text { Turkey } \\
\text { ceca }\end{array}$ & Litter & Feed & $\begin{array}{c}\text { Feeder } \\
\text { contents }\end{array}$ & \\
\hline S. senftenberg & 1 & 8 & 4 & 0 & $13(81 \%)^{1}$ \\
S. worthington & 0 & 1 & 0 & 1 & $2(13 \%)$ \\
S. heidelberg & 0 & 1 & 0 & 0 & $1 \quad(6 \%)$ \\
\hline Total & 1 & 10 & 4 & 1 & 16 \\
\hline \hline
\end{tabular}

${ }^{1}$ Figures in parentheses indicate percent of total isolates 
Table 13. Frequency of antibiotic resistant Salmonella serotypes isolated from various samples in the turkey production facility.

\begin{tabular}{|c|c|c|c|c|c|}
\hline Sample & Flock 5 & Flock 6 & Flock 8 & Total & \\
\hline Turkey ceca & $6 / 22$ & $0 / 1$ & $0 / 0$ & $6 / 23$ & $(26 \%)^{1}$ \\
\hline Litter & $0 / 10$ & $1 / 10$ & $0 / 1$ & $1 / 21$ & $(5 \%)$ \\
\hline Drinkers & $6 / 11$ & $0 / 0$ & $0 / 0$ & $6 / 11$ & $(55 \%)$ \\
\hline $\begin{array}{l}\text { Environmental } \\
\text { swabs }\end{array}$ & $1 / 5$ & $0 / 0$ & $2 / 2$ & $3 / 7$ & $(43 \%)$ \\
\hline Feed & $0 / 0$ & $0 / 4$ & $0 / 0$ & $0 / 4$ & \\
\hline Feeder contents & $0 / 0$ & $1 / 1$ & $0 / 2$ & $1 / 3$ & $(33 \%)$ \\
\hline Total & $\begin{array}{l}13 / 48 \\
(27 \%)\end{array}$ & $\begin{array}{c}2 / 16 \\
(13 \%)\end{array}$ & $\begin{array}{c}2 / 5 \\
(40 \%)\end{array}$ & $17 / 69$ & $(25 \%)$ \\
\hline
\end{tabular}

${ }^{1}$ Figures in parentheses indicate percent positive 
Table 14. Antibiotic resistance among Salmonella serotypes isolated from various flock 5 samples in the turkey production facility.

\begin{tabular}{|c|c|c|c|c|c|c|c|}
\hline \multirow[t]{2}{*}{ Sample } & \multicolumn{6}{|c|}{ Grow-out Period } & \multirow[t]{2}{*}{ Total } \\
\hline & Serotype & Frequency $^{1}$ & Serotypes & Frequency & Serotypes & Frequency & \\
\hline Turkey ceca & S. heidelberg & $0 / 6$ & S. heidelberg & $0 / 1$ & S. heidelberg & $\begin{array}{c}6 / 15 \\
(5-\mathrm{S}, \mathrm{Spt}, \mathrm{Gm}) \\
(1-\mathrm{Te}, \mathrm{S}, \mathrm{Spt} \\
\mathrm{Gm})\end{array}$ & $6 / 22(27 \%)^{2}$ \\
\hline Litter & $\begin{array}{l}\text { S. heidelberg } \\
\text { S. muenster }\end{array}$ & $\begin{array}{l}0 / 1 \\
0 / 1\end{array}$ & S. heidelberg & $0 / 2$ & S. heidelberg & $0 / 6$ & $0 / 10$ \\
\hline Drinkers & S. anatum & $\begin{array}{c}2 / 2 \\
(2-\mathrm{Te}, \mathrm{S})^{3}\end{array}$ & S. heidelberg & $0 / 1$ & S. heidelberg & $\begin{array}{c}4 / 7 \\
(2-\mathrm{S}, \mathrm{Spt}, \mathrm{Gm}) \\
(2-\mathrm{Te}, \mathrm{S}, \mathrm{Spt} \\
\mathrm{Gm})\end{array}$ & $6 / 11(55 \%)$ \\
\hline & & & S. mиеnster & $0 / 1$ & & & \\
\hline $\begin{array}{l}\text { Environmental } \\
\text { Swabs }\end{array}$ & S. heidelberg & $0 / 1$ & & & S. heidelberg & $\begin{array}{c}1 / 4 \\
(1-\mathrm{Te}, \mathrm{Sxt})\end{array}$ & $1 / 5 \quad(20 \%)$ \\
\hline Total & & $\begin{array}{c}2 / 11 \\
(18 \%)\end{array}$ & & $0 / 5$ & & $\begin{array}{l}11 / 32 \\
(34 \%)\end{array}$ & $13 / 48(27 \%)$ \\
\hline
\end{tabular}

${ }^{1}$ Antibiotic resistant isolates/total isolates

${ }^{2}$ Figures in parentheses indicate percent positive

${ }^{3}$ Number of isolates and resistant antibiotics

Te=tetracycline; $\mathrm{S}=$ streptomycin; $\mathrm{Spt}=$ spectinomycin; $\mathrm{Gm}=$ gentamycin; $\mathrm{Sxt}=$ trimethoprim/sulfmethoxazole 
Table 15. Antibiotic resistance among Salmonella serotypes isolated from various flock 6 samples in the turkey production facility.

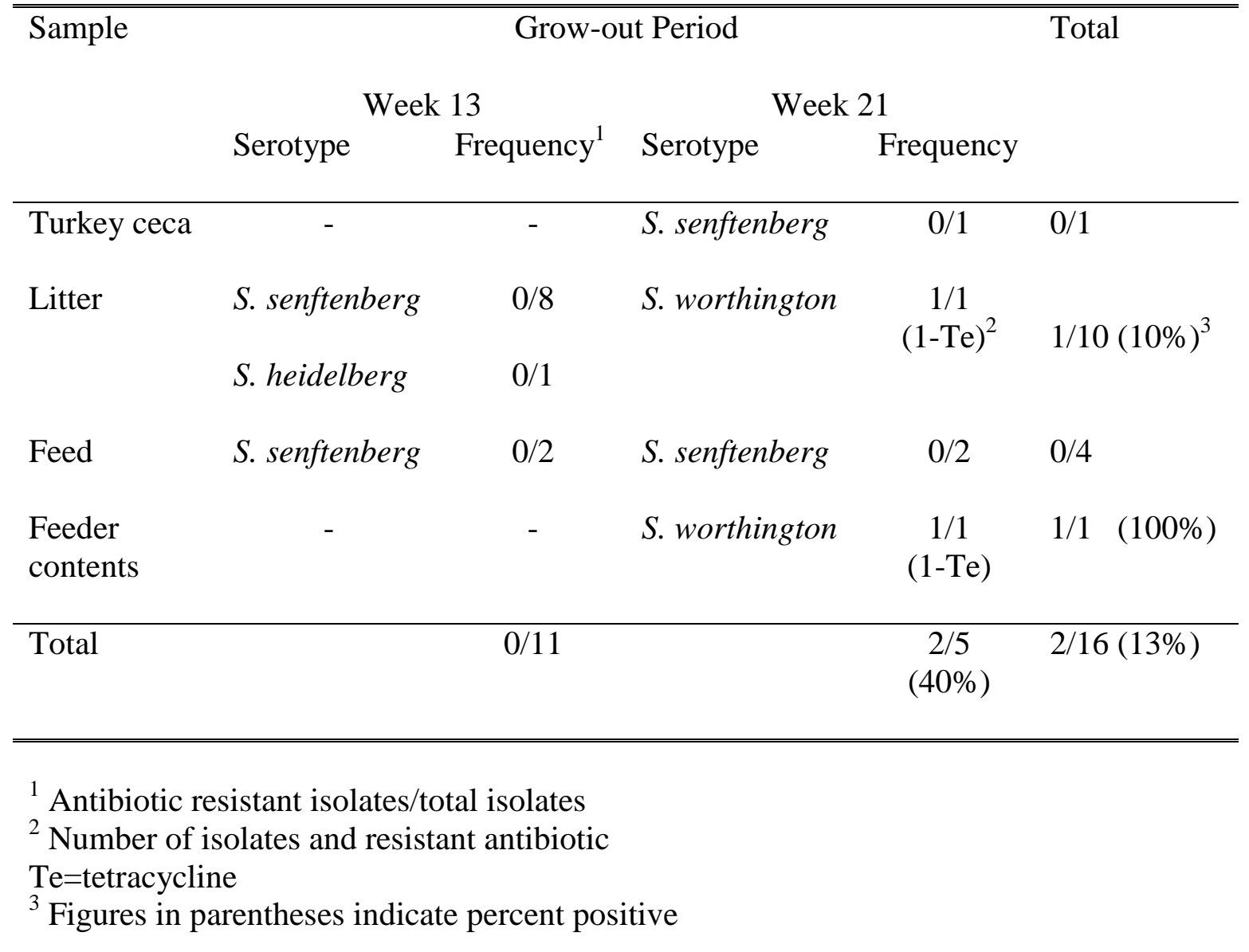


Table 16. Antibiotic resistance among Salmonella serotypes isolated from various flock 8 samples in the turkey production facility.

\begin{tabular}{|c|c|c|c|c|c|}
\hline \multirow[t]{3}{*}{ Sample } & \multicolumn{4}{|c|}{ Grow-out Period } & \multirow[t]{3}{*}{ Total } \\
\hline & \multicolumn{2}{|c|}{ Week 2} & \multirow{2}{*}{$\begin{array}{l}\text { Week } 20 \\
\text { Serotype }\end{array}$} & \multirow[b]{2}{*}{ Frequency } & \\
\hline & Serotype & Frequency $^{1}$ & & & \\
\hline Litter & S. muenster & $0 / 1$ & - & - & $0 / 1$ \\
\hline $\begin{array}{l}\text { Environmental } \\
\text { swabs }\end{array}$ & - & - & S. muenster & $\begin{array}{c}2 / 2 \\
(2-\mathrm{Tob}, \mathrm{S}, \\
\text { Spt, Gm) }\end{array}$ & $2 / 2(100 \%)^{3}$ \\
\hline $\begin{array}{l}\text { Feeder } \\
\text { contents }\end{array}$ & - & - & S. muenster & $0 / 2$ & $0 / 2$ \\
\hline Total & & $0 / 1$ & & $\begin{array}{c}2 / 4 \\
(50 \%)\end{array}$ & $2 / 5(40 \%)$ \\
\hline $\begin{array}{l}{ }^{1} \text { Antibiotic res } \\
{ }^{2} \text { Number of iso } \\
\text { Tob=tobramyci } \\
{ }^{3} \text { Figures in par }\end{array}$ & $\begin{array}{l}\text { ant isolates/to } \\
\text { tes and resist } \\
\mathrm{S}=\text { streptomy } \\
\text { heses indicat }\end{array}$ & $\begin{array}{l}\text { al isolates } \\
\text { nt antibiotics } \\
\text { in; } \mathrm{Spt}=\text { spect } \\
\text { percent posi }\end{array}$ & omycin; Gm= & entamycin & \\
\hline
\end{tabular}


Table 17. Litter $\mathrm{pH}$ and Aw measurements from pens sampled during the grow-out of flock 5

\begin{tabular}{|c|c|c|c|c|c|}
\hline \multicolumn{3}{|c|}{ "Week 10} & \multicolumn{3}{|c|}{ Week 18} \\
\hline Pen No. & PH & Aw & Pen No. & $\mathrm{pH}$ & Aw \\
\hline 1 & 7.77 & 0.945 & 2 & 6.39 & 0.961 \\
\hline 3 & 8.37 & 0.949 & 4 & 7.71 & 0.954 \\
\hline 6 & 8.35 & 0.949 & 5 & 7.33 & 0.962 \\
\hline 7 & 7.20 & 0.945 & 8 & 7.36 & 0.976 \\
\hline 9 & 7.44 & 0.966 & 10 & 7.49 & 0.991 \\
\hline 12 & 8.31 & 0.950 & 11 & 7.73 & 0.944 \\
\hline 13 & 7.38 & 0.976 & 14 & 8.21 & 0.928 \\
\hline 15 & 6.07 & 0.972 & 16 & 7.47 & 0.966 \\
\hline 18 & 5.81 & 0.976 & 17 & 8.26 & 0.938 \\
\hline 19 & 7.12 & 0.961 & 20 & 8.24 & 0.969 \\
\hline 21 & 7.94 & 0.953 & 22 & 7.77 & 0.954 \\
\hline 24 & 8.62 & 0.970 & 23 & 7.42 & 0.956 \\
\hline Average & 7.53 & 0.959 & & 7.62 & 0.958 \\
\hline
\end{tabular}


Table 18. Litter $\mathrm{pH}$ and Aw measurements from pens sampled during the grow-out of flock 6

\begin{tabular}{ccccccccc}
\hline & Week 6 & \multicolumn{3}{c}{ Week 13 } & \multicolumn{3}{c}{ Week 21 } \\
Pen No. & $\mathrm{pH}$ & Aw & Pen No. & $\mathrm{pH}$ & $\mathrm{Aw}^{1}$ & Pen No. & $\mathrm{pH}$ & $\mathrm{Aw}^{2}$ \\
\hline 1 & 7.19 & 0.990 & 3 & 7.29 & 0.982 & 2 & 8.34 & 0.886 \\
9 & 6.22 & 0.990 & 4 & 6.91 & 0.979 & 5 & 7.97 & 0.832 \\
11 & 6.34 & 0.964 & 5 & 7.40 & 0.982 & 10 & 8.16 & 0.854 \\
15 & 6.38 & 0.962 & 17 & 7.72 & 0.976 & 14 & 8.28 & 0.867 \\
22 & 7.09 & 0.976 & 18 & 7.82 & 0.988 & 19 & 7.59 & 0.918 \\
24 & 6.30 & 0.960 & 20 & 7.74 & 0.979 & 21 & 8.25 & 0.865 \\
\hline Total & 6.59 & 0.974 & & 7.48 & 0.981 & & 8.10 & 0.870 \\
\hline \hline
\end{tabular}

${ }^{1}$ Average temperature of the Aw meter $23.5^{\circ} \mathrm{C}$

${ }^{2}$ Average temperature of the Aw meter $25.4^{\circ} \mathrm{C}$ 
Table 19. Litter $\mathrm{pH}$ and Aw measurements from pens sampled during the grow-out of flock 7

\begin{tabular}{|c|c|c|c|c|c|c|c|c|c|c|c|c|c|c|}
\hline \multicolumn{3}{|c|}{ Day 0} & \multicolumn{3}{|c|}{ Week 2} & \multicolumn{3}{|c|}{ Week 10} & \multicolumn{3}{|c|}{ Week 14} & \multicolumn{3}{|c|}{ Week 21} \\
\hline Pen No & $\mathrm{pH}$ & $\mathrm{Aw}^{1}$ & Pen No & $\mathrm{pH}$ & $\mathrm{Aw}^{2}$ & Pen No & $\mathrm{pH}$ & $\mathrm{Aw}^{3}$ & Pen No & $\mathrm{pH}$ & $\mathrm{Aw}^{4}$ & Pen No & $\mathrm{pH}$ & $\mathrm{Aw}^{5}$ \\
\hline 3 & 5.24 & 0.326 & 3 & 6.02 & 0.979 & 1 & 7.48 & 0.950 & 2 & 7.38 & 0.977 & 4 & 8.33 & 0.967 \\
\hline 4 & 5.34 & 0.456 & 4 & 6.97 & 0.985 & 5 & 7.32 & 0.981 & 3 & 6.73 & 0.983 & 7 & 7.49 & 0.971 \\
\hline 10 & 5.25 & 0.377 & 9 & 6.94 & 0.967 & 8 & 7.46 & 0.966 & 6 & 7.11 & 0.987 & 16 & 7.51 & 0.914 \\
\hline 14 & 5.38 & 0.385 & 10 & 6.21 & 0.984 & 11 & 6.88 & 0.948 & 13 & 7.17 & 0.976 & 20 & 7.33 & 0.957 \\
\hline 16 & 5.26 & 0.433 & 14 & 6.77 & 0.967 & 14 & 7.67 & 0.966 & 17 & 6.46 & 0.986 & 22 & 7.85 & 0.954 \\
\hline \multirow[t]{5}{*}{22} & 5.09 & 0.482 & 15 & 7.59 & 0.975 & 15 & 8.04 & 0.960 & 18 & 6.91 & 0.966 & & & \\
\hline & & & 16 & 6.07 & 0.931 & & & & & & & & & \\
\hline & & & 20 & 5.93 & 0.982 & & & & & & & & & \\
\hline & & & 21 & 6.86 & 0.941 & & & & & & & & & \\
\hline & & & 22 & 6.16 & 0.960 & & & & & & & & & \\
\hline Avg. & 5.26 & 0.410 & & 6.55 & 0.967 & & 7.48 & 0.962 & & 6.96 & 0.979 & & 7.70 & 0.953 \\
\hline
\end{tabular}

${ }^{1}$ Average temperature of Aw meter $30.3^{\circ} \mathrm{C}$

${ }^{2}$ Average temperature of Aw meter $27.8^{\circ} \mathrm{C}$

${ }^{3}$ Average temperature of Aw meter $22.6^{\circ} \mathrm{C}$

${ }_{5}^{4}$ Average temperature of Aw meter $21.6^{\circ} \mathrm{C}$

${ }^{5}$ Average temperature of Aw meter $21.4^{\circ} \mathrm{C}$ 
Table 20. Litter $\mathrm{pH}$ and Aw measurements from pens sampled during the grow-out of flock 8

Week 2

Week 15

Week 20

Pen No. $\quad \mathrm{pH} \quad \mathrm{Aw}^{1}$ Pen No. $\mathrm{pH} \quad \mathrm{Aw}^{2}$ Pen No. $\mathrm{pH} \quad \mathrm{Aw}^{3}$

\begin{tabular}{ccccccccc}
3 & 6.30 & 0.979 & 2 & 8.35 & 0.932 & 1 & 7.02 & 0.983 \\
4 & 6.39 & 0.979 & 6 & 8.37 & 0.944 & 5 & 7.56 & 0.964 \\
9 & 6.35 & 0.983 & 12 & 7.68 & 0.953 & 11 & 7.32 & 0.963 \\
10 & 6.27 & 0.978 & 13 & 7.31 & 0.944 & 14 & 6.91 & 0.943 \\
15 & 6.25 & 0.989 & 17 & 7.66 & 0.935 & 18 & 6.68 & 0.965 \\
16 & 6.39 & 0.988 & 20 & 7.51 & 0.955 & 19 & 7.15 & 0.915 \\
21 & 6.37 & 0.990 & & & & & & \\
22 & 6.40 & 0.975 & & & & & & \\
\hline Total & 6.34 & 0.983 & & 7.81 & 0.944 & & 7.11 & 0.956 \\
\hline \hline
\end{tabular}

${ }^{1}$ Average temperature of Aw meter $25.2^{\circ} \mathrm{C}$

${ }^{2}$ Average temperature of Aw meter $22.1^{\circ} \mathrm{C}$

${ }^{3}$ Average temperature of Aw meter $24.1^{\circ} \mathrm{C}$ 
Figure 1. Turkey production facility. 


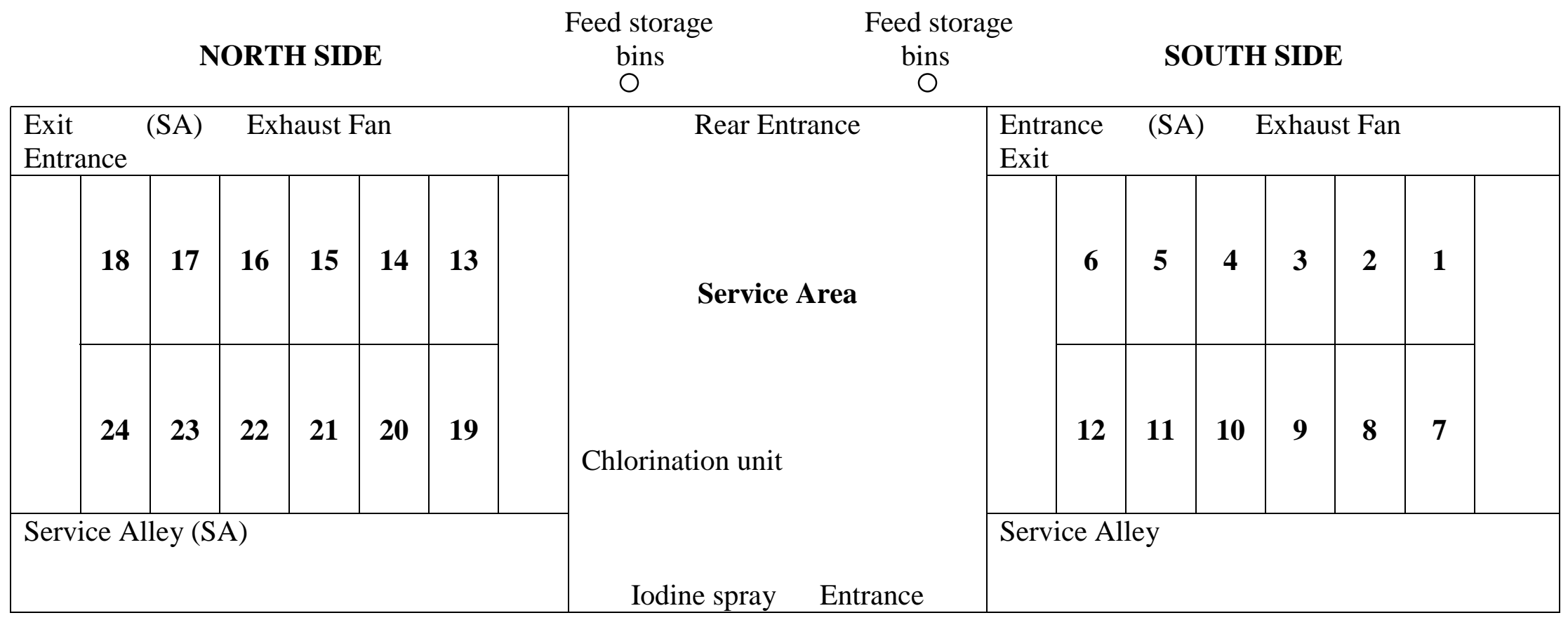


Figure 2. Maximum and minimum temperatures and percent relative humidity inside the turkey production facility in flock 6 . 


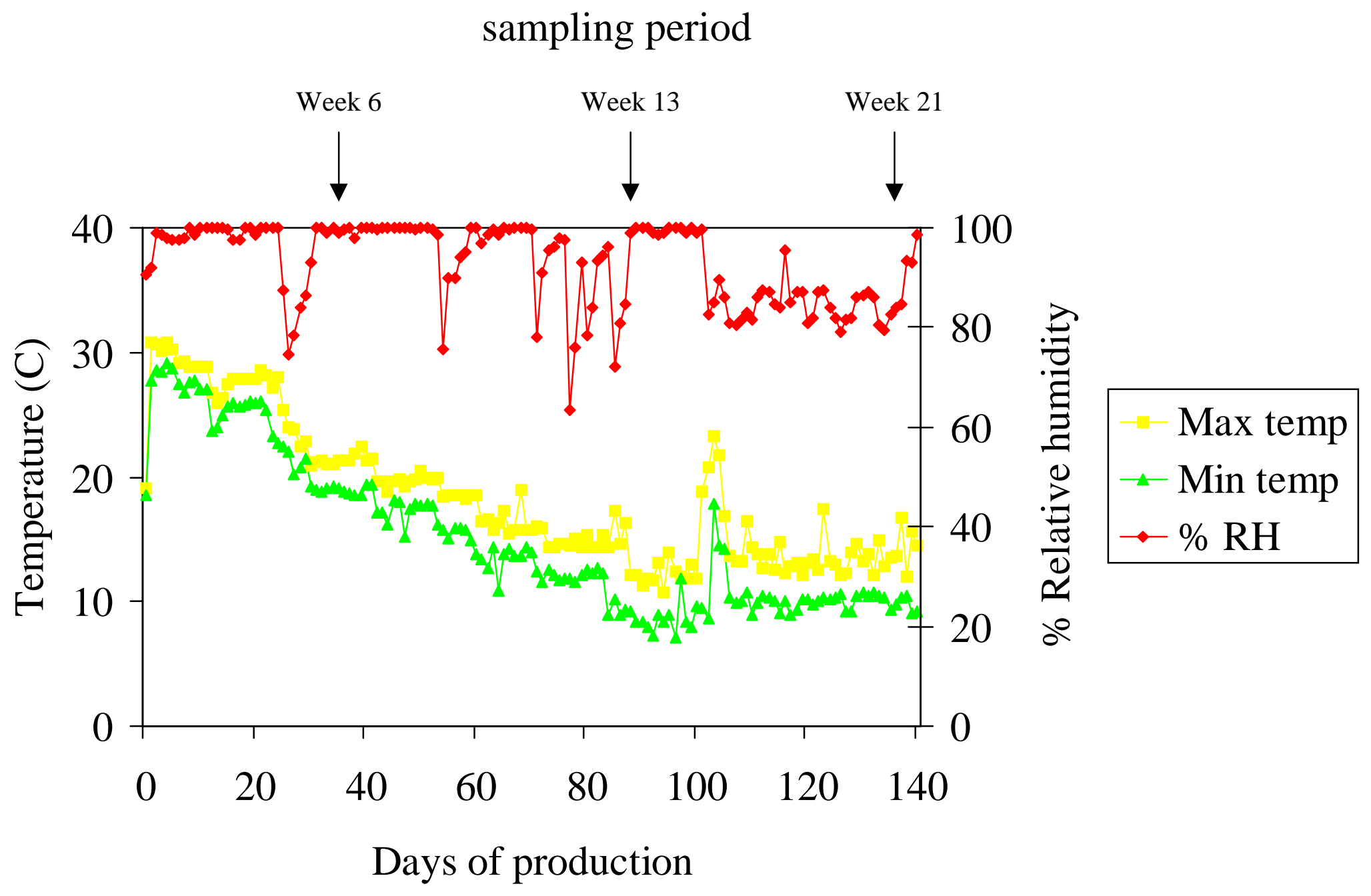


Figure 3. Maximum and minimum temperatures and percent relative humidity inside the turkey production facility in flock 7 . 
sampling period

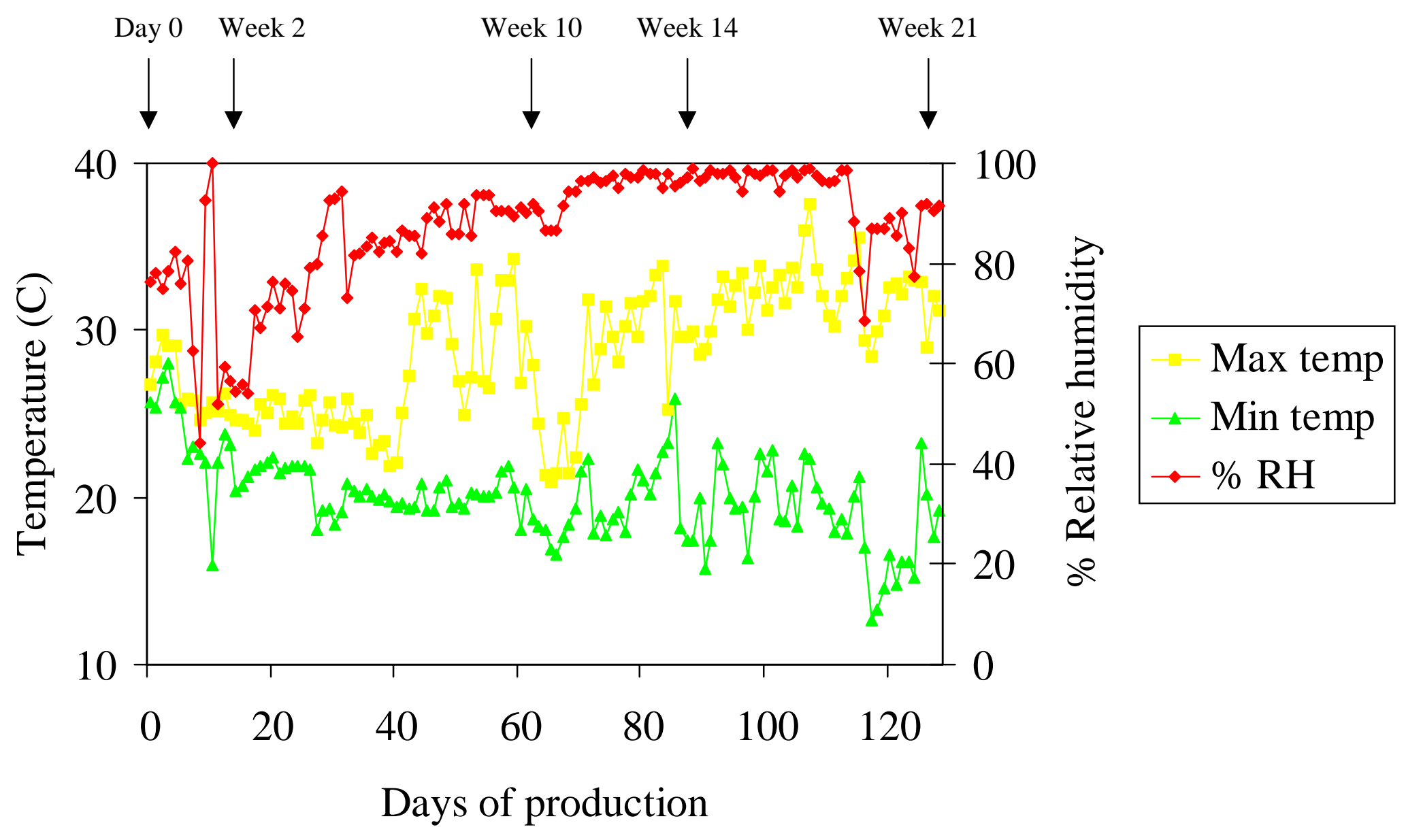


Figure 4. Maximum and minimum temperatures and percent relative humidity inside the turkey production facility in flock 8 . 


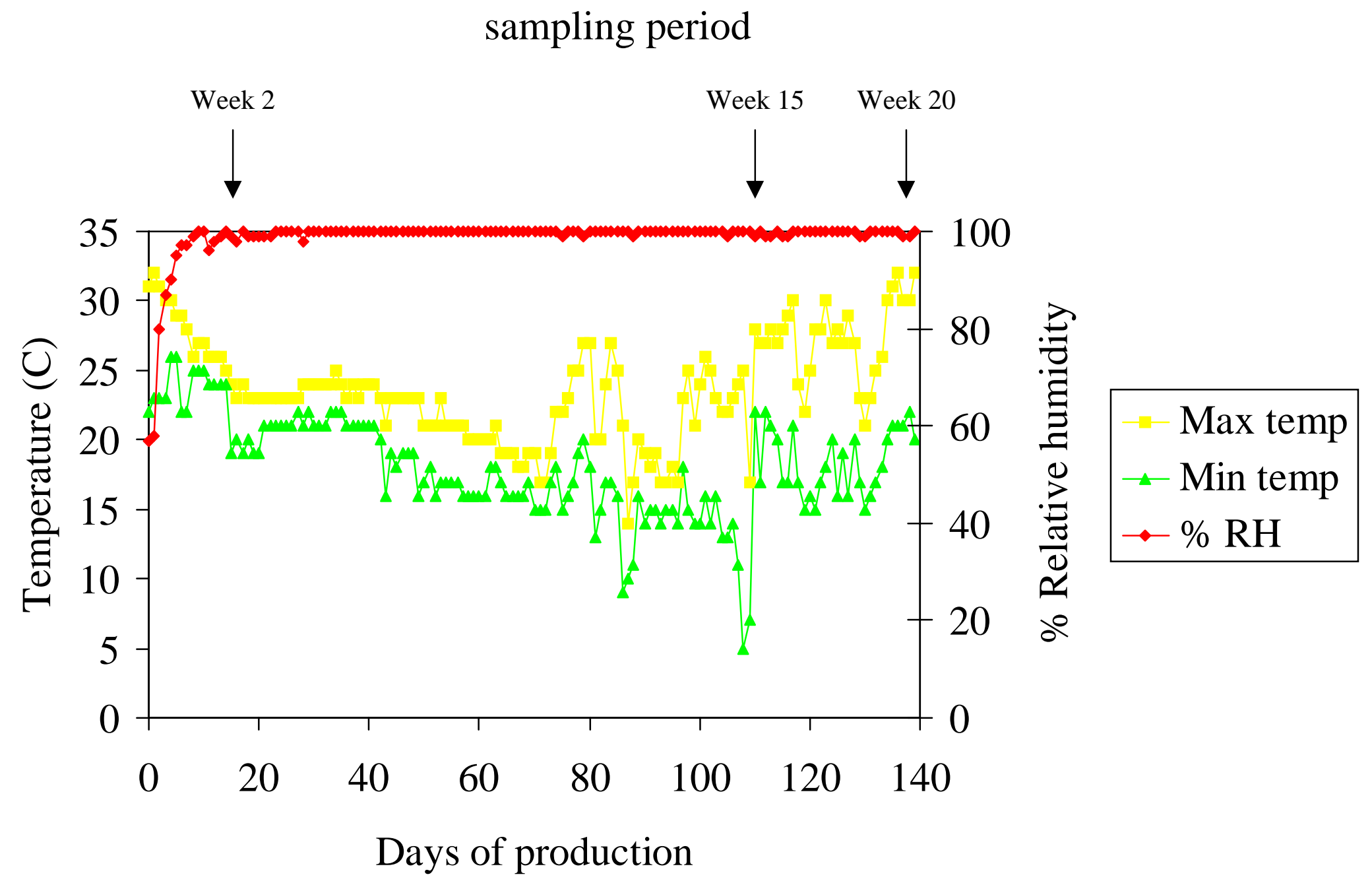


Figure 5. Prevalence of Salmonella in male and females turkeys from various flock 5 samples in the turkey production facility. 


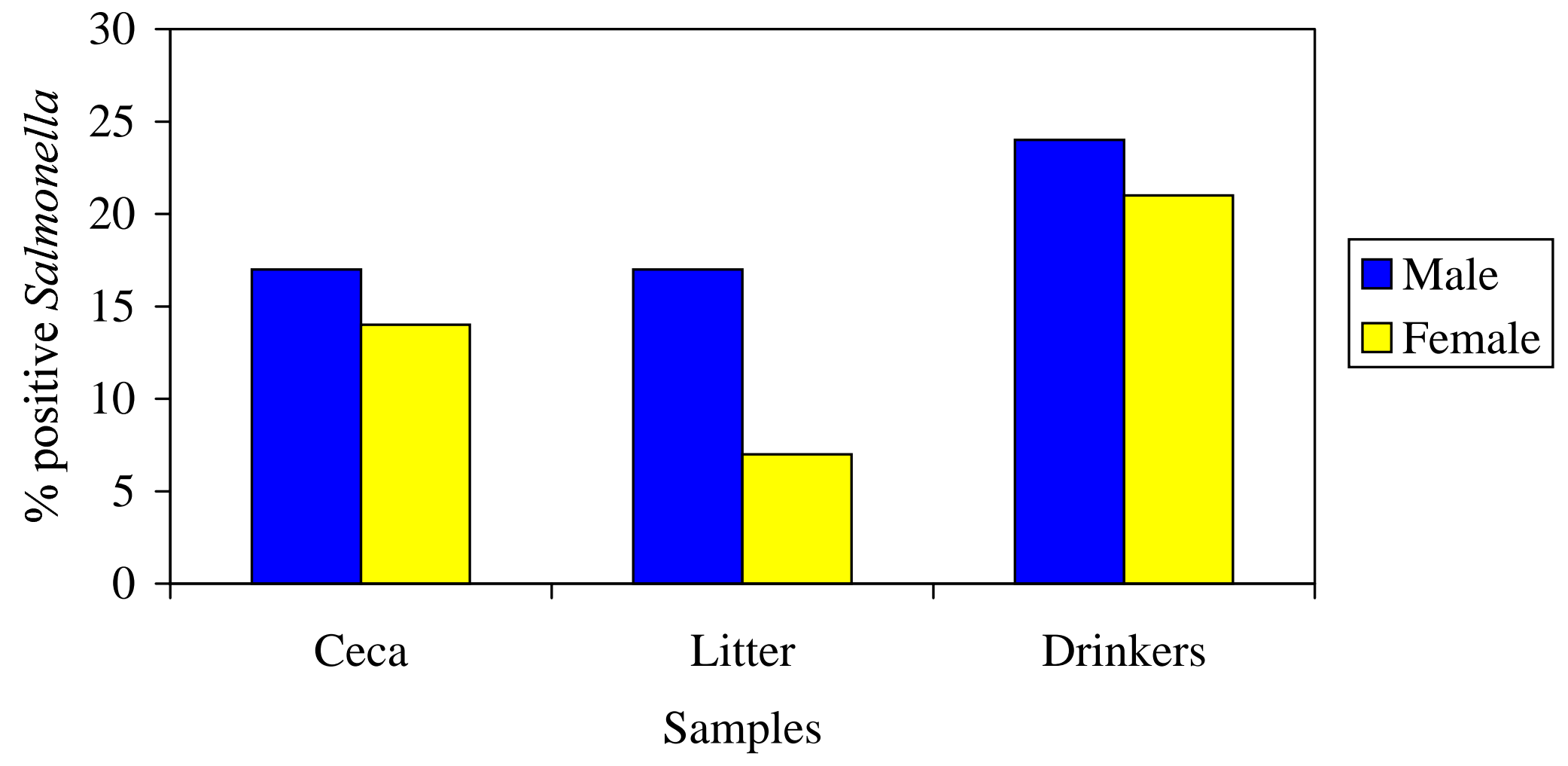


APPENDICES 


\section{FARM BIOSECURITY MEASURES}

Following biosecurity measures were implemented on the farm:

1. All barns used to brood, rear, and lay parent stock were operated on a single age, all in-all out basis. Adequate time was allowed for cleaning the facility and equipments before placement of the new flock. Building surroundings were maintained to exclude rodents, wild birds, and other wild animal that could be responsible for transmitting diseases to the birds.

2. Dead birds were removed from the general population and immediately incinerated.

3. Water supply used for drinkers was chlorinated (2-3 ppm residual chlorine) to reduce and control levels of harmful pathogens.

4. Personnel movement inside the facility was controlled. Before entering the facility all personnel were required to shower and change clothes (including footwear) that were provided by BUTA on the farm. Used clothing was washed within the service building. Before entering the turkey house, the rubber boots were rinsed with water containing iodine solution [18.05\% (alpha-(p-nonylphenyl)-omega-hydroxypoly(oxyehtylene) iodine complex; $1.75 \%$ titrable iodine and $16 \%$ phosphoric acid].

5. Vehicles transporting poults and carrying market-size birds were thoroughly cleaned and disinfected to reduce the risk of disease transmission.

Source: British United Turkeys of America (BUTA) Management Guide 


\section{TURKEY HOUSE CLEANING AND DISINFECTION METHODS}

Following measures were implemented by BUTA between placement of each flock:

1. Following removal of birds, all remaining feed from bins, augers, hoppers, lines, and feed pans were either disposed off or transferred from the farm.

2. Movable equipments such as drinkers, hoses, feed pans, and feed drops were moved to a centralized location for washing.

3. Personnel clothing from shower/dressing area was washed, dried, and placed into plastic bags for storage until next cycle.

4. A high-pressure water washer was used to rinse dust and litter from the ceiling walls, windowsills, fans, and light traps. Thorough washing was carried out later. Fan motors, electric boxes, and thermostats were dry cleaned.

5. Litter and remaining debris were swept and removed from the facility.

6. Feed tank was washed with a high pressure sprayer containing $20 \%$ chlorine bleach and the water was allowed to run out of the boot.

7. Water lines were flushed with $20 \%$ chlorinated water for $15-20 \mathrm{~min}$. The chlorinated water was allowed to sit in the water lines over night before flushing with clean water for 15-20 $\min$.

8. Turkey house (ceiling, walls, and floor) was cleaned and disinfected with high-pressure water with mild detergent before placement of new flock.

9. Feed lines and hoppers were cleaned before washing the floor so that all residual feed/dust was removed from the facility.

10. Storage, break room, and shower areas were cleaned. 
11. Equipment was removed from the facility, disassembled, and disinfected. After cleaning equipment, each piece was returned to the house for installation.

12. After all equipment was returned to the facility, all doors, and drain holes were closed and secured tightly (rodent proof).

13. Final disinfection of the premise included foaming inside and outside with a disinfectant solution. The facility was closed for at least one day before opening.

14. Upon opening the facility, insecticide and rodent bait was immediately applied and/or distributed before placement of new litter. 


\section{SALMONELLA ISOLATION PROCEDURE}

\section{Preenrichment*}

(UP broth)

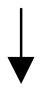

Selective enrichment*

(TT and CS broth)

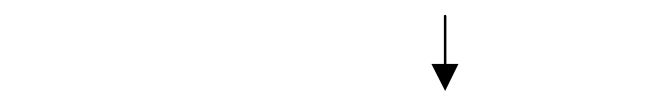

Isolation of presumptive positive colonies*

(XLT4 and BGS agar plates)

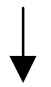

Screening of positive colonies

(TSI* and LIA** slants)

Positive cultures

maintained on $\mathrm{BHI}^{*}$

$\downarrow$

Confirmation

(Serology using polyvalent antisera)

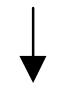

Serotyping and antibiotic resistance profile

(Salmonella Reference Center, University of Pennsylvania)

* Incubated at $37^{\circ} \mathrm{C}$ for $24 \mathrm{hr}$

** Incubated at $37^{\circ} \mathrm{C}$ for $48 \mathrm{hr}$

$\mathrm{UP}=$ universal preenrichment broth; TT=tetrathionate broth; $\mathrm{CS}=$ celenite cystine broth; XLT4=xylose lactose tergitol agar; BGS=brilliant green sulfa agar; TSI=triple sugar iron slant; and LIA=lysine iron agar slant 


\section{SAMPLED PENS}

\begin{tabular}{|c|c|c|c|c|}
\hline $\begin{array}{l}\text { Sampling } \\
\text { period }\end{array}$ & Flock 5 & Flock 6 & Flock 7 & Flock 8 \\
\hline Day 0 & & & $\begin{array}{l}3,4,10,14,16, \\
22\end{array}$ & \\
\hline Week 2 & $\begin{array}{l}3,4,5,9,10,11, \\
14,15,16,20, \\
21,22\end{array}$ & & $\begin{array}{l}3,4,9,10,14 \\
15,16,20,21 \\
22\end{array}$ & $\begin{array}{l}3,4,9,10,15 \\
16,21,22\end{array}$ \\
\hline Week 6 & & $\begin{array}{l}1,9,11,15,22, \\
24\end{array}$ & & \\
\hline Week 10 & $\begin{array}{l}1,3,6,7,9,12 \\
13,15,18,19 \\
21,24\end{array}$ & & $\begin{array}{l}1,5,8,11,14 \\
15\end{array}$ & \\
\hline Week 13 & & $\begin{array}{l}3,4,5,17,18 \\
20\end{array}$ & & \\
\hline Week 14 & & & $\begin{array}{l}2,3,6,13,17 \\
18\end{array}$ & \\
\hline Week 15 & & & & $\begin{array}{l}2,6,12,13,17, \\
20\end{array}$ \\
\hline Week 18 & $\begin{array}{l}2,4,5,8,10,11, \\
14,16,17,20 \\
22,23\end{array}$ & & & \\
\hline Week 20 & & & & $\begin{array}{l}1,5,11,14,18 \\
19\end{array}$ \\
\hline Week 21 & & $\begin{array}{l}2,5,10,14,19 \\
21\end{array}$ & $4,7,16,20,22$ & \\
\hline
\end{tabular}


BIRD DENSITY AND MORTALITY DATA

\begin{tabular}{|c|c|c|c|c|c|c|c|c|c|c|c|c|}
\hline \multirow[t]{2}{*}{ Pen No. } & \multicolumn{3}{|c|}{ Flock 5} & \multicolumn{3}{|c|}{ Flock 6} & \multicolumn{3}{|c|}{ Flock 7} & \multicolumn{3}{|c|}{ Flock 8} \\
\hline & Week 2 & Week 10 & Week 18 & Week 6 & Week 13 & Week 21 & Week 2 & Week 10 & Week 14 & Week 2 & Week 15 & Week 20 \\
\hline 1 & $0 / 78^{1}$ & $1 / 77$ & $0 / 65$ & $0 / 51$ & $0 / 47$ & $1 / 38$ & - & $0 / 70$ & $0 / 65$ & - & $0 / 50$ & $4 / 39$ \\
\hline 2 & $0 / 80$ & $0 / 80$ & $0 / 68$ & $1 / 48$ & $0 / 45$ & $1 / 34$ & - & $1 / 69$ & $1 / 63$ & - & $4 / 39$ & $4 / 29$ \\
\hline 3 & $0 / 80$ & $0 / 79$ & $1 / 55$ & $0 / 51$ & $3 / 44$ & $1 / 33$ & $0 / 168$ & $1 / 61$ & $0 / 58$ & $3 / 163$ & $2 / 50$ & $4 / 40$ \\
\hline 4 & $0 / 77$ & $0 / 76$ & $0 / 50$ & $0 / 51$ & $5 / 41$ & $1 / 31$ & $1 / 167$ & $0 / 70$ & $0 / 66$ & $2 / 162$ & $0 / 48$ & $4 / 36$ \\
\hline 5 & $0 / 79$ & $0 / 79$ & $0 / 79$ & $0 / 52$ & $2 / 49$ & $1 / 38$ & - & $0 / 70$ & $9 / 55$ & - & $4 / 40$ & $4 / 30$ \\
\hline 6 & $0 / 79$ & $0 / 78$ & $0 / 72$ & $1 / 49$ & $2 / 46$ & $1 / 37$ & - & $1 / 69$ & $9 / 57$ & - & $3 / 47$ & $4 / 38$ \\
\hline 7 & $0 / 77$ & $0 / 77$ & $0 / 70$ & $0 / 48$ & $1 / 44$ & $1 / 35$ & - & $0 / 69$ & $3 / 66$ & - & $0 / 45$ & $4 / 36$ \\
\hline 8 & $0 / 77$ & $1 / 72$ & $0 / 52$ & $0 / 48$ & $0 / 44$ & $1 / 34$ & - & $0 / 70$ & $0 / 63$ & - & $0 / 49$ & $4 / 40$ \\
\hline 9 & $0 / 80$ & $0 / 79$ & $0 / 65$ & $1 / 50$ & $0 / 45$ & $0 / 37$ & $0 / 168$ & $2 / 68$ & $0 / 64$ & $2 / 165$ & $4 / 39$ & $4 / 26$ \\
\hline 10 & $0 / 81$ & $0 / 80$ & $0 / 65$ & $0 / 50$ & $0 / 49$ & $0 / 41$ & $0 / 167$ & $0 / 70$ & $9 / 58$ & $11 / 148$ & $0 / 36$ & $0 / 36$ \\
\hline 11 & $0 / 79$ & $1 / 78$ & $0 / 56$ & $0 / 52$ & $1 / 48$ & $0 / 39$ & - & $1 / 64$ & $0 / 59$ & - & $0 / 47$ & $4 / 38$ \\
\hline 12 & $0 / 79$ & $0 / 79$ & $0 / 64$ & $1 / 49$ & $0 / 49$ & $0 / 40$ & - & $0 / 70$ & $9 / 57$ & - & $2 / 49$ & $4 / 40$ \\
\hline 13 & $0 / 80$ & $0 / 79$ & $0 / 60$ & $0 / 48$ & $1 / 45$ & $0 / 39$ & - & $0 / 62$ & $0 / 59$ & - & $6 / 60$ & $0 / 54$ \\
\hline 14 & $0 / 80$ & $0 / 78$ & $0 / 63$ & $1 / 48$ & $0 / 43$ & $1 / 34$ & $1 / 165$ & $2 / 66$ & $0 / 61$ & - & $2 / 55$ & $0 / 59$ \\
\hline 15 & $0 / 80$ & $1 / 77$ & $0 / 56$ & $0 / 52$ & $2 / 47$ & $1 / 38$ & $1 / 163$ & $0 / 69$ & $0 / 64$ & $2 / 219$ & $4 / 62$ & $0 / 56$ \\
\hline 16 & $0 / 80$ & $0 / 79$ & $0 / 58$ & $0 / 49$ & $0 / 48$ & $0 / 37$ & $0 / 168$ & $0 / 70$ & $0 / 66$ & $2 / 218$ & $4 / 60$ & $0 / 54$ \\
\hline 17 & $0 / 80$ & $1 / 79$ & $0 / 67$ & $1 / 50$ & $3 / 46$ & $1 / 36$ & - & $0 / 69$ & $9 / 54$ & - & $6 / 56$ & $0 / 48$ \\
\hline 18 & $0 / 71$ & $0 / 71$ & $0 / 43$ & $1 / 51$ & $2 / 49$ & $1 / 40$ & - & $1 / 68$ & $0 / 64$ & - & $4 / 61$ & $0 / 56$ \\
\hline 19 & $0 / 70$ & $0 / 70$ & $0 / 45$ & $1 / 48$ & $0 / 46$ & $0 / 36$ & - & $0 / 70$ & $9 / 58$ & - & $5 / 58$ & $0 / 52$ \\
\hline 20 & $0 / 80$ & $0 / 79$ & $1 / 61$ & $0 / 52$ & $3 / 43$ & $0 / 33$ & $0 / 166$ & $1 / 68$ & $0 / 63$ & - & $6 / 58$ & $0 / 52$ \\
\hline 21 & $0 / 80$ & $0 / 78$ & $0 / 52$ & $1 / 49$ & $1 / 48$ & $0 / 41$ & $0 / 168$ & $0 / 69$ & $0 / 66$ & $2 / 217$ & $4 / 60$ & $0 / 54$ \\
\hline 22 & $0 / 80$ & $0 / 79$ & $0 / 56$ & $1 / 48$ & $0 / 44$ & $1 / 34$ & $1 / 167$ & $0 / 69$ & $0 / 66$ & $2 / 222$ & $7 / 57$ & $0 / 43$ \\
\hline 23 & $0 / 80$ & $0 / 80$ & $0 / 64$ & $0 / 50$ & $0 / 47$ & $0 / 31$ & - & $0 / 69$ & $9 / 57$ & - & $4 / 59$ & $0 / 54$ \\
\hline 24 & $0 / 80$ & $0 / 80$ & $0 / 56$ & $1 / 51$ & $0 / 48$ & $0 / 38$ & - & $0 / 68$ & $18 / 46$ & - & $3 / 61$ & $0 / 54$ \\
\hline
\end{tabular}

${ }^{1}$ Dead birds/total birds 


\section{CHAPTER 2}

NON-PATHOGENIC ESCHERICHIA COLI AND TOTAL COLIFORMS AS

INDICATORS OF FECAL CONTAMINATION IN A TURKEY

PRODUCTION FACILITY 


\begin{abstract}
An ecological survey was conducted from March 1998 to June 1999 to determine the prevalence of generic E. coli and total coliforms in two turkey flocks (F7 and F8). Flocks were sampled at weeks 10, 14, and 21 for F7 and weeks 2, 15, and 20 for F8. Number of pens sampled during each grow-out period ranged from 5 to 8. Turkey cecal and crop contents, litter, drinkers, air, feed, and feeder contents were sampled. Environmental swabs were collected from various locations in the production facility. Samples from each source were mixed with appropriate amounts of Universal Preenrichment broth, and 1-mL of this enriched sample was immediately transferred to a $3 \mathrm{M}$ Petrifilm ${ }^{\mathrm{TM}} E$. coli/coliform count plate. Plates were incubated at $37^{\circ} \mathrm{C}$ for 24 and 48 h to enumerate total coliforms and generic E. coli, respectively. Escherichia coli and total coliforms were detected from 45 and $53 \%$, respectively, of all sources sampled.

Escherichia coli and total coliforms were isolated from 99 and 100\% of cecal contents, 97 and $100 \%$ of drinkers, 81 and $95 \%$ of litter, 63 and $76 \%$ of crop contents, 48 and $52 \%$ of swabs, and 18 and $33 \%$ of feeder content samples, respectively. Frequency of E. coli detection decreased in both flocks as the grow-out period progressed. Identifying preharvest sources of generic E. coli and total coliform contamination will help poultry producers and integrators to take necessary control measures in implementing good manufacturing practices within the production facilities. On-farm E. coli reduction will assist processors in reducing positive carcasses at the plant.
\end{abstract}

KEY WORDS: $E$. coli, preharvest sources, total coliforms, turkey 


\section{INTRODUCTION}

Generic (non-pathogenic) E. coli has been used as an indicator organism and its presence indicates a failure in good manufacturing practices at the processing plant. This failure could result in a food product of unacceptable microbial quality (Johnson, 1995). Generic E. coli is ubiquitous to the gastrointestinal tract of chickens and turkeys and serves as a microbial indicator of fecal contamination on poultry carcasses. Fecal contamination, in turn, may be responsible for transmitting enteric pathogens such as E. coli O157:H7, Salmonella, and Campylobacter on fresh poultry. Solberg et al. (1977) reported practical implications of using E. coli as an indicator of pathogens in raw poultry. The authors demonstrated that if a raw food product contained less than 3 cells of $E$. coli/g, then $7 \%$ of the product will contain pathogens. Similarly, if the raw food contained $<10^{2}, 10^{3}$, or $10^{4}$ E. coli cells/g, then 42,52 , and $59 \%$ of the product, respectively, will contain pathogens. Studies have shown that verotoxigenic (or enterohemorrhagic) E. coli $\mathrm{O} 157: \mathrm{H} 7$, a major serotype of generic $E$. coli infections, has been reported predominantly in live beef and dairy cattle resulting from on-farm contamination and/or contamination at the processing units (Hinton et al., 1985; Sischo and Hancock, 1994; Garber et al., 1995; Johnson et al., 1995; Hancock et al., 1997; Wells et al., 1998). Gill et al. (1996) demonstrated that enumerating $E$. coli could be valuable in assessing plant sanitary conditions during beef slaughter. Although E. coli-related food borne outbreaks have been associated with raw beef products, raw and processed poultry products should not be excluded.

Federal guidelines stipulate testing of $E$. coli levels on poultry carcasses at the slaughter facility. According to the "Mega-Reg" policy initiated by the Food Safety and Inspection Service (FSIS), meat and poultry slaughtering facilities are required to implement Hazard Analysis and Critical Control Point (HACCP) protocols and conduct testing of generic E. coli on 
carcasses to ensure process control (Anon, 1996). Escherichia coli testing has been carried out using AOAC-approved methods. Regulation requires smaller plants (annually producing 440,000 chickens or 60,000 turkeys) to collect one sample (whole bird rinse after the drip line) per week during the months of June to August (Anon, 1996). Larger plants are required to collect one sample every 22,000 chickens or 3,000 turkeys. Chickens have a lower limit of 100 $\mathrm{CFU} / \mathrm{cm}^{2}$ and an upper limit of $10,000 \mathrm{CFU} / \mathrm{cm}^{2}$. Limits have not been set for turkeys. No result can exceed the upper limit, and only three of fewer samples are allowed in the range from 100 to $10,000 \mathrm{CFU} / \mathrm{cm}^{2}$ from the last 13 samples.

However, to facilitate process control at the slaughtering plant, comprehensive control should be implemented at the production facilities. One way of implementation is to identify preharvest sources of generic E. coli and total coliforms so that critical control points could be established, preharvest, to reduce their incidence. The objective of this study was to identify key environmental sources/vectors in a turkey production facility that may contribute to generic $E$. coli and total coliform contamination of poultry.

\section{MATERIALS AND METHODS}

The survey was conducted at Reymann Memorial Farm, Wardensville, WV, in conjunction with turkey production trials supported by British United Turkeys of America (BUTA), Lewisburg, WV. The facility consists of 24 pens with 12 pens on each side of a central service area. Two turkey flocks (F7 and F8) were sampled from March 1998 to June 1999 on this facility. These are the $7^{\text {th }}$ and $8^{\text {th }}$ flocks produced in this facility. Production trials were conducted by BUTA to evaluate the effect of strain and feed (F7) and strain and gender (F8) on growth performance, feed efficiency and carcass composition of turkeys. Flock characteristics are summarized in Table 1. Standard biosecurity measures were implemented and the houses, 
pens, and equipments were thoroughly cleaned and disinfected between each flock in accordance with BUTA guidelines (Appendix, Chapter1).

\section{Sampling Procedures}

Turkey cecal and crop contents, litter, drinkers, air, feed, and feeder content were sampled during weeks 10, 14, and 21 for F7 and weeks 2, 15, and 20 for F8. Environmental swabs were collected throughout the facility. Turkeys were euthanized by cervical disarticulation within accepted guidelines. The entire cecum was removed, the blind end was snipped with a pair of scissors, and the cecal contents were transferred to a sterile stomacher bag and sealed. Litter and drinker samples were collected from the same pens used for sampling turkeys. Litter samples were collected from 5-6 random locations within the pen and a composite sample was tested. For water samples, 2 or 3 strips of sterile cloth gauzes were dipped into drinker water and these gauzes were transferred to sterile bags and sealed. Environmental swabs were collected from a $16 \mathrm{~cm}^{2}$ area using a sterile swab template; swabs were transferred to $10 \mathrm{~mL}$ UP broth. The locations for swab samples included walls, ventilation fans, feathers and open wounds of sick birds, feathers of dead birds, employee shoes, fans inside the pens, feed storage bins, and door handles. Air samples were collected using Rodac plates containing brain heart infusion (BHI) agar with a SAS portable high flow air sampler (Model 5203, Spiral Biotech Inc., Maryland). The air sampler was set to withdraw $60 \mathrm{~L}$ of air in $20 \mathrm{~s}$. Air samples were collected from pens, ventilation fans, entrances to the turkey house, centralized service area, and service area on each side of the turkey house during each production period. After collecting the air samples on rodac plates, BHI agar was aseptically transferred to a sterile stomacher bag and sealed. Feed samples were randomly collected from each feed shipment by placing a sterile bag in the feed flow from the auger and/or from the feed cart. Feeder content 
samples included feed weighback samples collected from each of 24 pens per week. Samples were stored at $-4^{\circ} \mathrm{C}$ in the facility. About 10 to $20 \%$ of the feeder samples were analyzed during each sampling period. Samples were shipped to the laboratory on ice to minimize E. coli growth.

\section{Laboratory procedures}

Samples of turkey ceca and crop contents were thoroughly mixed with UP broth (1:10 w/v). Drinker and air samples were mixed with $100 \mathrm{~mL}$ of UP broth and massaged manually for $30 \mathrm{~s}$. Approximately $5 \mathrm{~g}$ of litter, $10 \mathrm{~g}$ of feed or $10 \mathrm{~g}$ of feeder content samples were transferred to specimen bottles containing $100 \mathrm{~mL}$ UP broth and mixed. Bacterial counts from these sources are expressed as $\log \mathrm{CFU} / \mathrm{mL}$ of UP broth. Swab samples, placed in $10 \mathrm{~mL}$ UP broth, were directly used for E. coli testing. A Petrifilm ${ }^{\mathrm{TM}}$ E. coli/coliform count plate (Microbiology Products 3M Health Care, Minnesota) for enumerating generic $E$. coli and total coliforms was placed on a leveled surface (Appendix). The top film was lifted and 1-mL of freshly mixed sample was placed at the center of the bottom gel. The top film was rolled down slowly ensuring no air bubbles were entrapped. A plastic spreader was placed on the center of the plate and the sample was distributed evenly by applying gentle pressure on the center of the spreader. The spreader was removed and the gel was allowed to solidify for $1 \mathrm{~min}$. The $3 \mathrm{M}$ Petrifilm ${ }^{\mathrm{TM}}$ plates were incubated (Imperial II Incubator 422, Labline Instruments Inc., Illinois) at $37^{\circ} \mathrm{C}$ for $24 \pm 2 \mathrm{~h}$ to enumerate total coliforms and incubated for an additional $24 \pm 2 \mathrm{~h}$ at $37^{\circ} \mathrm{C}$ to enumerate generic E. coli colonies. The total coliform count consisted of bright red and blue colonies, and these colonies were closely associated ( 1 colony diameter) with entrapped gases. Escherichia coli colonies appeared blue or red-blue with or without gas regardless of size or intensity of color. All red and blue colonies were counted to obtain a total coliform count. The entire procedure 
described above was carried out under aseptic conditions using a laminar flow unit (Model NU425-400, Class II Type A/B3, NuAireTM Inc., Minnesota). Matner and coworkers (1990)

reported that the Petrifilm ${ }^{\mathrm{TM}}$ plate count method was as good as or better than AOAC-approved Most Probable Number (MPN) method for detecting generic E. coli and total coliforms in several food products.

\section{RESULTS AND DISCUSSION}

Of the 481 sources sampled from both flocks, 45 and $53 \%$ tested positive for generic $E$. coli and total coliforms, respectively. Generic E. coli and total coliforms were isolated from 99 and $100 \%$ of turkey ceca, 63 and $76 \%$ of turkey crop, 81 and $95 \%$ of litter, 97 and $100 \%$ of drinkers, 48 and $52 \%$ of environmental swabs, 0 and $10 \%$ of air, 0 and $3 \%$ of feed, and 18 and $33 \%$ of feeder content samples, respectively. Prevalence of generic E. coli has been used in assessing sanitary control of the turkey slaughtering process (USDA, 1996). According to the United States Department of Agriculture (USDA), E. coli testing would verify that the slaughtering process was reducing or preventing fecal contamination on carcasses (USDA-FSIS, 1996). Unsanitary conditions on turkey farms could be responsible for harboring E. coli and fecal coliforms, contributing to transmission at the slaughter facilities. Escherichia coli was selected as the test organism because enumerating $E$. coli could assist in verifying that processing parameters were in control. In addition, detection and quantification of $E$. coli is simple and inexpensive compared to other poultry pathogens such as Salmonella, Campylobacter, and Listeria (Russell, 1996).

In F7, E. coli was detected from $100 \%$ each of turkey ceca, litter, and drinkers, $75 \%$ of crop contents, $50 \%$ of environmental swabs, and $26 \%$ of feeder content samples (Table 2). Escherichia coli remained undetected in air and feed samples. Frequency of detection decreased 
from $55 \%$ at week 10 to $41 \%$ at week 21 of the grow-out period. Since E. coli inhabits the gastrointestinal tract, high levels (> $7.0 \log \mathrm{CFU} / \mathrm{mL}$ ) would be expected in turkey ceca and crop contents. Escherichia coli found in drinker samples ranged from $<1.0$ to $7.0 \log \mathrm{CFU} / \mathrm{mL}$, and low counts were observed in environmental swabs $\left(<1 \log \mathrm{CFU} / \mathrm{cm}^{2}\right)$ and feeder contents $(<1$ to $2.4 \log \mathrm{CFU} / \mathrm{mL}$ ). In F8, turkey ceca (97\%) and drinkers (95\%) were the major sources/vectors of E. coli contamination (Table 3). Generic E. coli were also detected in $65 \%$ of litter, $59 \%$ of crop contents, and $44 \%$ of environmental swabs. Levels of $E$. coli detected from these samples ranged from 1.0 to $7.0 \log \mathrm{CFU} / \mathrm{mL}$. Similar to F7, E. coli frequency decreased from $73 \%$ at week 2 to $31 \%$ at week 20 . Higher incidences of $E$. coli from litter, drinker, and feeder contents in the sampled flocks indicate that these sources could have been cross-contaminated by turkey droppings. Information on E. coli serotypes isolated from the sampled sources would be useful in delineating the possible transmission pathway. Although poultry has not been associated with E. coli infections, it is possible that serotype O157:H7 could be among the sources sampled. This strain could contaminate the birds entering the slaughter facility. Nonetheless, frequency and level of O157:H7 were not evaluated in this study. It would be worthwhile enumerating the level and frequency of $E$. coli $\mathrm{O} 157: \mathrm{H} 7$ from the sampled flocks in order to determine a correlation with generic E. coli and total coliform data from the present study.

High levels of $E$. coli can be used to predict the presence of other pathogenic bacteria such as Salmonella or Campylobacter. In other words, E. coli can be considered as an "index organism" or a reference for the presence of pathogens (Russell, 1996). In this study, prevalence of Salmonella was also determined. In F7, Salmonella could not be detected in any of the 361 sources sampled, while in F8, only $1 \%$ of the 233 sources sampled tested positive (Table 8 and 9; Chapter 1). Salmonella was isolated from $6 \%$ of environmental swabs, $5 \%$ of litter samples, and 
3\% each of turkey ceca and feeder content samples. Solberg and coworkers (1977) reported a high correlation coefficient between generic E. coli and Salmonella (0.708) and coliforms and Salmonella (0.704). No correlation could be found in the present study between the presence of E. coli/total coliforms and prevalence of Salmonella during the grow-out period. Frequency of E. coli detection will always be higher than that of pathogens such as Salmonella and Campylobacter.

Turkey ceca (100\%), litter (100\%), drinkers (100\%), and crop (83\%) were the primary sources of total coliform contamination in F7 (Table 4). Total coliforms were also isolated from $50 \%$ of environmental swabs, $46 \%$ of feeder contents, and $4 \%$ of air samples. Turkey ceca, crop, and litter samples had high total coliform counts (> $7.0 \log \mathrm{CFU} / \mathrm{mL}$ ), while swabs, air, and feeder content samples had low counts ( $<1.0$ to $2.4 \log \mathrm{CFU} / \mathrm{mL}$ ). Although E. coli-positive samples decreased in F7 during the grow-out period (Table 1), frequency of total coliforms detected decreased from $60 \%$ at week 10 to $54 \%$ at week 21 . Total coliforms include members of at least three genera: Escherichia, Klebsiella, and Enterobacter. The complex microbial ecology in the turkey intestine may have been balanced by replacement of $E$. coli in the total coliform count with Klebsiella and Enterobacter during the grow-out period in F7. In F8, total coliforms were detected in 100\% each of ceca and drinker samples, $90 \%$ of litter, $73 \%$ of crop, $56 \%$ of environmental swabs, $17 \%$ of air, and 5\% of feed samples (Table 5). Although $46 \%$ of feeder contents were tested positive for total coliforms in F7 (Table 4), no feeder content samples in F8 tested positive. Turkey ceca had high coliform counts (> $7.0 \log \mathrm{CFU} / \mathrm{mL})$, while the level of coliforms varied $(<1.0$ to $7.0 \log \mathrm{CFU} / \mathrm{mL})$ for all other sources sampled. Frequency of total coliforms detection decreased from $80 \%$ at week 2 to $43 \%$ at week 20 . 


\section{CONCLUSIONS}

Cecal contents, litter and drinker samples were the major preharvest sources/vectors of generic E. coli and total coliform contamination in the turkey production facility. Controlling these sources can help the turkey producers and integrators implement good sanitary measures on the farm. Fecal matter present on the outside of turkeys could affect $E$. coli and coliforms levels on the carcasses as these birds enter the slaughter facilities. This is regardless of sanitary conditions maintained at the processing facilities or efforts taken to decrease bacterial load during processing. Feed withdrawl and transportation stress may contribute to $E$. coli contamination before turkeys enter the processing units. These factors are not directly plant related nor are they a measure of personnel sanitation; nonetheless, under the current federal regulations, the integrators would be ultimately responsible for high levels of $E$. coli on carcasses. Since $E$. coli frequently represents the majority of total coliforms, reducing the latter in poultry carcasses could also assist in minimizing risk of $E$. coli infections. Certain serotypes of $E$. coli have been responsible for human hemorrhagic colitis and hemolytic uremic syndrome. Although many of these cases have been linked to consumption of undercooked ground beef, raw and processed poultry products are no exception. It is imperative that turkeys arriving at the slaughter facilities have reduced levels of $E$. coli and/or fecal coliforms. Eliminating generic $E$. coli or total coliforms from turkey houses is impossible because these microorganisms are ubiquitous and they form the natural microflora of the bird's gastrointestinal tract. Hence, efforts should be made in reducing their levels by implementing stringent hygienic practices at the grow-out facilities. 


\section{REFERENCES}

Anon. 1996. News and notes. Food Quality 3:7-10.

Garber, L.P., Wells, S.J., Hancock, D.D., Doyle, M.P., Tuttle, J., Shere, J.A. and Zhao, T. 1995. Risk factors for fecal shedding of Escherichia coli O157:H7 in dairy calves. J. Am. Vet. Med. Assoc. 207:46-49.

Gill, C.O., McGinnis, J.C. and Badoni, M. 1996. Use of Escherichia coli counts to assess the hygienic characteristics of a beef carcass dressing process. Intl. J. Food Microbiol. 31:181196.

Hancock, D.D., Rice, D.H., Herriott, D.E., Besser, T.E., Ebel, E.D. and Carpenter, L.V. 1997. Effects of farm manure-handling practices on Escherichia coli $\mathrm{O} 157: \mathrm{H} 7$ prevalence in cattle. J. Food Prot. 60:363-366.

Hinton, M., Linton, A.H. and Hedges, A.J. 1985. The ecology of Escherichia coli in calves reared as dairy cow replacements. J. Appl. Bacteriol. 58:131-138.

Johnson, J.L. 1995. The relationship between pathogenic bacteria and "index" organisms on meat and poultry. Institute of Food Technologists Muscle Foods Division Newsletter 22(1):2-3.

Johnson, J.L., Rose, B.E., Sharar, A.K., Ransom, G.M., Lattuada, C.P. and McNamara, A.M. 1995. Methods used for detection and recovery of Escherichia coli O157:H7 associated with a food-borne disease outbreak. J. Food Prot. 58:597-603.

Matner, R.R., Fox, T.L., McIver, D.E. and Curiale, M.S. 1990. Efficacy of Petrifilm ${ }^{\mathrm{TM}}$ E. coli count plates for E. coli and coliform enumeration. J. Food Prot. 53:145-150.

Russell, S.M. 1996. Escherichia coli: The unreliable index? Broiler Industry 10:20-24.

Sischo, W.M and Hancock, D. 1994. Prospects of pre-harvest control of bacterial foodborne disease agents. Reci. Meat Conf. Proceed. 47:37-40.

Solberg, M., Miskimin, D.K., Martin, B.A., Page, G., Goldner, S. and Libfeld, M. 1977. Indicator organisms: Food borne pathogens and food safety. Assoc. Food Drug Off. Quart. Bull. 41(1):9-21.

USDA. 1996. Pathogen reduction: hazard analysis and critical control point (HACCP) systems. Final rule. 9 CFR Part 304. 61:38805-38989.

USDA-FSIS. 1996. How USDA's new food safety system will fight bacteria that cause food borne illness. Key Facts Bulletin, July. 
Wells, S., Fedorka-Cray, P.J., Besser, T., McDonough, P. and Smith, B. 1998. E. coli O157:H7 and Salmonella status on U.S. dairy operations. National Animal Health Monitoring Systems Newsletter, May, pp 1-8. 
Table 1. Summary of turkey flock statistics

\begin{tabular}{lll}
\hline \hline Characteristics & Flock 7 & Flock 8 \\
\hline Sampling period & March to August 1998 & January to June 1999 \\
BUTA production trail & 4 strains x 2 feeds & 4 strains x 2 genders \\
Sampling frequency (weeks) & 10,14, and 21 & 2,15, and 20 \\
Number of pens & $5-6$ & $6-8$ \\
Sex of birds & Females & Males and females \\
\hline \hline
\end{tabular}


Table 2. Frequency and enumeration of generic E. coli detected from various flock 7 samples in the turkey production facility.

\begin{tabular}{|c|c|c|c|c|c|}
\hline \multirow{3}{*}{$\begin{array}{l}\text { Sample } \\
\text { Turkey ceca }\end{array}$} & \multicolumn{3}{|c|}{$\begin{array}{c}\text { Grow-out period } \\
\text { (no. positive/no. sampled) }\end{array}$} & \multirow{2}{*}{\multicolumn{2}{|c|}{$\begin{array}{l}\text { Total } \\
\text { (\% positive) }\end{array}$}} \\
\hline & \multirow{2}{*}{$\begin{array}{c}\text { Week } 10 \\
12 / 12 \\
(>7.0)^{\mathrm{a}}\end{array}$} & \multirow{2}{*}{$\begin{array}{c}\text { Week } 14 \\
12 / 12 \\
(>7.0)\end{array}$} & \multirow{2}{*}{$\begin{array}{c}\text { Week } 21 \\
12 / 12 \\
(>7.0)\end{array}$} & & \\
\hline & & & & $36 / 36$ & $(100)$ \\
\hline Turkey crop & $0 / 0$ & $0 / 0$ & $\begin{array}{c}9 / 12 \\
(>7.0)\end{array}$ & $9 / 12$ & $(75)$ \\
\hline Litter & $\begin{array}{c}6 / 6 \\
(>7.0)\end{array}$ & $\begin{array}{c}6 / 6 \\
(>7.0)\end{array}$ & $\begin{array}{c}5 / 5 \\
(>7.0)\end{array}$ & $17 / 17$ & (100) \\
\hline Drinkers & $\begin{array}{c}6 / 6 \\
(1.0-7.0)\end{array}$ & $\begin{array}{c}6 / 6 \\
(<1.0-7.0)\end{array}$ & $\begin{array}{c}5 / 5 \\
(<1.0)\end{array}$ & $17 / 17$ & $(100)$ \\
\hline $\begin{array}{l}\text { Environmental } \\
\text { swabs }^{b}\end{array}$ & $\begin{array}{c}5 / 8 \\
(<1.0)\end{array}$ & $\begin{array}{c}3 / 8 \\
(<1.0)\end{array}$ & $\begin{array}{c}4 / 8 \\
(<1.0)\end{array}$ & $12 / 24$ & $(50)$ \\
\hline Air & $0 / 7$ & $0 / 8$ & $0 / 8$ & $0 / 23$ & \\
\hline Feed & $0 / 10$ & $0 / 4$ & $0 / 8$ & $0 / 22$ & \\
\hline Feeder contents & $\begin{array}{c}13 / 28 \\
(1.0-2.4)\end{array}$ & $\begin{array}{c}7 / 29 \\
(<1.0-1.9)\end{array}$ & $\begin{array}{l}5 / 40 \\
(<1.0)\end{array}$ & $25 / 97$ & $(26)$ \\
\hline $\begin{array}{l}\text { Total } \\
\text { (\% positive) }\end{array}$ & $\begin{array}{c}42 / 77 \\
(55)\end{array}$ & $\begin{array}{c}34 / 73 \\
(47)\end{array}$ & $\begin{array}{c}40 / 98 \\
(41)\end{array}$ & $116 / 2$ & $8(47)$ \\
\hline
\end{tabular}

${ }^{a}$ expressed as range $(\log \mathrm{CFU} / \mathrm{mL})$ for number of sources sampled

${ }^{\mathrm{b}}$ counts expressed in $\log \mathrm{CFU} / \mathrm{cm}^{2}$ 
Table 3. Frequency and enumeration of generic E. coli detected from various flock 8 samples in the turkey production facility.

\begin{tabular}{|c|c|c|c|c|}
\hline \multirow[t]{2}{*}{ Sources } & \multicolumn{3}{|c|}{$\begin{array}{c}\text { Grow-out period } \\
(\text { no. positive/no. sampled })\end{array}$} & \multirow[t]{2}{*}{$\begin{array}{l}\text { Total } \\
\text { (\% positive) }\end{array}$} \\
\hline & Week 2 & Week 15 & Week 20 & \\
\hline Turkey ceca & $\begin{array}{l}15 / 15 \\
(>7.0)^{\mathrm{a}}\end{array}$ & $\begin{array}{l}12 / 12 \\
(>7.0)\end{array}$ & $\begin{array}{l}11 / 12 \\
(>7.0)\end{array}$ & $38 / 39$ \\
\hline Turkey crop & $\begin{array}{c}13 / 13 \\
(1.2-7.0)\end{array}$ & $\begin{array}{c}6 / 12 \\
(<1.0-7.0)\end{array}$ & $\begin{array}{c}3 / 12 \\
(<1.0-1.6)\end{array}$ & $22 / 37$ \\
\hline Litter & $\begin{array}{c}8 / 8 \\
(>7.0)\end{array}$ & $\begin{array}{c}4 / 6 \\
(>7.0)\end{array}$ & $\begin{array}{c}1 / 6 \\
(<1.0)\end{array}$ & $13 / 20$ \\
\hline Drinkers & $\begin{array}{c}8 / 8 \\
(>7.0)\end{array}$ & $\begin{array}{c}6 / 6 \\
(<1.0-7.0)\end{array}$ & $\begin{array}{c}5 / 6 \\
(<1.0-7.0)\end{array}$ & $19 / 20$ \\
\hline $\begin{array}{l}\text { Environmental } \\
\text { swabs }^{\text {b }}\end{array}$ & $\begin{array}{c}3 / 6 \\
(<1.0-2.0)\end{array}$ & $\begin{array}{c}1 / 6 \\
(<1.0)\end{array}$ & $\begin{array}{c}4 / 6 \\
(<1.0)\end{array}$ & (44) \\
\hline Air & $0 / 6$ & $0 / 6$ & $0 / 6$ & $0 / 18$ \\
\hline Feed & $0 / 8$ & $0 / 24$ & $0 / 9$ & $0 / 41$ \\
\hline Feeder contents & $0 / 0$ & $0 / 20$ & $0 / 20$ & $0 / 40$ \\
\hline $\begin{array}{l}\text { Total } \\
\text { (\% positive) }\end{array}$ & $\begin{array}{c}47 / 64 \\
(73)\end{array}$ & $\begin{array}{c}29 / 92 \\
(32)\end{array}$ & $\begin{array}{c}24 / 77 \\
(31)\end{array}$ & $100 / 233(43)$ \\
\hline
\end{tabular}

\footnotetext{
${ }^{a}$ expressed as range $\left(\log _{10} \mathrm{CFU} / \mathrm{mL}\right)$ for number of sources sampled

${ }^{\mathrm{b}}$ counts expressed in $\log \mathrm{CFU} / \mathrm{cm}^{2}$
} 
Table 4. Frequency and enumeration of total coliforms detected from various flock 7 samples in the turkey production facility.

\begin{tabular}{|c|c|c|c|c|}
\hline \multirow[t]{2}{*}{ Sample } & \multicolumn{3}{|c|}{$\begin{array}{c}\text { Grow-out period } \\
\text { (no. positive/no. sampled) }\end{array}$} & \multirow[t]{2}{*}{$\begin{array}{l}\text { Total } \\
\text { (\% positive) }\end{array}$} \\
\hline & Week 10 & Week 14 & Week 21 & \\
\hline Turkey ceca & $\begin{array}{l}12 / 12 \\
(>7.0)\end{array}$ & $\begin{array}{l}12 / 12 \\
(>7.0)\end{array}$ & $\begin{array}{l}12 / 12 \\
(>7.0)\end{array}$ & $36 / 36 \quad(100)$ \\
\hline Turkey crop & $0 / 0$ & $0 / 0$ & $\begin{array}{c}10 / 12 \\
(1.4->7.0)\end{array}$ & $10 / 12 \quad(83)$ \\
\hline Litter & $\begin{array}{c}6 / 6 \\
(>7.0)\end{array}$ & $\begin{array}{c}6 / 6 \\
(>7.0)\end{array}$ & $\begin{array}{c}5 / 5 \\
(>7.0)\end{array}$ & $17 / 17 \quad(100)$ \\
\hline Drinkers & $\begin{array}{c}6 / 6 \\
(1.4-7.0)\end{array}$ & $\begin{array}{c}6 / 6 \\
(2.0-7.0)\end{array}$ & $\begin{array}{c}5 / 5 \\
(1.3-1.6)\end{array}$ & $17 / 17 \quad(100)$ \\
\hline $\begin{array}{l}\text { Environmental } \\
\text { swabs }^{\text {b }}\end{array}$ & $\begin{array}{c}4 / 8 \\
(<1.0)\end{array}$ & $\begin{array}{c}3 / 8 \\
(<1.0)\end{array}$ & $\begin{array}{c}5 / 8 \\
(<1.0)\end{array}$ & $12 / 24 \quad(50)$ \\
\hline Air & $\begin{array}{c}1 / 7 \\
(<1.0)\end{array}$ & $0 / 8$ & $0 / 8$ & $1 / 23$ \\
\hline Feed & $0 / 10$ & $0 / 4$ & $0 / 8$ & $0 / 22$ \\
\hline Feeder contents & $\begin{array}{c}17 / 28 \\
(<1.0-2.4)\end{array}$ & $\begin{array}{c}12 / 29 \\
(<1.0-1.9)\end{array}$ & $\begin{array}{c}16 / 40 \\
(<1.0-1.5)\end{array}$ & $45 / 97 \quad(46)$ \\
\hline $\begin{array}{l}\text { Total } \\
\text { (\% positive) }\end{array}$ & $\begin{array}{c}46 / 77 \\
(60)\end{array}$ & $\begin{array}{c}39 / 73 \\
(53)\end{array}$ & $\begin{array}{c}53 / 98 \\
(54)\end{array}$ & $138 / 248(56)$ \\
\hline
\end{tabular}

${ }^{a}$ expressed as range $(\log \mathrm{CFU} / \mathrm{mL})$ for number of sources sampled

${ }^{\mathrm{b}}$ counts expressed in $\log \mathrm{CFU} / \mathrm{cm}^{2}$ 
Table 5. Frequency and enumeration of total coliforms detected from various flock 8 samples in the turkey production facility.

\begin{tabular}{|c|c|c|c|c|}
\hline \multirow[t]{2}{*}{ Sample } & \multicolumn{3}{|c|}{$\begin{array}{c}\text { Grow-out period } \\
\text { (no. positive/no. sampled) }\end{array}$} & \multirow[t]{2}{*}{$\begin{array}{l}\text { Total } \\
\text { (\% positive) }\end{array}$} \\
\hline & Week 2 & Week 15 & Week 20 & \\
\hline Turkey ceca & $\begin{array}{l}15 / 15 \\
(>7.0)\end{array}$ & $\begin{array}{l}12 / 12 \\
(>7.0)\end{array}$ & $\begin{array}{l}12 / 12 \\
(>7.0)\end{array}$ & $39 / 39 \quad(100)$ \\
\hline Turkey crop & $\begin{array}{c}12 / 13 \\
(1.3-7.0)\end{array}$ & $\begin{array}{c}8 / 12 \\
(<1.0-7.0)\end{array}$ & $\begin{array}{c}7 / 12 \\
(<1.0-7.0)\end{array}$ & 27/37 (73) \\
\hline Litter & $\begin{array}{c}8 / 8 \\
(>7.0)\end{array}$ & $\begin{array}{c}6 / 6 \\
(2.1-7.0)\end{array}$ & $\begin{array}{c}4 / 6 \\
(<1.0)\end{array}$ & $18 / 20 \quad(90)$ \\
\hline Drinkers & $\begin{array}{c}8 / 8 \\
(>7.0)\end{array}$ & $\begin{array}{c}6 / 6 \\
(<1.0-1.5)\end{array}$ & $\begin{array}{c}6 / 6 \\
(1.3-7.0)\end{array}$ & $20 / 20 \quad(100)$ \\
\hline $\begin{array}{l}\text { Environmental } \\
\text { swabs }^{b}\end{array}$ & $\begin{array}{c}5 / 6 \\
(<1.0-2.3)\end{array}$ & $\begin{array}{c}1 / 6 \\
(1.5)\end{array}$ & $\begin{array}{c}4 / 6 \\
(<1.0-1.3)\end{array}$ & $10 / 18 \quad(56)$ \\
\hline Air & $\begin{array}{c}3 / 6 \\
(<1.0)\end{array}$ & $0 / 6$ & $0 / 6$ & $3 / 18$ \\
\hline Feed & $0 / 8$ & $\begin{array}{c}2 / 24 \\
(<1.0)\end{array}$ & $0 / 9$ & $2 / 41$ \\
\hline Feeder contents & $0 / 0$ & $0 / 20$ & $0 / 20$ & $0 / 40$ \\
\hline $\begin{array}{l}\text { Total } \\
\text { (\% positive) }\end{array}$ & $\begin{array}{c}51 / 64 \\
(80)\end{array}$ & $\begin{array}{c}35 / 92 \\
(38) \\
\end{array}$ & $\begin{array}{c}33 / 77 \\
(43)\end{array}$ & $119 / 233(51)$ \\
\hline
\end{tabular}

${ }^{a}$ expressed as range $(\log \mathrm{CFU} / \mathrm{mL})$ for number of sources sampled

${ }^{\mathrm{b}}$ counts expressed in $\log \mathrm{CFU} / \mathrm{cm}^{2}$ 


\section{APPENDIX}




\section{INSTRUCTIONS FOR USING 3M PETRIFILM ${ }^{\mathrm{TM}}$ E. COLI/COLIFORM PLATES}

\section{STORAGE AND DISPOSAL}

Store unopened Petrifilm plate pouches at temperatures $\leq 8^{\circ} \mathrm{C}$. Allow pouches to come to room temperature before opening. To prevent exposure to moisture, do not refrigerate opened pouches. Store resealed pouches in a cool, dry place for no longer than a month. Exposure to Petrifilm plates to temperature $>25^{\circ} \mathrm{C}$ and/or humidities $\geq 50 \% \mathrm{RH}$ can affect the performance of the plates. Do not use plates with brown or orange discoloration.

\section{INSTRUCTIONS FOR USE}

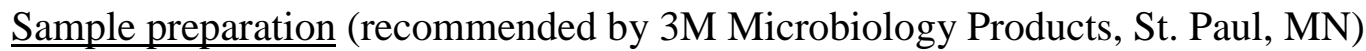

1. Use appropriate sterile diluents: Butterfield's phosphate buffer (IDF phosphate buffer, 0.0425 $\mathrm{g} / \mathrm{L} \mathrm{KH}_{2} \mathrm{PO}_{4}$, adjust to $\mathrm{pH} 7.2$ ), $0.1 \%$ peptone water, peptone salt diluent, $0.85-0.9 \%$ saline solution, thiosulfate-free letheen broth or distilled water. Do not use buffers containing citrate or sodium thiosulfate with Petrifilm plates. If citrate buffer is recommended in the procedure, substitute warmed $\left(40-45^{\circ} \mathrm{C}\right)$ Butterfield's phosphate buffer.

2. For acidic products, adjust $\mathrm{pH}$ of the diluted sample to 6.6-7.2 with $1 \mathrm{~N} \mathrm{NaOH}$. For alkaline products, adjust $\mathrm{pH}$ with $1 \mathrm{~N} \mathrm{HCl}$.

3. Blend or homogenize sample.

Plating

Inoculate and spread one Petrifilm plate before inoculating the next plate.

1. Place a Petrifilm plate on a level surface.

2. Lift the top film and dispense $1 \mathrm{~mL}$ of sample or diluted sample on the center of bottom film.

3. Slowly roll the top film down onto the sample to prevent trapping air bubbles.

4. With the smooth side down, place the plastic spreader on the center of the plate. 
5. Distribute sample evenly using a gentle downward pressure on the center of the plastic spreader. Do not slide the spreader across the film.

6. Remove spreader and leave plate undisturbed for at least one min to permit the gel to solidify.

7. Incubate plates in a horizontal position, with the clear side up in stacks of up to 20 plates. Incubator should be humidified. Moisture loss from the plate should not exceed $15 \%$ during $48 \mathrm{~h}$ of incubation.

$\underline{\text { Incubation times and temperatures }}$

1. AOAC $^{\circledR}$ official methods ( 991.14 coliform and E. coli counts in foods, dry rehydrated film methods): Incubate Petrifilm plates $48 \pm 2 \mathrm{~h}$ at $35 \pm 1{ }^{\circ} \mathrm{C}$.

2. AFNOR validated method (certificate number 3M 01/04 - 09/92): Petrifilm incubated at $24 \pm$ $2 \mathrm{~h}$ at $42 \pm 1^{\circ} \mathrm{C}$.

3. Nordic Committee on Food Analysis (NMKL) method (147.1993): For coliforms incubate Petrifilm plates at $24 \pm 2 \mathrm{~h}$ at $37^{\circ} \mathrm{C}$. For E. coli incubate at $48 \pm 2 \mathrm{~h}$ at $37^{\circ} \mathrm{C}$.

$\underline{\text { Interpretation }}$

1. Petrifilm plates can be counted on a standard colony counter or any magnified light source. Do not count colonies on the foam dam since they do not contain certain chemicals present in the gel. Do not count artifact bubbles that may be present. The interpretation of E. coli and coliform colonies on Petrifilm EC plates varies by method. Approximately $95 \%$ of E. coli produce gas.

In general, E. coli colonies are blue to red-blue and closely associated ( 1 colony dia.) with entrapped gases. Coliform colonies are bright red and closely associated ( 1 colony dia.) with entrapped gases. 
Caution: E. coli $\mathrm{O} 157: \mathrm{H} 7$ strains are atypical; they do not grow at $\geq 44.5^{\circ} \mathrm{C}$ and are glucuronidase negative. These strains will not produce a blue precipitate. They will appear as non-E. coli coliforms (red with gas).

\section{$\underline{\text { AOAC Method }}$}

Enumerate blue to red-blue colonies associated with entrapped gas, regardless of size or intensity of color, as confirmed E. coli. Blue colonies without gas are not counted as E. coli. Other coliform colonies will be red and associated with gas bubbles. Colonies not associated with gas are not counted as coliforms. The total coliform count consists of both red and blue colonies associated with gas at $24 \mathrm{~h}$. Reincubate plates for an additional $24 \pm 2 \mathrm{~h}$ at $35^{\circ} \mathrm{C}$ to detect any additional E. coli growth. Regardless of incubation time, whenever a blue colony associated with gas appears, it is a confirmed E. coli.

\section{AFNOR Method}

Blue to red-blue colonies with or without gas regardless of size or intensity of color are enumerated as E. coli.

\section{$\underline{\text { NMKL Method }}$}

Enumerate E. coli colonies as noted under AFNOR methodology. Enumeration of total coliforms at $24 \pm 2 \mathrm{~h}$ as noted under AOAC method.

2. The circular growth area is approximately $20 \mathrm{~cm}^{2}$. Estimates can be made on plates containing greater than 150 colonies by counting the number of colonies in one or more representative squares and determining the average number per square. Multiply the average number by 20 to determine total count per plate.

3. Petrifilm plates with colonies that are too numerous to count (TNTC) have one or more of the following characteristics: many small colonies, many gas bubbles, and deepening of red color 
on the gel. Higher concentrations of E. coli will cause the growth area to turn blue while high concentrations of coliforms (non-E. coli) will cause the growth area to turn dark red. When any of these occur, dilute the sample further to obtain a more accurate count.

4. Colonies may be isolated for further identification.

5. After incubation is complete, plates may be stored frozen $\left(\leq 15^{\circ} \mathrm{C}\right)$ for later enumeration for no longer than one week. 
CHAPTER 3

INHIBITION AND REVERSAL OF SALMONELLA TYPHIMURIUM ATTACHMENT TO POULTRY SKIN USING ZINC CHLORIDE 


\begin{abstract}
A skin attachment model was used to examine the ability of $\mathrm{ZnCl}_{2}$ to reverse or inhibit Salmonella attachment to broiler skin. In reversal experiments, skin samples were treated first with $1 \mathrm{~mL}$ of $S$. typhimurium suspension $\left(10^{8} \mathrm{CFU} / \mathrm{mL}\right)$ and held at room temperature for 30 min. Skin samples were then treated with 25 or $50 \mathrm{mM} \mathrm{ZnCl}_{2}$ for 5 or $15 \mathrm{~min}$. Zinc chloride solutions remained in contact with the culture during the time of application. In inhibition experiments, $\mathrm{ZnCl}_{2}$ solutions were first added; treatment solutions were discarded after 5 or 15 min of application and then the culture was added. Populations of "firmly" and "loosely" attached Salmonella were enumerated. Each skin sample was blended with $20 \mathrm{~mL}$ of $0.1 \%$ peptone water for $30 \mathrm{~s}$. Cells recovered from the skin were denoted as "loosely" attached. The same skin sample was again mixed with fresh $20 \mathrm{~mL}$ of $0.1 \%$ peptone and blended for 2 min. Recovered cells were denoted as "firmly" attached. Salmonella was enumerated on Xylose Lactose Tergitol (XLT4) plates. A section of skin sample, subjected concurrently to the above treatments, was observed under a scanning electron microscope (SEM) to observe changes in skin topography and bacterial attachment. In reversal experiments, 25 and $50 \mathrm{mM} \mathrm{ZnCl}{ }_{2}$ reduced ( $\mathrm{p}<0.01)$ "firmly" attached cells by 77 and 89\%, respectively, when compared to the control (water). At 25 and $50 \mathrm{mM}$ concentrations, $\mathrm{ZnCl}_{2}$ reduced $(\mathrm{p}<0.0001)$ cells in the “discard" by 99.4 and 99.9\%, respectively. Reduction of cells in the "discard" suggests bactericidal activity of zinc on Salmonella due to contact between bacterial culture and $\mathrm{ZnCl}_{2}$ solutions during the time of application in the reversal experiments. Micrographs indicated that 25 and $50 \mathrm{mM} \mathrm{ZnCl}_{2}$ reduced (p<0.1) Salmonella attachment by 69 and 99.9\%, respectively, in the reversal experiments. Results from SEM and XLT4 enumeration of "firmly" attached cells in the reversal experiments revealed a consistent reduction in bacterial count on skin with
\end{abstract}


increasing $\mathrm{ZnCl}_{2}$ concentration. In the inhibition experiments, 25 and $50 \mathrm{mM} \mathrm{ZnCl} 2$ reduced (p<0.01) "firmly" attached cells by 82 and 91\%, respectively. Reduction of Salmonella may be attributed, in part, to the bactericidal activity of $\mathrm{ZnCl}_{2}$ in addition to detachment of the bacterial cells on skin.

KEY WORDS: Zinc chloride, Salmonella, poultry skin, attachment, micrographs 


\section{INTRODUCTION}

Contamination of poultry products with Salmonella continues to concern consumers and the poultry industry. Attention has focused on the microbiological quality of broiler carcasses and how processing procedures influence cross-contamination of carcasses. Salmonella colonizes the gastrointestinal tract of chickens and, through horizontal transmission, may contaminate other birds and eventually carcasses (Craven and Williams, 1998). Five percent of broilers entering a processing plant harbored Salmonella, and the incidence increased to $36 \%$ for processed carcasses from the same flock (Lillard, 1990).

Research is needed to find effective, safe, and affordable methods to reduce Salmonella contamination of fresh poultry. Physical and chemical methods have been tested with varying degree of success for reducing Salmonella contamination on poultry carcasses. Physical methods include air scrubbing, UV and gamma irradiation (Wolfson et al., 1994). Chemical treatments have included chlorine, chlorine dioxide, glutaraldehyde, trisodium phosphate, sodium hypochlorite, sodium metabisulfite, $\mathrm{NaCl}, \mathrm{NaOH}$, grapefruit seed extract, Tween 80 , cetyl pyridinium chloride, ozone, a combination of hydrogen peroxide and sodium bicarbonate, and organic acids such as lactic, malic, propionic, acetic, and citric acid, (Lillard, 1988; Conner and Bilgili, 1994; Dickson and Siragusa, 1994; Kim et al., 1994; Lillard, 1994; Breen et al., 1995; Hwang and Beuchat, 1995; Tamblyn and Conner, 1997; Salvat et al., 1997; Tamblyn et al., 1997; Wang et al., 1997; Coppen et al., 1998; Xiong et al., 1998a; b; Yang et al., 1998). Currently in U.S. poultry processing plants, $50 \mathrm{ppm}$ chlorine is permitted in carcass washes and immersion chillers as a commercial disinfectant (Tamblyn et al., 1997). Trisodium phosphate (8$12 \%$ ) is also approved for use in processing plants to reduce the incidence of foodborne pathogens (Tamblyn et al., 1997). Although these treatments reduce Salmonella $\left(\mathrm{CFU} / \mathrm{cm}^{2}\right)$ on 
skin, they were ineffective against bacterial cells attached to skin. Bacteria are firmly attached or entrapped in the skin before they arrive at the processing plant and are difficult to remove by rinsing (Lillard, 1990). Hence, it is necessary to devise effective methods that interfere with Salmonella attachment to poultry skin.

Limited information is available on $\mathrm{ZnCl}_{2}$ as an antimicrobial agent. Salmonella is a gram-negative organism with an outer membrane consisting of lipoproteins, lipopolysaccharides, and phospholipids. The strong negative charge on the outer surface of the membrane aids the organism in evading phagocytosis and the action of complement - two components of the host defenses. Cultures of S. typhimurium in contact with meat surfaces selectively bind to collagen fibers, particularly the reticulin type (Benedict, 1988). Salmonella exhibits adhesion properties due to type 1 pili that are sensitive to D-mannose, while the principal carbohydrate residues of collagen, glucose-galactose and galactose, do not include mannose (Lillard, 1986a; Benedict, 1988). Electropositive zinc ions may interfere with Salmonella attachment to poultry skin by selectively binding to the negative charges on the cell membrane. Zinc chloride may also indirectly interfere with Salmonella attachment by competing with specific receptor sites on the skin surface. Zinc chloride may change the conformation of surface proteins such that receptor sites on skin surfaces would no longer be exposed for Salmonella attachment. The objective of this study was to determine the efficacy of 25 or $50 \mathrm{mM} \mathrm{ZnCl}_{2}$ to reverse or inhibit attachment of Salmonella to chicken skin.

\section{MATERIALS AND METHODS}

\section{Salmonella culture}

Salmonella typhimurium (FY98-DT 12) was obtained from the National Veterinary Services Laboratory (Ames, IA). This organism was selected because it is the most frequently 
isolated serotype from raw broiler carcasses (Lillard, 1986a). Cultures were maintained on Micro-Protect beads (TS/70-B, Technical Service Consultants Ltd., Lancashire, England) and stored at $-70^{\circ} \mathrm{C}$. Two beads containing immobilized Salmonella were transferred to $5 \mathrm{~mL}$ of Universal Preenrichment (UP) broth and incubated at $37^{\circ} \mathrm{C}$ for $24 \mathrm{~h}$. Cultures were subsequently streaked on Brain Heart Infusion (BHI) agar slants, incubated at $37^{\circ} \mathrm{C}$ for $24 \mathrm{~h}$, and stored at $4^{\circ} \mathrm{C}$. Freshly inoculated slants were used as starter cultures for experiments conducted in this study.

A loopful of S. typhimurim culture, maintained on BHI slants, was added to $5 \mathrm{~mL}$ of UP broth and incubated at $37^{\circ} \mathrm{C}$ for $24 \mathrm{~h}$. This culture was streaked on a Xylose Lactose Tergitol (XLT4) plate and further incubated at $37^{\circ} \mathrm{C}$ for $24 \mathrm{~h}$. A single isolated colony ( $c a .1 \mathrm{~mm}$ dia.) was transferred from XLT4 to $100 \mathrm{~mL}$ of UP broth and incubated at $37^{\circ} \mathrm{C}$ for $18-24 \mathrm{~h}$. The cell suspension was transferred to three, $50 \mathrm{~mL}$ tubes and centrifuged at 3,000 $\mathrm{x}$ for $10 \mathrm{~min}$ at $4^{\circ} \mathrm{C}$ (Damon IEC B20A, 870 head, $8 \times 50 \mathrm{~mL}$ tube, Fisher Scientific, Pittsburgh). The supernatant in each tube was discarded and the cell pellet was washed with $25 \mathrm{~mL}$ of cold, $0.1 \%$ peptone water. Resuspended cells were re-centrifuged at $3,000 \times \mathrm{g}$ for $10 \mathrm{~min}$ at $4^{\circ} \mathrm{C}$. Supernatant was again discarded, and pellets from the three tubes were suspended in $100 \mathrm{~mL}$ of cold, $0.1 \%$ peptone water. This suspension yielded a cell count of $10^{8} \mathrm{CFU} / \mathrm{mL}$. The optical density of the culture ranged from 0.55 to 0.58 when measured at $600 \mathrm{~nm}$ using a spectrophotometer (Spectronic 20D, Milton Roy Co., New York).

\section{Skin preparation}

Skin models were prepared as described by Kim et al. (1996) with a few modifications. Skin samples were obtained from chicken drumsticks purchased at a local supermarket on the day of experiment. Drumsticks were purchased in family packs and these packs were brought to the laboratory for immediate model skin preparation. Skin pieces $\left(c a .36 \mathrm{~cm}^{2}\right)$ were cut from the 
proximal, two-thirds of the drumstick and spread evenly on a Styrofoam tray with the external surface of the skin facing up. The tray had been previously sanitized with $70 \%$ ethanol. The skin sample was placed on top of a sterile, open capped, $50 \mathrm{~mL}$ Nalgene centrifuge tube with the external surface of the skin faced inside the tube. Rubber bands were used to secure the skin section on the tube and the tube was capped (Fig. 1). A hole was inserted at the conical end of the tube for adding culture and test solutions. The above procedure was carried out in aseptic conditions using a laminar flow unit (NU425-400, Class II Type A/B3, NuAire ${ }^{\mathrm{TM}}$ Inc., Minnesota).

\section{Skin attachment model experiments}

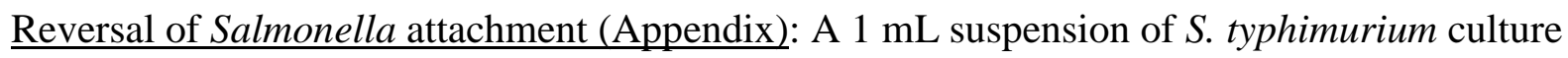
$\left(10^{8} \mathrm{CFU} / \mathrm{mL}\right)$ was added to the skin model, and attachment was allowed to take place at room temperature $\left(\sim 22^{\circ} \mathrm{C}\right)$ for $30 \mathrm{~min}$. Attachment of Salmonella to poultry tissue or skin takes place within $15 \mathrm{~s}$ and may continue up to $60 \mathrm{~min}$ after immersing the samples in a Salmonella suspension (Thomas and McMeekin, 1984; Lillard, 1985; 1986a; b). A treatment solution (sterile) of $5 \mathrm{~mL}$ water (control), $25 \mathrm{mM} \mathrm{ZnCl}_{2}$ or $50 \mathrm{mM} \mathrm{ZnCl} 2$ was added to the tube containing the bacterial suspension. Skin samples were exposed to treatments at room temperature for either 5 or $15 \mathrm{~min}$. The mixture of treatment solution and cell suspension was drained from the skin model for 2-3 min in $10 \mathrm{~mL}$ sterile tubes. The mixture was serially diluted and populations of Salmonella were designated as "discard" cells. "Discard" pH was measured with a pH meter (Model 350, Corning Inc., New York). The skin sample was cut along the outer circumference of the tube $\left(\mathrm{ca} .8 .8 \mathrm{~cm}^{2}\right)$ using a sterile scalpel blade. Each skin sample was placed in a sterile stomacher bag containing $20 \mathrm{~mL}$ of $0.1 \%$ peptone water and massaged in a stomacher blender (Model 400, Tekmer, Ohio) at $230 \mathrm{rpm}$ for $30 \mathrm{~s}$. Cells present in the wash 
solution at this point were denoted as "loosely" attached cells. Aliquots of the skin wash solution were serially diluted and spread plated in duplicate on XLT4 agar to enumerate $S$. typhimurium. The same skin sample was transferred to $20 \mathrm{~mL}$ of fresh $0.1 \%$ peptone water and massaged in a stomacher at $260 \mathrm{rpm}$ for $2 \mathrm{~min}$. Cells present in the wash solution at this point were denoted as "firmly" attached. Inhibition of Salmonella attachment (Appendix): Attachment of skin pieces to sterile $50 \mathrm{~mL}$ centrifuge tubes was carried out as described in the previous experiment. Skin samples were treated with $5 \mathrm{~mL}$ water (control), $25 \mathrm{mM} \mathrm{ZnCl}_{2}$ or $50 \mathrm{mM} \mathrm{ZnCl}_{2}$ and held at room temperature for 5 or $15 \mathrm{~min}$. Each treatment solution was allowed to drain for 2-3 min and $\mathrm{pH}$ of the solution was measured. One $\mathrm{mL}$ of S. typhimurium suspension $\left(10^{8} \mathrm{CFU} / \mathrm{mL}\right)$ was then applied to each skin sample. Attachment was allowed to take place for $30 \mathrm{~min}$ at room temperature. The culture was drained for 2-3 min, and the bacterial count was designated as "discard." The skin sample was cut from the tube around its circumference. "Loose" and "firmly" attached cells on the skin sample were enumerated as described in the reversal experiment.

One family pack, consisting of 14-16 drumsticks, was used for each replication nested within mechanism of action (reversal versus inhibition). For each treatment combination, skin samples were taken from different drumsticks. Skin samples from 12 different drumsticks (six for enumerating Salmonella using the model study and six for electron microscope studies) came from the same drumstick tray. In order to determine a reference baseline, Salmonella was enumerated on one skin sample, without treatment, from each family pack. In the reversal and inhibition experiments, each treatment combination was carried out with two separate Nalgene centrifuge tubes. The skin sample from one tube was used for enumerating viable cells on XLT4 while the skin sample from the other tube was used to directly enumerate cells using scanning 
electron microscopy (SEM). The skin model experiments were performed first and then a fresh set of tubes was used for SEM studies.

\section{Scanning electron microscopy}

Electron microscopy was carried out using the procedure described by Kim and Doores (1993a; b). Skin sample (ca. $\left.1 \mathrm{~cm}^{2}\right)$ from each treatment was cut and pinned on a wooden cork such that the external skin surface faced outwards. Bacterial cells were fixed on skin sample by placing each skin in $3 \%$ glutaraldehyde in $0.15 \mathrm{M}$ sodium cacodylate buffer $(\mathrm{pH} 7.1)$ at $4^{\circ} \mathrm{C}$ for 8 to $12 \mathrm{~h}$. Samples were washed with distilled water and dehydrated in a graded series of 50, 60, $70,80,95$, and $100 \%$ ethanol (15 min at each ethanol concentration). Specimens were finally dehydrated twice with $100 \%$ ethanol for $15 \mathrm{~min}$, washed for three, 5-min intervals with hexamethyldisilazane (HMDS) and air-dried. After complete evaporation of HMDS, skin pieces were mounted on aluminum stubs and sputter coated with $28 \mathrm{~nm}$ gold/pallidium (Model E5100, Polaron, England). Specimens were examined under a scanning electron microscope (JSM 6400, JEOL, Japan) at $20 \mathrm{kV}$ and 2,500-fold magnification. Ten fields from each treatment were examined and bacterial cells were visually counted from each field. Representative fields are shown.

\section{Experimental design}

Six incomplete blocks and treatment within each block were randomized. Each incomplete block consisted of three $\mathrm{ZnCl}_{2}$ treatments $(0,25$, or $50 \mathrm{mM})$ by two time intervals $(5$ or $15 \mathrm{~min}$ ). These six treatment combinations were replicated three times and nested within application of $\mathrm{ZnCl}_{2}$ (reversal or inhibition). Salmonella enumeration using XLT4 plates and SEM data was analyzed by ANOVA using General Linear Model (GLM) procedures (SAS, 1989; Appendix). Means were separated using least square methods. Separate analyses were 
conducted for the reversal and inhibition experiments. The following orthogonal comparisons were made: (1) without $\mathrm{ZnCl}_{2}$ vs with $\mathrm{ZnCl}_{2}$; (2) $25 \mathrm{mM} \mathrm{ZnCl}_{2}$ vs $50 \mathrm{mM} \mathrm{ZnCl}_{2}$; (3) 5 min (25 $\left.\mathrm{mM} \mathrm{ZnCl}_{2}\right)$ vs $15 \min \left(25 \mathrm{mM} \mathrm{ZnCl}_{2}\right)$; (4) $5 \min \left(50 \mathrm{mM} \mathrm{ZnCl}_{2}\right)$ vs $15 \min \left(50 \mathrm{mM} \mathrm{ZnCl}_{2}\right)$; and (5) $5 \min \left(25+50 \mathrm{mM} \mathrm{ZnCl}_{2}\right)$ vs $15 \min \left(25+50 \mathrm{mM} \mathrm{ZnCl}_{2}\right)$.

\section{RESULTS AND DISCUSSION}

There are several advantages in using a skin attachment model. Conner and Bilgili (1994) indicated that skin model techniques make it easier to evaluate the efficacy of a potential carcass disinfectant and control the optimum conditions of application. Efficacy of a disinfectant could be evaluated under pilot processing conditions in the plant prior to commercial application. An appropriate baseline measurement was made for each treatment combination to account for background Salmonella on the skin samples. Activity of $\mathrm{ZnCl}_{2}$ against the test bacterium (S. typhimurium) could be conducted while accounting for background Salmonella. In the present study, Salmonella could not be detected from the skin samples used for baseline measurements.

\section{Reversal experiments}

Limited information is available on effectiveness of $\mathrm{ZnCl}_{2}$ in reversing and/or inhibiting S. typhimurium attachment to poultry skin. This study demonstrated that increasing $\mathrm{ZnCl}_{2}$ concentration decreased $(\mathrm{p}<0.05)$ Salmonella attachment to the chicken skin. "Firmly" attached S. typhimurium cell count was reduced $(\mathrm{p}<0.01)$ from $3.94 \log \mathrm{CFU} / \mathrm{mL}$ for the control to 3.31 and $2.98 \log \mathrm{CFU} / \mathrm{mL}$ for 25 and $50 \mathrm{mM} \mathrm{ZnCl}_{2}$, respectively (Table 1). A similar trend was observed in the ability of $\mathrm{ZnCl}_{2}$ to detach "loosely" attached Salmonella to chicken skin ( $\left.\mathrm{p}<0.1\right)$. At 25 and $50 \mathrm{mM}$ concentration, $\mathrm{ZnCl}_{2}$ reduced $(\mathrm{p}<0.0001)$ cells in the "discard" by 99.4 and 99.9\%, respectively. Reduction of cells in the "discard" suggests bactericidal activity of zinc on Salmonella due to contact between bacterial culture and $\mathrm{ZnCl}_{2}$ solutions during the time of 
application in the reversal experiments. Orthogonal comparisons for the enumerated cells indicated a significant difference $(\mathrm{p}<0.05)$ between treatments with or without $\mathrm{ZnCl}_{2}($ Table 1$)$. The efficacy of $\mathrm{ZnCl}_{2}$ to detach "firmly" attached cells improved with an increase in the time of application. Zinc chloride reduced $(\mathrm{p}<0.05)$ "firmly" attached cells from $3.64 \log \mathrm{CFU} / \mathrm{mL}$ at 5 $\min$ to $3.18 \log \mathrm{CFU} / \mathrm{mL}$ at $15 \mathrm{~min}$.

\section{Inhibition experiments}

Zinc chloride was effective in interfering with attachment of S. typhimurium to chicken skin. Results from inhibition experiment indicated that "firmly" attached S. typhimurium count was reduced $(\mathrm{p}<0.01)$ from $4.39 \log \mathrm{CFU} / \mathrm{mL}$ for the control to 3.64 and $3.35 \log \mathrm{CFU} / \mathrm{mL}$ for 25 and $50 \mathrm{mM} \mathrm{ZnCl}_{2}$, respectively. Zinc treatment reduced ( $\left.<<0.05\right)$ "firmly" attached cells. Levels of $\mathrm{ZnCl}_{2}$ had no effect ( $\mathrm{p}>0.05$ ) on "loosely" attached Salmonella or cells in the "discard." Time of $\mathrm{ZnCl}_{2}$ application also did not seem to influence the detachment of Salmonella on chicken skin for the inhibition experiments.

Studies have been carried out to determine effectiveness of divalent chloride salts in reducing in vitro attachment of $S$. typhimurium to chicken cecal mucus (Craven and Willams, 1998) and Listeria monocytogenes growth (Zaika et al., 1997). These studies were carried out

using divalent cations such as calcium, magnesium, barium, iron, and manganese. Attachment of S. typhimurium to immobilized cecal mucus was inhibited by $10 \mathrm{mM}$ zinc, lanthanum, and a combination of EDTA and citrate (Craven and Williams, 1998). However, Salmonella attachment was enhanced in the presence of $10 \mathrm{mM}$ calcium, barium, and manganese ions.

\section{Effect of $\mathrm{ZnCl}_{2}$ in cell suspension}

When averaged across $\mathrm{ZnCl}_{2}$ concentration and the time of application, a combination of "firm" and "loosely" attached cells and cells in the "discard" for the reversal and inhibition 
experiments equaled 5.37 and $7.79 \log \mathrm{CFU} / \mathrm{mL}$, respectively. Although most of the cells were accounted for in the inhibition experiments, when compared to the initial inoculum volume ( 8 $\log \mathrm{CFU} / \mathrm{mL}$ ), a large reduction in the bacterial count was observed in the reversal experiments. In reversal experiments $\mathrm{ZnCl}_{2}$-treatment solutions were in contact with $S$. typhimurium culture for 5 or $15 \mathrm{~min}$, depending on the treatment combination. Unaccounted cells in reversal experiments indicated that $\mathrm{ZnCl}_{2}$ might possess bactericidal activity against $S$. typhimurium in cell suspensions. Increasing levels of $\mathrm{ZnCl}_{2}$ significantly reduced $(\mathrm{p}<0.0001) \mathrm{pH}$ of the "discarded" solutions containing the bacterial culture and $\mathrm{ZnCl}_{2}$ (Table 1). "Discard" $\mathrm{pH}$ was reduced from 6.85 for the control to 5.63 for $25 \mathrm{mM} \mathrm{ZnCl}_{2}$ and 5.45 for $50 \mathrm{mM} \mathrm{ZnCl}_{2}$. This reduction in $\mathrm{pH}$ could also be attributed to the reduction of Salmonella in cell suspension. Preliminary experiments conducted prior to this study indicated that bacterial cells tended to clump together when 25 or $50 \mathrm{mM} \mathrm{ZnCl} 2$ was added to pure Salmonella suspension (Fig. 2). Cell clumping could reduce the overall number of Salmonella colonies isolated on XLT4 agar plates. The bactericidal activity and/or the clumping effect may account for an overall reduction in Salmonella cell count by $\mathrm{ZnCl}_{2}$ treatment in the reversal experiments. The exact mechanism of action needs further investigation.

Bacterial attachment is a complex process and involves more than one mechanism. Adherence of bacteria to poultry skin depends on the bacterial strain, substratum, and environmental conditions such as medium temperature, and $\mathrm{pH}$. Butler and coworkers (1980) demonstrated that bacterial attachment takes place during the first minute of immersion; although in some instances, attachment continues over a 60 -min period. Bacterial attachment involves a two-step process (Kim and Doores, 1993a). The first step involves retention of bacteria in a liquid film on the surface of skin or meat. Bacteria are closely associated and entrapped in 
inaccessible sites by physical forces. Reversible adhesion at this stage is associated with an optimal energy balance between attractive van der Waal forces and electrostatic repulsion. The second stage involves a time-dependent, irreversible exopolymer (polysaccharides) formation by bacteria. At this stage, bacteria multiply and form a microcolony that can lead to the formation of a biofilm. Although the exact mechanism was not defined in the present study, a strong affinity of zinc ions for $S$. typhimurim cells could override the attachment of these bacterial cells to specific receptor sites on skin samples in the reversal experiments.

Zinc ions play an important role in offering protection against Salmonella infections in live birds. Hill and coworkers (1977) found that poultry dietary supplementation with $200 \mathrm{mg}$ of $\mathrm{ZnSO}_{4} / \mathrm{kg}$ of feed and $1 \mathrm{~g}$ of Na-EDTA $/ \mathrm{kg}$ of feed reduced mortality associated with $S$. gallinarum infections. Kidd and coworkers (1992) demonstrated that supplementing zincmethionine $(72 \mathrm{mg} / \mathrm{kg}$ of feed) in hen diets increased cellular immune responses in their progeny by enhancing primary antibody titers to $S$. pullorum antigen. Popova (1997) reported a significant decrease in blood zinc concentrations when pigs were challenged with $5 \times 10^{9} \mathrm{CFU}$ of S. choleraesuis. Zinc ions were found to be effective against other strains of Salmonella. Zincmethionine (30 mg/kg of feed) reduced S. arizonae incidence in turkey spleens (Kidd et al., 1994). As a future experiment, it would be interesting to challenge chicks/poults with a known inoculum volume of Salmonella and supplement drinking water with $\mathrm{ZnCl}_{2}$ to evaluate whether zinc ions offers resistance to Salmonella colonization in the gastrointestinal tract.

\section{Scanning electron microscopic studies}

The antibacterial efficacy of $\mathrm{ZnCl}_{2}$ treatments in reversing or inhibiting attachment of $S$. typhimurium to chicken skin was also evaluated by enumerating the bacterial cell count using scanning electron microscopy. Figures 3 and 4 represent micrographs of chicken skin subjected 
to different $\mathrm{ZnCl}_{2}$ treatments for the reversal and inhibition experiment, respectively. Level of $\mathrm{ZnCl}_{2}$ was effective in reducing Salmonella attached to chicken skin. Enumeration of bacterial cells on the skin samples indicated that $\mathrm{ZnCl}_{2}$ reduced $(\mathrm{p}<0.1)$ Salmonella count from $5.27 \log$ $\mathrm{CFU} / \mathrm{cm}^{2}$ for the control to $4.76 \log \mathrm{CFU} / \mathrm{cm}^{2}$ for $25 \mathrm{mM} \mathrm{ZnCl} \mathrm{Zn}_{2}$ and $2.26 \log \mathrm{CFU} / \mathrm{cm}^{2}$ for 50 $\mathrm{mM} \mathrm{ZnCl}_{2}$ (Table 1). Direct enumeration of Salmonella by SEM supports data derived from enumeration of cells using XLT4. Results from SEM and from XLT4 enumeration of "firmly" attached cells revealed a consistent reduction in Salmonella on poultry skin with increasing $\mathrm{ZnCl}_{2}$ concentration. No significant changes in the skin topography were observed between the control and $\mathrm{ZnCl}_{2}$ treatment for reversal and inhibition experiments.

Salmonella cells clustered in certain sections of the skin samples (Fig. 3d, 4a), indicating these regions were more conducive to Salmonella attachment than others. In vitro attachment of Salmonella to intestinal segments (Oyofo et al., 1989), inverted ceca (McHan et al., 1989), and immobilized cecal mucus and enterocytes (Craven et al., 1992) has been associated with type 1 fimbrae (mannose-sensitive adhesion). In addition, lipopolysaccharides play a major role in $S$. typhimurium attachment of to chicken cecal mucus (Craven, 1994). Certain skin sections may have a predominance of type 1 fimbriae and lipopolysaccharide receptor sites facilitating attachment. Immersion of poultry skin in an aqueous bacterial medium results in expansion of collagen and formation of deep channels on the skin surface or deep ridges in the muscle (Thomas and McMeekin, 1984). The authors indicated that bacteria lodged in these crevices were not visible on electron micrographs. The skin samples in the present study should have been shredded before cell enumeration to account for bacteria attached to the skin within the deep crevices. Such deep channels and crevices were observed in the present study (Fig. 3c and 4a). It is possible that these deep ridges could protect Salmonella from the treatment solution. 
Unfortunately, the skin samples were not shredded in this study, suggesting that the actual cell count could be higher than reported.

\section{CONCLUSIONS}

Zinc chloride at 25 and $50 \mathrm{mM}$ concentrations was effective in detaching "firmly" attached Salmonella on chicken skin in the reversal and inhibition experiments. Bacterial detachment was more pronounced at 15 min of $\mathrm{ZnCl}_{2}$ application in the reversal experiments. Reduction of Salmonella in cell suspension in the reversal experiments may be attributed, in part, to the bactericidal activity of $\mathrm{ZnCl}_{2}$ in addition to the $\mathrm{pH}$ and clumping effect. Data from inhibition experiments suggested that zinc ions may interfere with binding of Salmonella to receptor sites on skin surface or zinc ions may compete with Salmonella for the same receptors sites involved in the attachment process. Further studies are necessary to determine the exact mechanism of zinc ions against Salmonella attachment to poultry skin. Initial levels of attachment and a combination of time and level of $\mathrm{ZnCl}_{2}$ could influence efficacy of zinc ions as an antimicrobial agent. Since most Salmonella serotypes attach to poultry skin by the same mechanism(s), effectiveness of $\mathrm{ZnCl}_{2}$ treatments could be extended to other serotypes involved in contamination of poultry carcasses. However, the physiological characteristics of individual serotypes may influence $\mathrm{ZnCl}_{2}$ activity. In poultry processing plants antimicrobials are routinely added to the chill tank to reduce the level and frequency of pathogens on carcasses. Future investigations should determine whether $\mathrm{ZnCl}_{2}$ could effectively reduce Salmonella contamination on carcasses when added to chill water in combination with 50 ppm chlorine. The authors did not evaluate the efficacy of $\mathrm{ZnCl}_{2}$ at chill temperatures. Lower temperature may alter the skin topography and/or the dynamics by which Salmonella gets attached to skin. These alterations may affect the mechanism(s) by which $\mathrm{ZnCl}_{2}$ interferes with Salmonella attachment 
to chicken skin. The practicality of using $\mathrm{ZnCl}_{2}$ as a chemical disinfectant on poultry carcasses in a slaughter facility merits additional consideration. 


\section{REFERENCES}

Benedict, R. C. 1988. Microbial attachment to meat surfaces. Recip. Meat Conf. Proceed. 41:16.

Breen, P. J., Compadre, C. M., Fifer, E. K., Salari, H., Serbus, D. C., and Lattin, D. L. 1995. Quaternary ammonium compounds inhibit and reduce the attachment of viable Salmonella typhimurium to poultry tissues. J. Food Sci. 60:1191-1196.

Butler, J. L., Vanderzant, C., Carpenter, Z. L., Smith, G. C., Lewis, R. C. and Dutson, T. 1980. Influence of certain processing steps on attachment of microorganisms to pork skin. J. Food Prot. 43:699-705.

Conner, D. E. and Bilgili, S. F. 1994. Skin attachment model for improved laboratory evaluation of potential carcass disinfectants for their efficacy against Salmonella attached to broiler skin. J. Food Prot. 57:684-688.

Coppen, P., Fenner, S. and Salvat, G. 1998. Antimicrobial efficacy of AvGard ${ }^{\circledR}$ carcass wash $^{2}$ under industrial processing conditions. Brit. Poultry Sci. 39:229-234.

Craven, S. E. 1994. Altered colonizing ability for the ceca of broiler chicks by lipopolysaccharide-deficient mutants of Salmonella typhimurium. Avian Dis. 38:401-408.

Craven, S.E., Cox, N.A., Bailey, J.S. and Blankenship, L.C. 1992. Binding of Salmonella strains to immobilized intestinal mucosal preparations from broiler chickens. Avian Dis. 36:296-303.

Craven, S. E. And Williams, D. D. 1998. In vitro attachment of Salmonella typhimurium to chicken cecal mucus: Effect of cations and pretreatment with Lactobacillus spp. isolated from the intestinal tracts of chickens. J. Food Prot. 61:265-271.

Dickson, J.S. and Siragusa, G.R. 1994. Survival of Salmonella typhimurim, Escherichia coli O157:H7 and Listeria monocytogenes during storage on beef sanitized with organic acids. J. Food Safety 14:313-327.

Hill, R., Smith, I. M. and Leech, F. B. 1977. The effect of dietary supplements of copper, zinc and iron sulphates alone or with a chelator on survival in experimental fowl typhoid in the chick. Avian Pathol. 6:425-434.

Hwang, C. and Beuchat, L. R. 1995. Efficacy of selected chemicals for killing pathogenic and spoilage microorganisms on chicken skin. J. Food Prot. 58:19-23.

Kidd, M. T., Anthony, N. B. and Lee, S. R. 1992. Progeny performance when dams and chicks are fed supplemental zinc. Poultry Sci. 71:1201-1206. 
Kidd, M. T., Qureshi, M. A., Ferket, P. R. and Thomas, L. N. 1994. Dietary zinc-methionine enhances mononuclear-phagocytic function in young turkeys: Zinc-methionine immunity and Salmonella. Biological Trace Element Research. 42:217-229.

Kim, J-W. and Doores, S. 1993a. Attachment of Salmonella typhimurium to skins of turkey that had been defeathered through three different systems: Scanning electron microscopic examination. J. Food Prot. 56:395-400.

Kim, J-W. and Doores, S. 1993b. Influence of three defeathering systems on microtopography of turkey skin and adhesion of Salmonella typhimurium. J. Food Prot. 56:286-291, 305.

Kim, J-W., Slavik, M.F. and Bender, F.G. 1994. Removal of Salmonella typhimurium attached to chicken skin by rinsing with trisodium phosphate solution: Scanning electron microscopic examination. J. Food Safety 14:77-84.

Kim, K. Y., Frank, J. S. and Craven, S. E. 1996. Attachment of Salmonella on modified poultry skin surface. J. Food Sci. 61:442-443, 448.

Lillard, H.S. 1985. Bacterial cell characteristics and conditions influencing their adhesion to poultry skin. J. Food Prot. 48:803-807.

Lillard, H. S. 1986a. Role of fimbriae and flagella in the attachment of Salmonella typhimurium to poultry skin. J. Food Sci. 51:54-56, 65.

Lillard, H.S. 1986b. Distribution of "attached" Salmonella typhimurium cells between poultry skin and a surface film following water immersion. J. Food Prot. 49:449-454.

Lillard, H.S. 1988. Effect of surfactant or changes in ionic strength on the attachment of Salmonella typhimurium to poultry skin and muscle. J. Food Sci. 53:727-730.

Lillard, H. S. 1990. The impact of commercial processing procedures on the bacterial contamination and cross-contamination of broiler carcasses. J. Food Prot. 53:202-204.

Lillard, H. S. 1994. Effect of trisodium phosphate on salmonellae attached to poultry skin. J. Food Prot. 57:465-469.

McHan, F., Cox, N.A., Blankenship, L.C. and Bailey, J.S. 1989. In vitro attachment of Salmonella typhimurium to chick ceca exposed to selected carbohydrates. Avian Dis. 33:340344.

Oyofo, B.A., Droleskey, R.E., Norman, J.O., Mollenhauer, H.H., Ziprin, R.L., Corrier, D.E. and Deloach, J.R. 1989. Inhibition by mannose of in vitro colonization of chicken small intestine by Salmonella typhimurium. Poultry Sci. 68:1351-1356.

Popova, E. M. 1997. Blood chemistry in piglets with experimental salmonellosis. Visnik Agrarnoi Nauki. 4:52-55. 
Salvat, G., Coppen, P., Allo, J.C., Fenner, S., Laisney, M.J., Toquin, M.T., Humbert, F. and Colin, P. 1997. Effects of AvGard ${ }^{\mathrm{TM}}$ treatment on the microbiological flora of poultry carcases. Brit. Poultry Sci. 38:489-498.

SAS Institute Inc. 1989. SAS Users Guide: Basics, Version 6.06 edition, Statistical Analysis System Institute Inc., Cary, NC.

Tamblyn, K.C. and Conner, D.E. 1997. Bactericidal activity of organic acids against Salmonella typhimurium attached to broiler chicken skin. J. Food Prot. 60:629-633.

Tamblyn, K. C., Conner, D. E. and Bilgili, S. F. 1997. Utilization of the skin attachment model to determine the antibacterial efficacy of potential carcass treatments. Poultry Sci. 76:13181323.

Thomas, C.J. and McMeekin, T.A. 1984. Effect of water uptake by poultry tissue on contamination by bacteria during immersion in bacterial suspensions. J. Food Prot. 47:398-403.

Wang, W-C., Li., Y., Slavik, M. F., and Xiong, H. 1997. Trisodium phosphate and cetylpyridinium chloride spraying on chicken skin to reduce attached Salmonella typhimurium.

J. Food Prot. 60:992-994.

Wolfson, L. M., Sumner, S. S. and Froning, G. W. 1994. Inhibition of Salmonella typhimurium on poultry by lactoperoxidase system. J. Food Safety 14:53-62.

Xiong, H., Yanbin, L., Slavik, M. F. and Walker, J. T. 1998a. Spraying chicken skin with selected chemicals to reduce attached Salmonella typhimurium. J. Food Prot. 61:272-275.

Xiong, H., Yanbin, L., Slavik, M. F. and Walker, J. T. 1998b. Chemical spray conditions for reducing bacteria on chicken skins. J. Food Sci. 63:699-701.

Yang, Z., Li, Y. and Slavik, M. 1998. Use of antimicrobial spray applied with an inside-outside birdwasher to reduce bacterial contamination on prechilled chicken carcasses. J. Food Prot. 61:829-832.

Zaika, L. L., Scullen, J. O. and Fanelli, J. S. 1997. Growth inhibition of Listeria monocytogenes by sodium polyphosphate as affected by polyvalent metal ions. J. Food Sci. 62:867-872. 
Table 1. Effect of $\mathrm{ZnCl}_{2}$ on "discard" $\mathrm{pH}$ and Salmonella typhimurium attachment to chicken skin in the reversal experiments.

\begin{tabular}{|c|c|c|c|c|c|c|c|c|c|}
\hline \multirow[t]{2}{*}{$\begin{array}{c}\mathrm{ZnCl}_{2} \text { level } \\
(\mathrm{mM})\end{array}$} & \multirow[t]{2}{*}{$\mathrm{pH}$} & \multicolumn{2}{|c|}{ "Firmly" attached cells } & \multicolumn{2}{|c|}{ "Loosely" attached cells } & \multicolumn{2}{|c|}{ "Discarded" cells } & \multicolumn{2}{|c|}{$\begin{array}{l}\text { Scanning electron } \\
\text { microscope data }\end{array}$} \\
\hline & & $\begin{array}{c}\text { Log } \\
\text { CFU/mL }\end{array}$ & $\begin{array}{c}\% \\
\text { reduction }\end{array}$ & $\begin{array}{c}\mathrm{Log} \\
\mathrm{CFU} / \mathrm{mL}\end{array}$ & $\begin{array}{c}\% \\
\text { reduction }\end{array}$ & $\begin{array}{c}\text { Log } \\
\text { CFU/mL }\end{array}$ & $\begin{array}{c}\% \\
\text { reduction }\end{array}$ & $\begin{array}{c}\log \\
\text { Cells } / \mathrm{cm}^{2}\end{array}$ & $\begin{array}{c}\% \\
\text { reduction }\end{array}$ \\
\hline 0 & $6.85^{\mathrm{c}}$ & $3.94^{\mathrm{b}}$ & - & $4.86^{\mathrm{c}}$ & - & $6.80^{\mathrm{b}}$ & - & $5.27^{\mathrm{c}}$ & - \\
\hline 25 & $5.63^{\mathrm{b}}$ & $3.31^{\mathrm{a}}$ & 77 & $4.42^{\mathrm{a}}$ & 64 & $4.61^{\mathrm{a}}$ & 99.4 & $4.76^{\mathrm{bc}}$ & 69 \\
\hline 50 & $5.45^{\mathrm{a}}$ & $2.98^{\mathrm{a}}$ & 89 & $4.44^{\mathrm{a}}$ & 62 & $4.40^{\mathrm{a}}$ & 99.6 & $2.26^{\mathrm{a}}$ & 99.9 \\
\hline Significance & $\mathrm{p}<0.0001$ & $\mathrm{p}<0.01$ & & $\mathrm{p}<0.1$ & & $\mathrm{p}<0.0001$ & & $\mathrm{p}<0.1$ & \\
\hline $\begin{array}{l}\text { Orthogonal } \\
\text { comparisons }\end{array}$ & $\begin{array}{c}\text { A vs B } \\
\text { C vs D } \\
(p<0.05)\end{array}$ & $\begin{array}{c}\text { A vs B } \\
(p<0.05)\end{array}$ & & $\begin{array}{l}\text { A vs B } \\
(p<0.05)\end{array}$ & & $\begin{array}{c}\text { A vs B } \\
(p<0.05)\end{array}$ & & $\begin{array}{l}A \text { vs B } \\
C \text { vs D } \\
(p<0.1)\end{array}$ & \\
\hline
\end{tabular}

A vs $\mathrm{B}=$ without $\mathrm{ZnCl}_{2}$ versus with $\mathrm{ZnCl}_{2}$

$\mathrm{C}$ vs $\mathrm{D}=25 \mathrm{mM} \mathrm{ZnCl}_{2}$ versus $50 \mathrm{mM} \mathrm{ZnCl}_{2}$ 
Figure 1. Schematic diagram of a skin attachment model. 


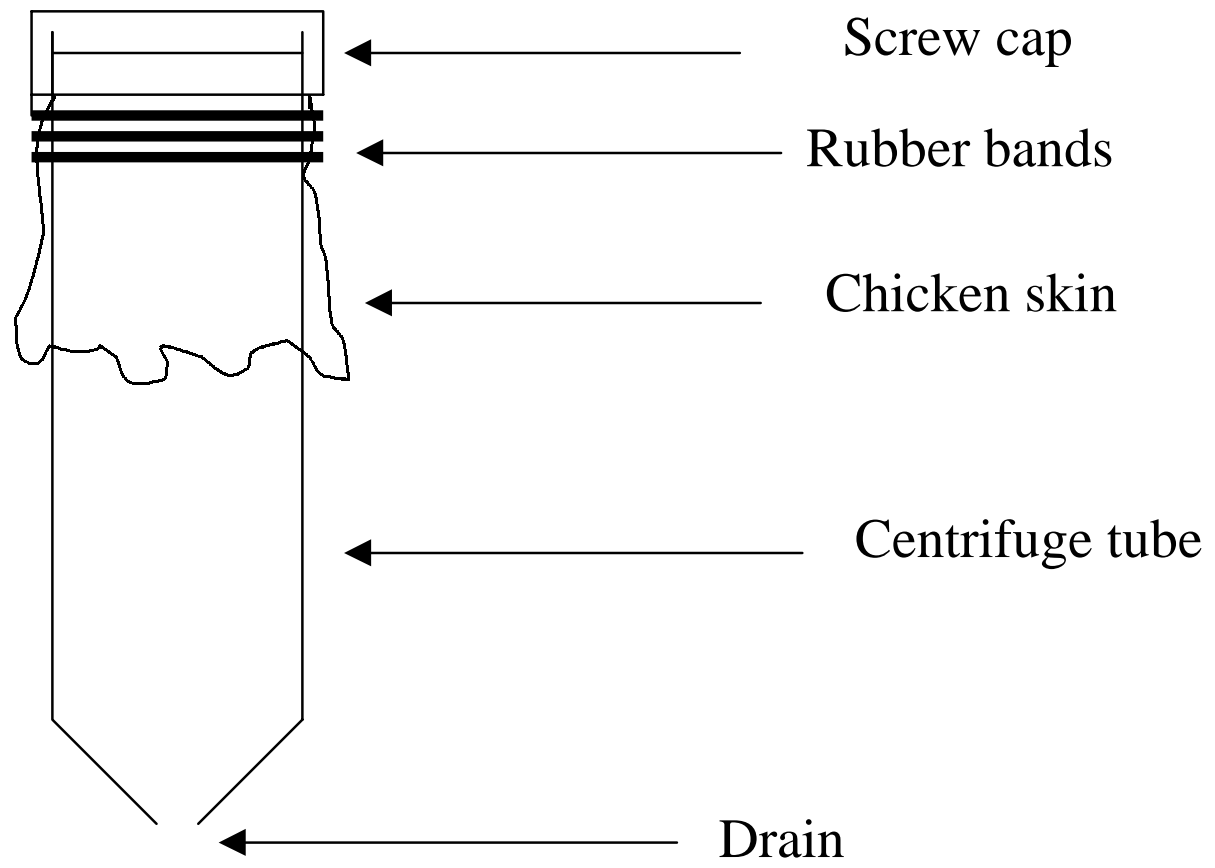


Figure 2. Salmonella typhimurium cell suspension $\left(10^{7} \mathrm{CFU} / \mathrm{mL}\right)$ mixed with (a) control;

(b) $25 \mathrm{mM} \mathrm{ZnCl}_{2}$; and (c) $50 \mathrm{mM} \mathrm{ZnCl} 2$ and held for $15 \mathrm{~min}$ at room temperature $\left(\sim 22^{\circ} \mathrm{C}\right)(1000$ $\mathrm{X})$. 


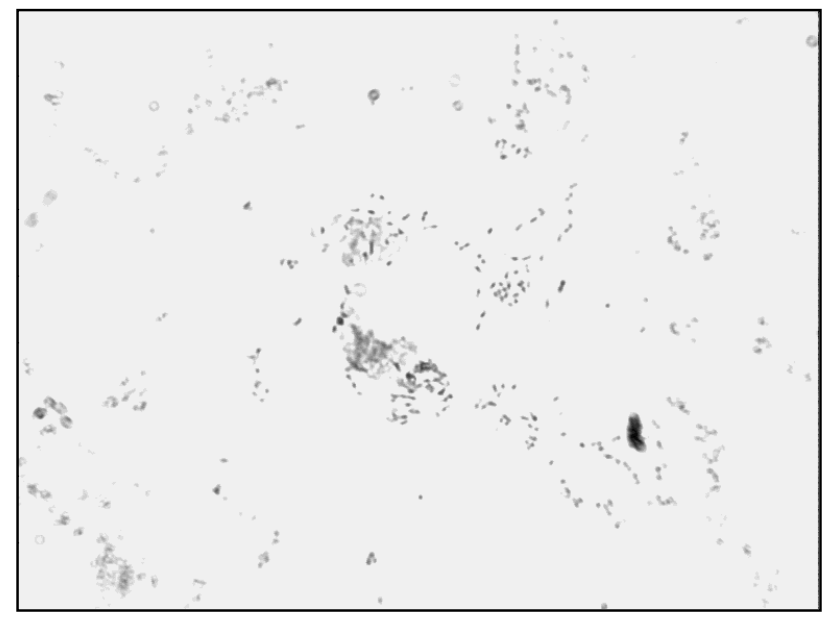

(a)

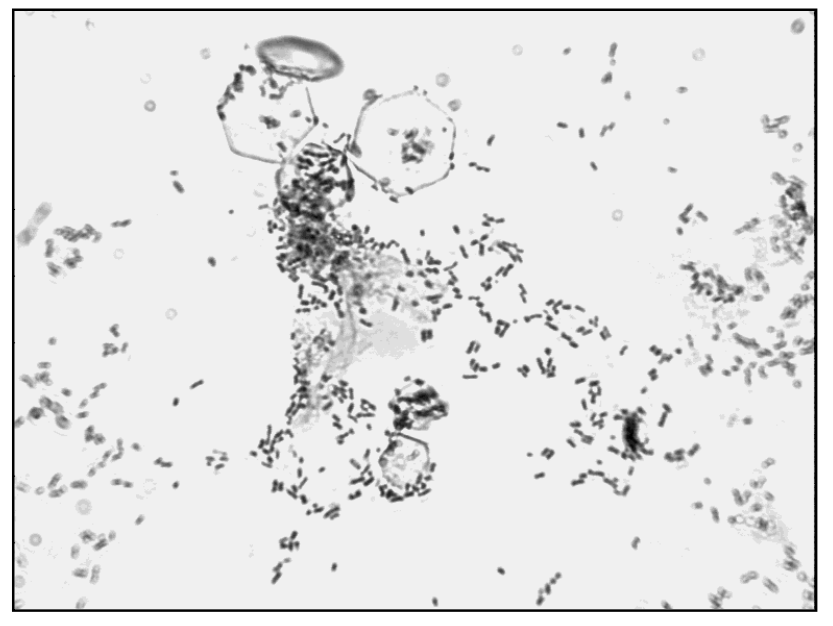

(b)

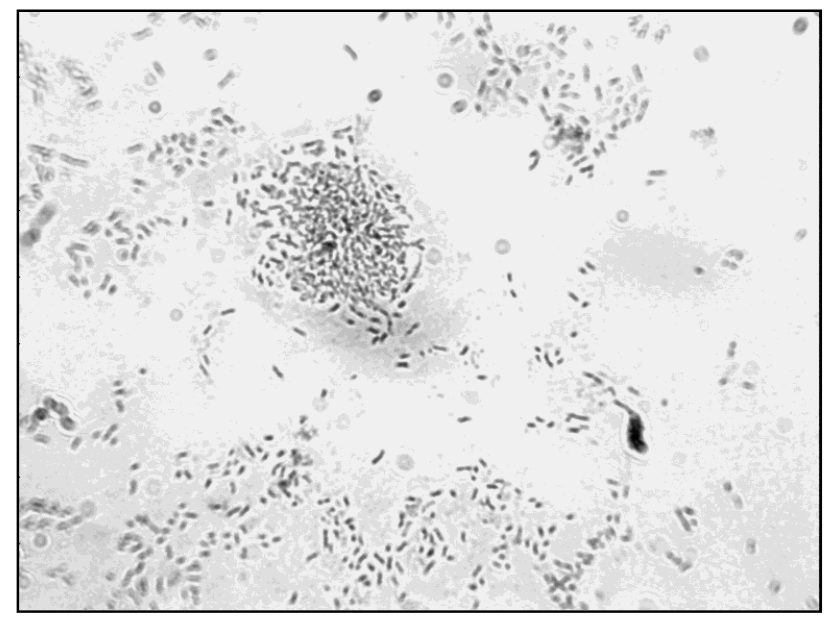

(c) 
Figure 3. Scanning electron micrographs of chicken skin samples from reversal experiments: (a) control, $5 \mathrm{~min}$; (b) $25 \mathrm{mM} \mathrm{ZnCl} 2,5 \mathrm{~min}$; (c) $50 \mathrm{mM} \mathrm{ZnCl}_{2}, 5 \mathrm{~min}$; (d) control, $15 \mathrm{~min}$; (e) 25 $\mathrm{mM} \mathrm{ZnCl} 2,15 \mathrm{~min}$; and (f) $50 \mathrm{mM} \mathrm{ZnCl}_{2}, 15 \min ($ bar $10 \mu)$ 


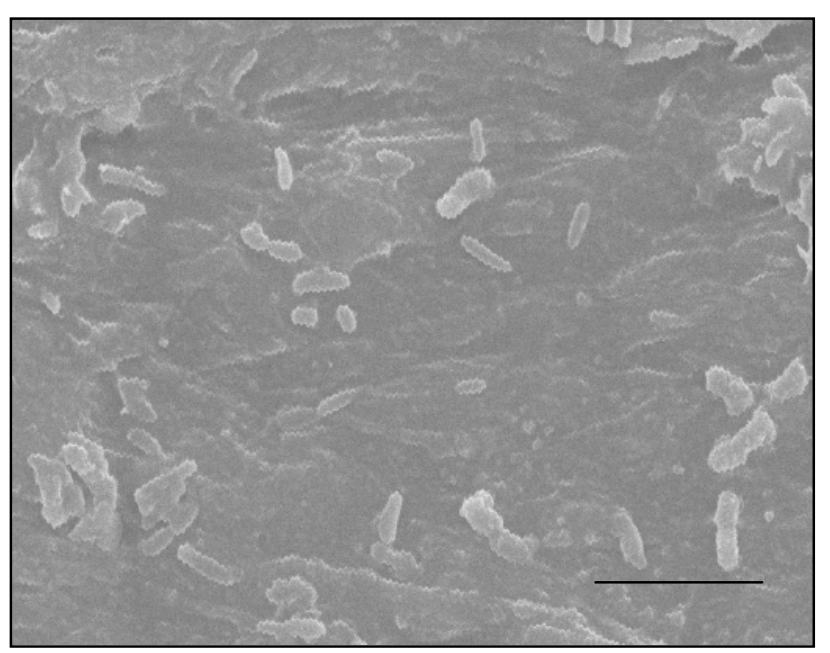

(a)

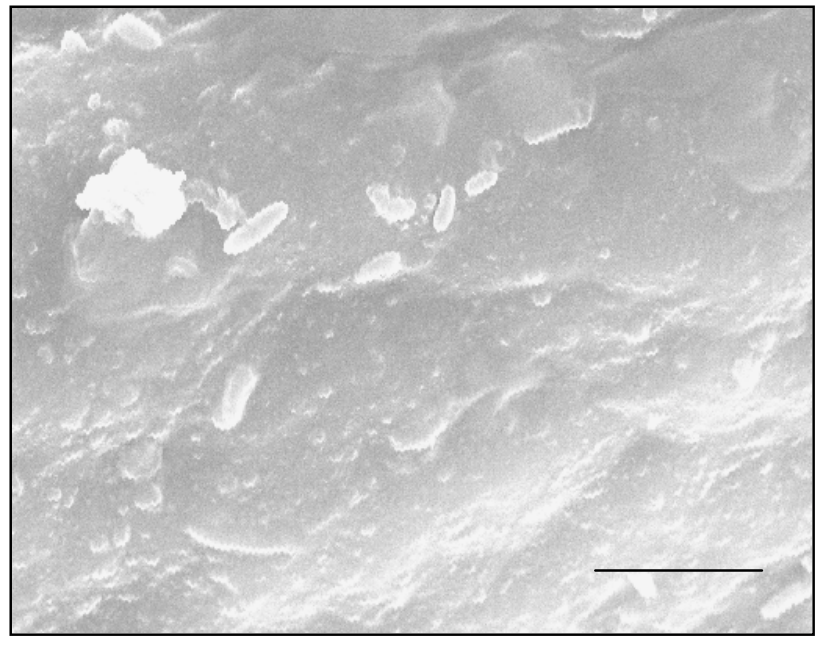

(b)

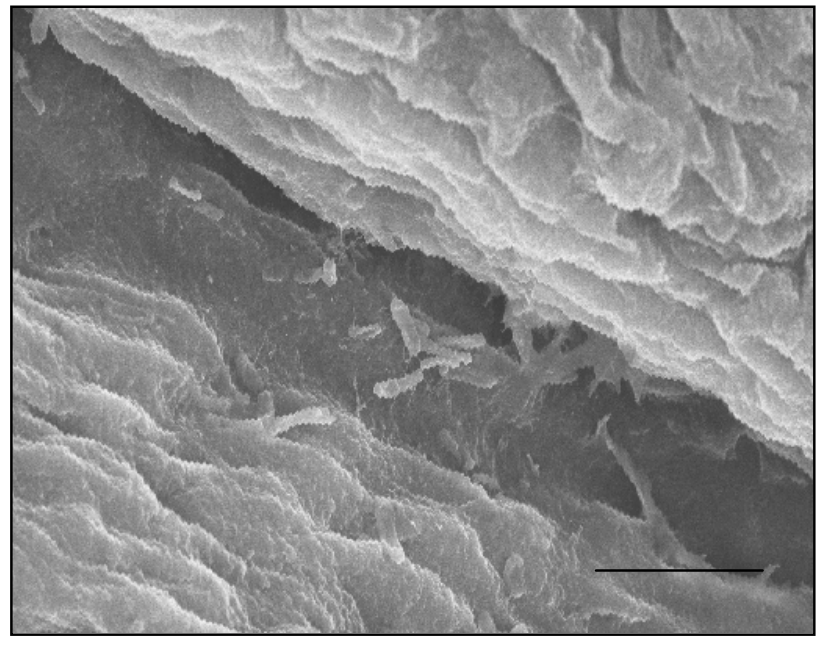

(c) 


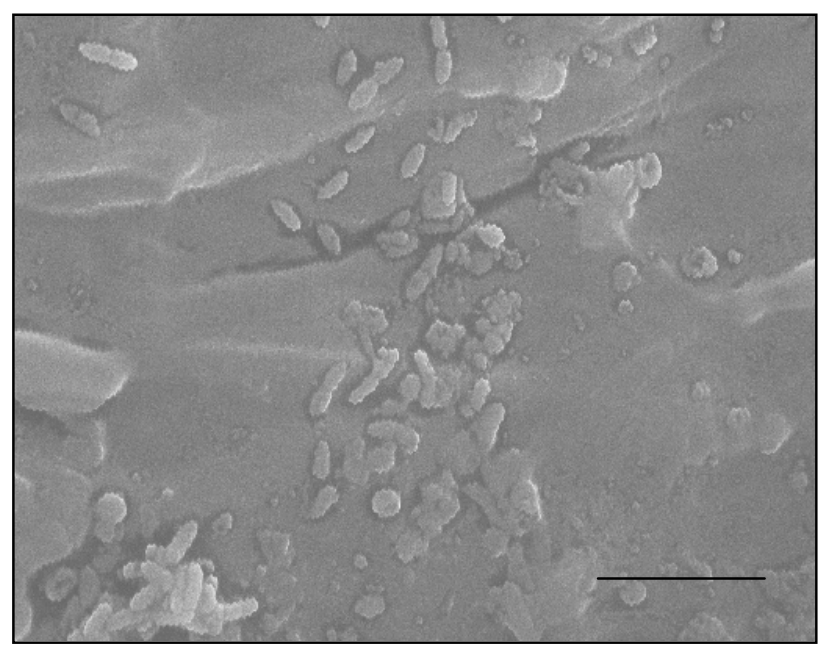

(d)

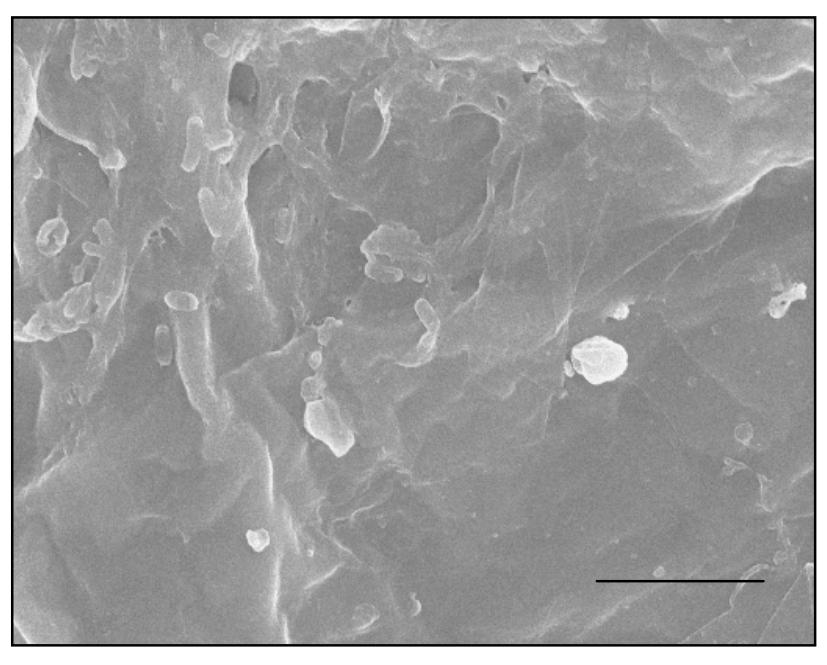

(e)

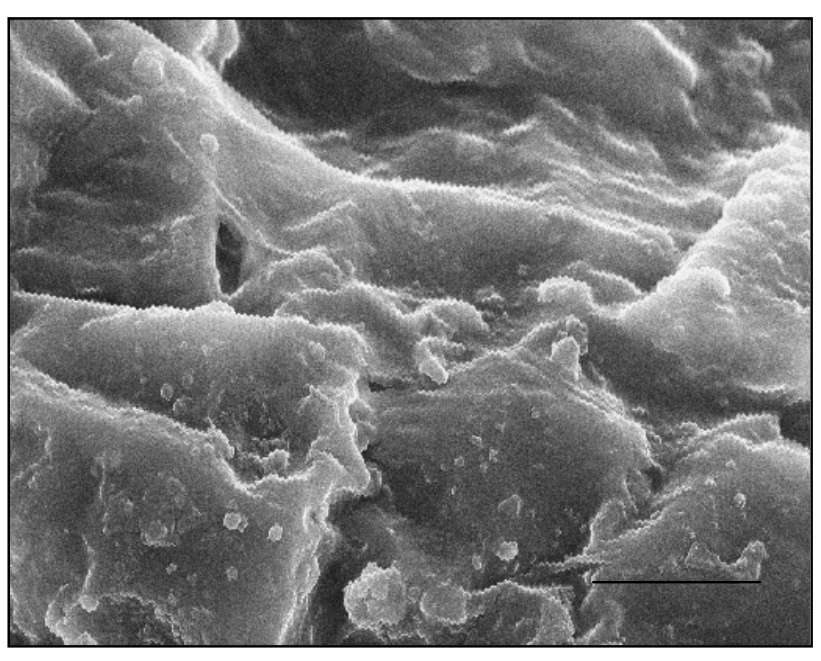

(f) 
Figure 4. Scanning electron micrographs of chicken skin samples from inhibition experiments: (a) control, $5 \mathrm{~min}$; (b) $25 \mathrm{mM} \mathrm{ZnCl}$, $5 \mathrm{~min}$; (c) $50 \mathrm{mM} \mathrm{ZnCl} 2,5 \mathrm{~min}$; (d) control, $15 \mathrm{~min}$; (e) 25 $\mathrm{mM} \mathrm{ZnCl} 2,15 \mathrm{~min}$; and (f) $50 \mathrm{mM} \mathrm{ZnCl}_{2}, 15 \min$ (bar $10 \mu$ ). 


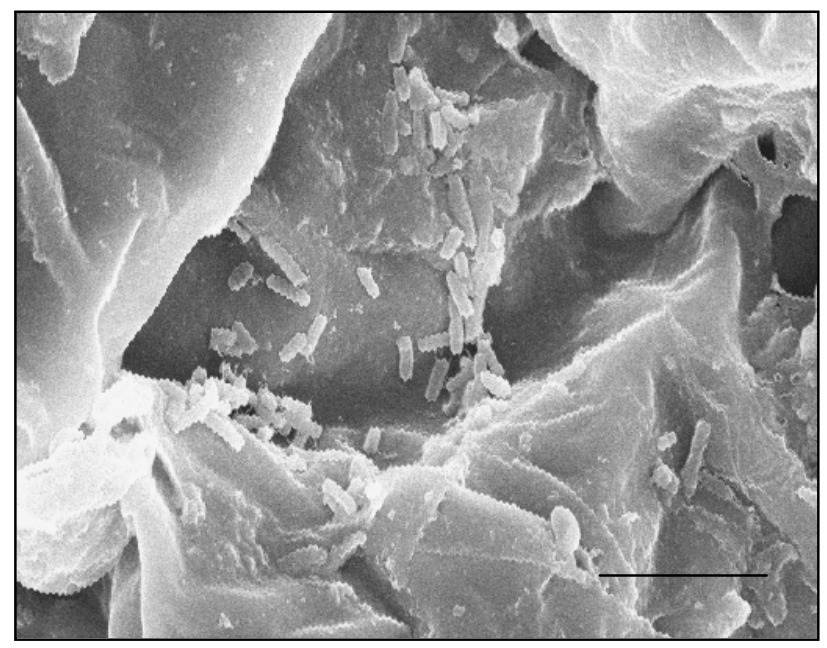

(a)

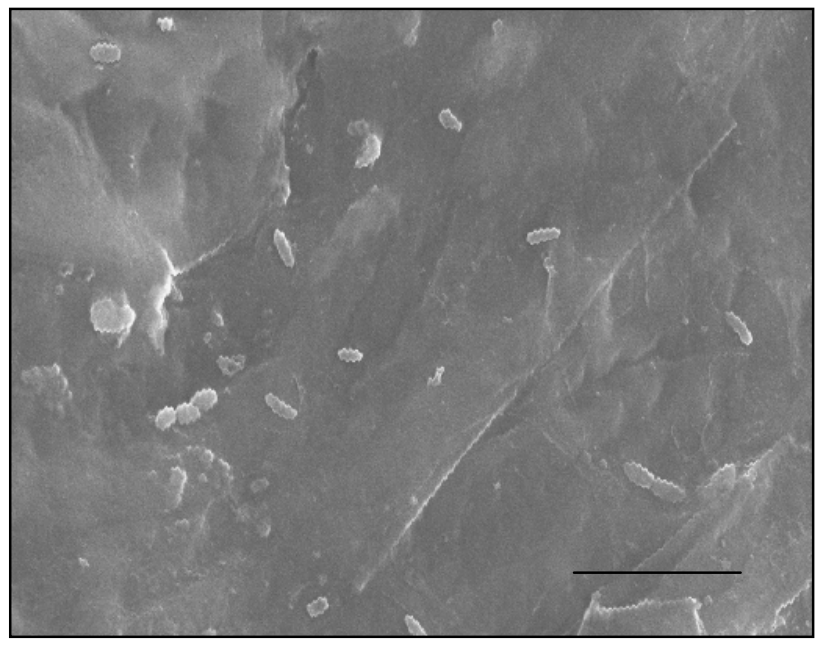

(b)

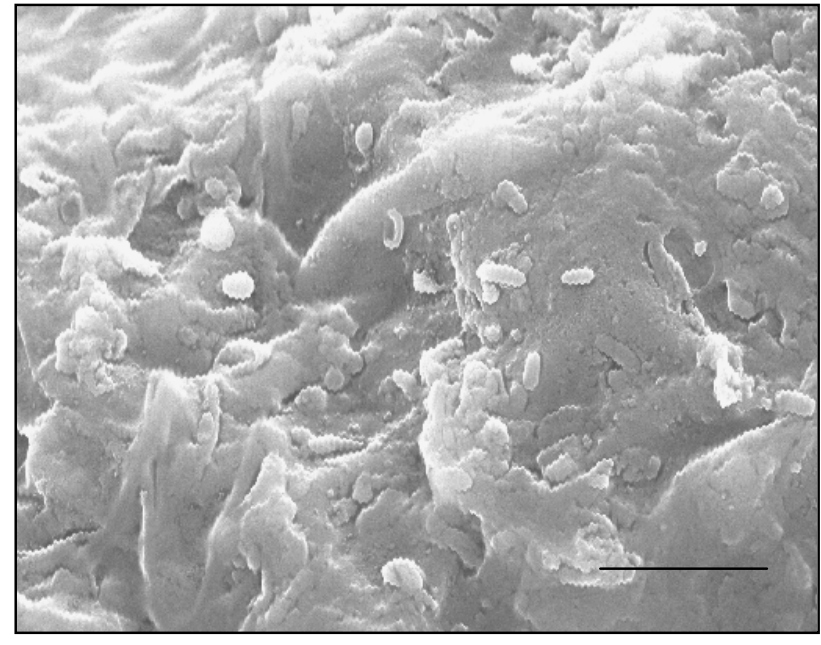

(c) 


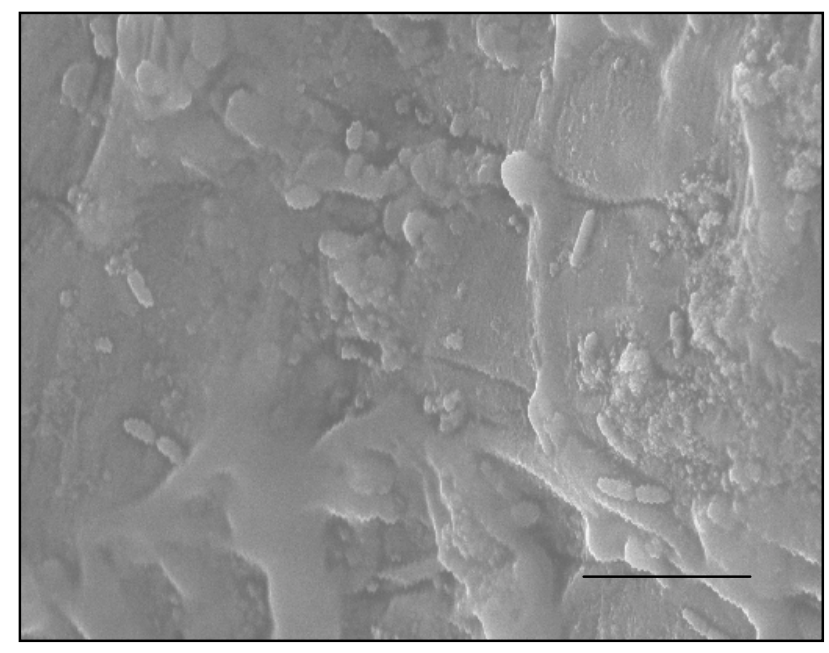

(d)

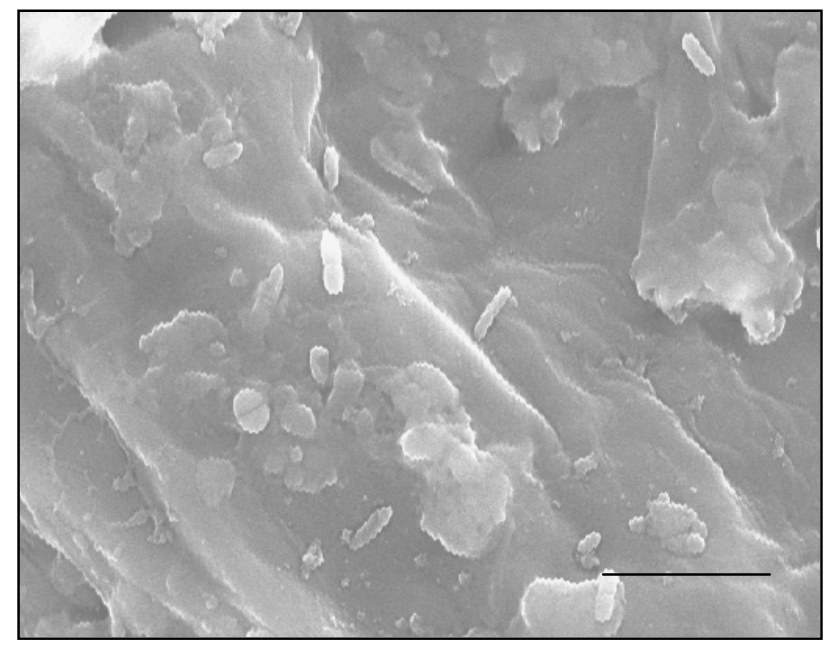

(e)

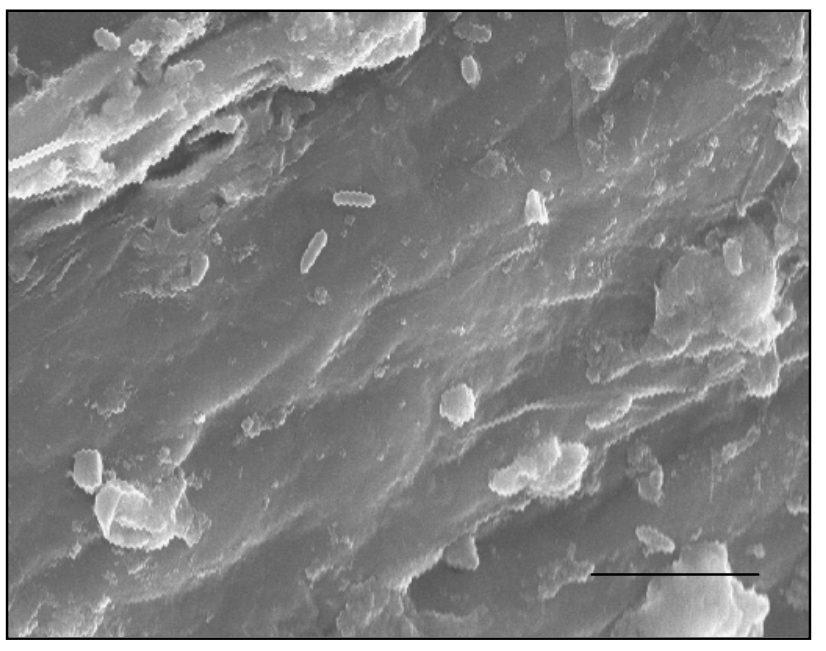

(f) 


\section{APPENDICES}




\section{REVERSAL EXPERIMENT FLOW DIAGRAM}

$50 \mathrm{~mL}$ centrifuge tube with skin attached (2 tubes)

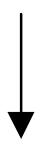

Add $1 \mathrm{~mL}$ of Salmonella culture

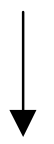

Incubate at room temperature for $30 \mathrm{~min}$

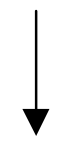

Add $5 \mathrm{~mL}$ (each) control (water), $25 \mathrm{mM}$ or $50 \mathrm{mM} \mathrm{ZnCl}_{2}$ solution

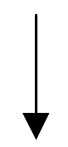

Incubate at room temperature for 5 or $15 \mathrm{~min}$

Discard the treatment solution (drain for 2-3 min) and enumerate Salmonella in "discard"

Enumerate "loose" and "firmly" attached Salmonella on skin (Tube 1) Scanning electron microscopy studies (Tube 2) 


\section{INHIBITION EXPERIMENT FLOW DIAGRAM}

$50 \mathrm{~mL}$ centrifuge tube with skin attached ( 2 tubes)

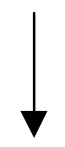

Add $5 \mathrm{~mL}$ (each) control (water), $25 \mathrm{mM}$ or $50 \mathrm{mM} \mathrm{ZnCl}$ solution

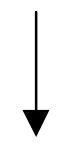

Incubate at room temperature for 5 or $15 \mathrm{~min}$

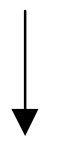

Discard the treatment solutions (drain for 2-3 min)

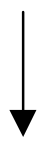

Add $1 \mathrm{~mL}$ of Salmonella culture

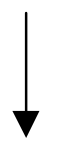

Incubate at room temperature for $30 \mathrm{~min}$

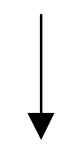

Discard the culture (drain for 2-3 min) and enumerate Salmonella in "discard"

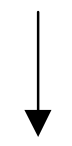

Enumerate "loose" and "firmly" attached Salmonella on skin (Tube 1)

Scanning electron microscopy studies (Tube 2) 


\section{STATISTICAL PROGRAM}

\section{INHIBITION OR REVERSAL EXPERIMENTS}

OPTION LS=80 PAGESIZE=60 NO NUMBER;

TITLE '2X3 FACTORIAL RCB - REVERSAL/INHIBITION EXPERIMENT PLATE COUNT';

DATA MAZE; INPUT REP TIME LEVEL PH LOOSE FIRM DISCARD;

CARDS;

\{PASTE DATA

PROC PRINT;

PROC GLM; CLASSES REP TIME LEVEL;

MODEL PH LOOSE FIRM DISCARD=REP TIME LEVEL TIME*LEVEL;

LSMEANS TIME LEVEL TIME*LEVEL/PDIFF;

CONTRAST 'A VS B' LEVEL 2 -1 -1;

CONTRAST 'C VS D' LEVEL $01-1$;

CONTRAST 'E VS F' TIME $1-1$

TIME*LEVEL 0100 - 0 - 10 ;

CONTRAST 'G VS H' TIME 1 -1

TIME*LEVEL $001000-1$;

CONTRAST 'I VS J' TIME*LEVEL 0 - 1 -1 0 -1 1;

RUN;

\section{SCANNING ELECTRON MICROSCOPE STUDIES}

OPTION LS=80 PAGESIZE=60 NO NUMBER;

TITLE '2X3 FACTORIAL RCB - REVERSAL/INHIBITION SEM EXPERIMENT';

DATA MAZE; INPUT REP TIME LEVEL CFU;

CARDS;

\{PASTE DATA

PROC PRINT;

PROC GLM; CLASSES REP TIME LEVEL;

MODEL CFU=REP TIME LEVEL TIME*LEVEL;

LSMEANS TIME LEVEL TIME*LEVEL/PDIFF;

CONTRAST 'A VS B' LEVEL 2 -1 -1;

CONTRAST 'C VS D' LEVEL $01-1$;

CONTRAST 'E VS F' TIME $1-1$

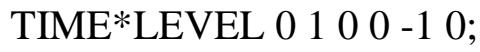

CONTRAST 'G VS H' TIME 1 -1

TIME*LEVEL $0010010-1$;

CONTRAST 'I VS J' TIME*LEVEL 0 - 1 -1 0 -1 1;

RUN; 